Report of Investigations 2015-1

\title{
TSUNAMI INUNDATION MAPS OF ELFIN COVE, GUSTAVUS, AND HOONAH, ALASKA
}

\author{
E.N. Suleimani, D.J. Nicolsky, and R.D. Koehler
}

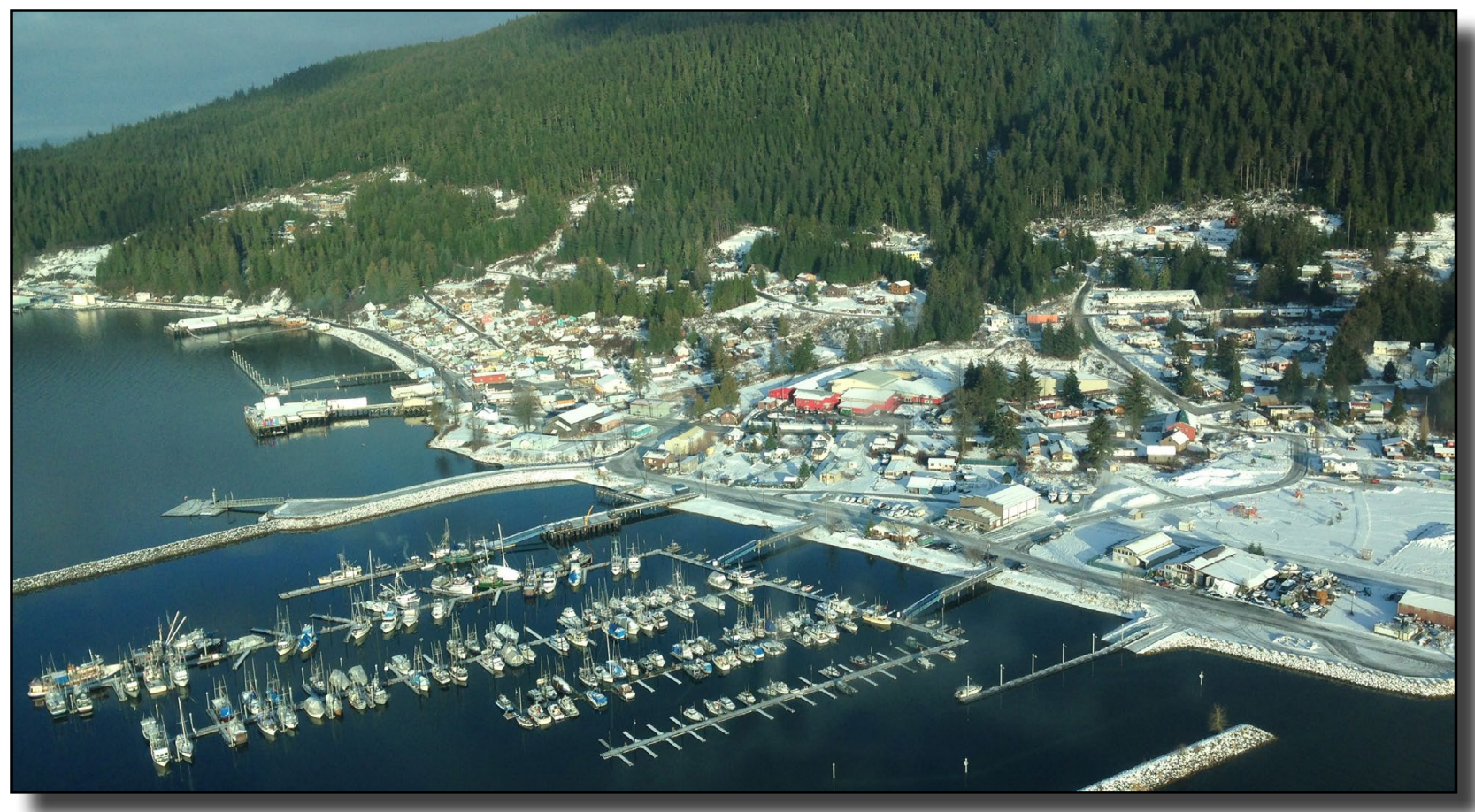

Aerial photograph of the boat harbor and city of Hoonah, Alaska. Photo by Rich Koehler.

Published by

STATE OF ALASKA

DEPARTMENT OF NATURAL RESOURCES

DIVISION OF GEOLOGICAL \& GEOPHYSICAL SURVEYS 



\title{
TSUNAMI INUNDATION MAPS OF ELFIN COVE, GUSTAVUS, AND HOONAH, ALASKA
}

\author{
E.N. Suleimani, D.J. Nicolsky, and R.D. Koehler
}

Report of Investigations 2015-1

State of Alaska

Department of Natural Resources

Division of Geological \& Geophysical Surveys 


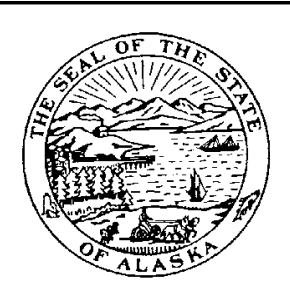

\section{STATE OF ALASKA}

Bill Walker, Governor

\section{DEPARTMENT OF NATURAL RESOURCES}

Mark D. Myers, Ph.D., Commissioner

\section{DIVISION OF GEOLOGICAL \& GEOPHYSICAL SURVEYS}

Steve Masterman, State Geologist and Director

Publications produced by the Division of Geological \& Geophysical Surveys (DGGS) are available for free download from the DGGS website (www.dggs.alaska.gov). Publications on hard-copy or digital media can be examined or purchased in the Fairbanks office:

\section{Alaska Division of Geological \& Geophysical Surveys 3354 College Rd., Fairbanks, Alaska 99709-3707 \\ Phone: (907) 451-5020 Fax (907) 451-5050 \\ dggspubs@alaska.gov \\ www.dggs.alaska.gov}

Alaska State Library

State Office Building, 8th Floor 333 Willoughby Avenue

Juneau, Alaska 99811-0571

Elmer E. Rasmuson Library University of Alaska Fairbanks Fairbanks, Alaska 99775-1005
Alaska Resource Library \& Information Services (ARLIS)

3150 C Street, Suite 100

Anchorage, Alaska 99503-3982

University of Alaska Anchorage Library

3211 Providence Drive

Anchorage, Alaska 99508-4614 


\section{CONTENTS}

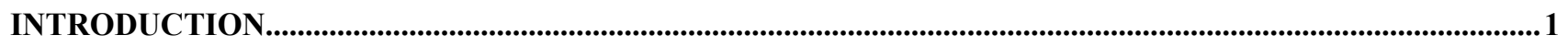

PROJECT BACKGROUND: REGIONAL AND HISTORICAL CONTEXT ............................................................2

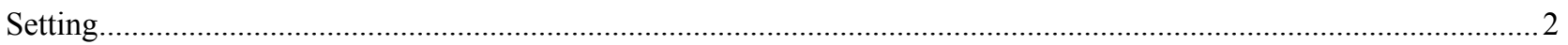

Elfin Cove

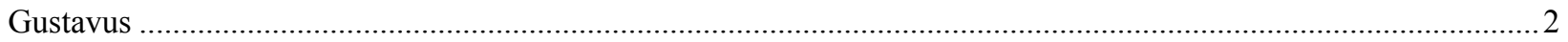

Hoonah .

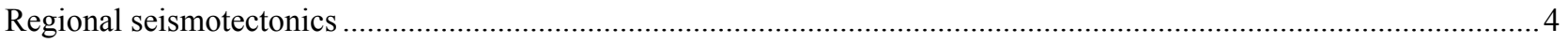

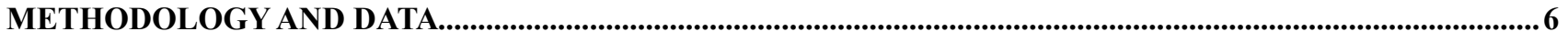

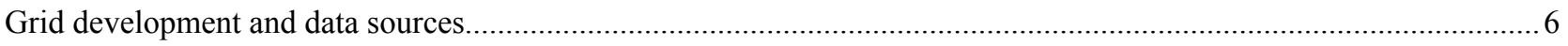

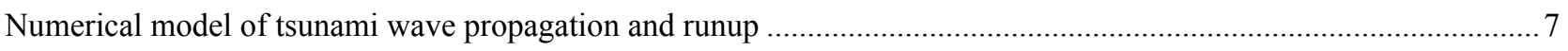

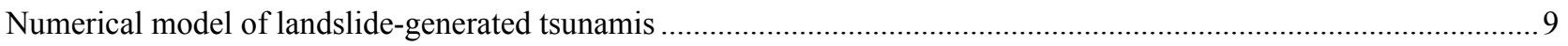

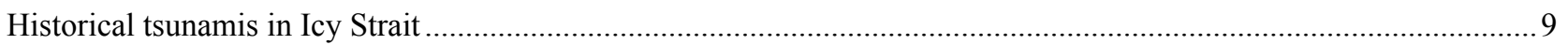

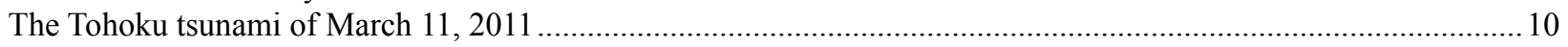

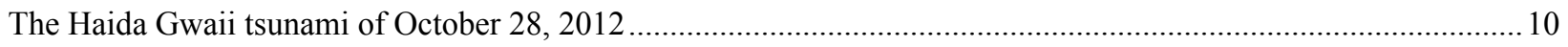

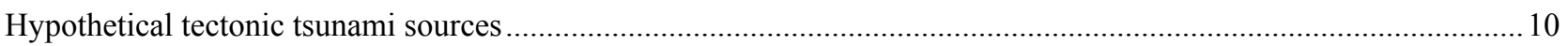

Source models of hypothetical tsunamigenic earthquakes in the Gulf of Alaska..................................................... 10

Scenario 1. Multi-segment event: The PWS and KP segments of the 1964 rupture, and the YY segment........... 10

Scenario 2. Multi-segment event: The PWS, KP, and KI segments with Tohoku-type slip distribution in the

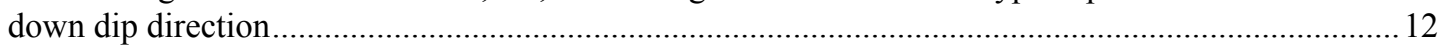

Source models of hypothetical Tohoku-type events in the Gulf of Alaska ............................................................. 12

Scenario 3. $\mathrm{M}_{\mathrm{w}} 9.0$ event in the Gulf of Alaska region, variable slip along strike. ............................................. 16

Scenario 4. $\mathrm{M}_{\mathrm{w}} 9.0$ event in the Gulf of Alaska region, uniform slip along strike............................................ 16

Source models of hypothetical tsunamigenic earthquakes in the Alaska Peninsula segment of the Alaska-Aleutian

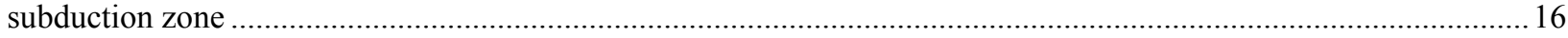

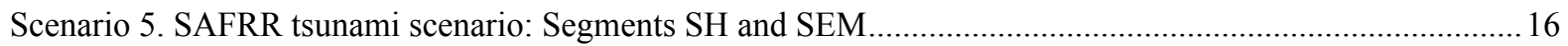

Scenario 6. Multi-segment event: SEM, SH, UN, and FOX segments .......................................................... 16

Seismic source model of a hypothetical tsunamigenic earthquake in the Yakutat Block............................................ 16

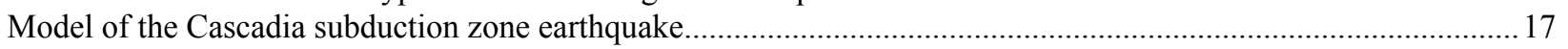

Scenario 7. Rupture of the Cascadia subduction zone, including portions of the margin along the British

Columbia, Washington, Oregon, and northern California shore …….............................................. 17

Source models of a hypothetical tsunamigenic earthquake in southeastern Alaska ..................................................... 18

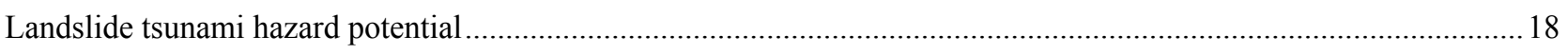

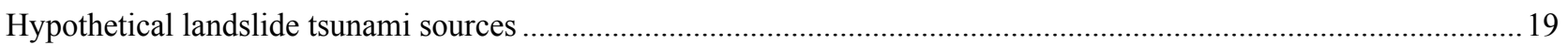

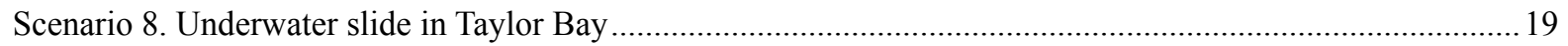

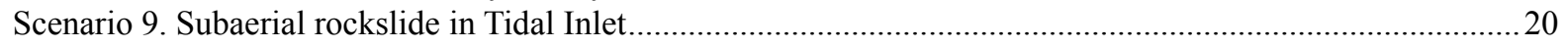

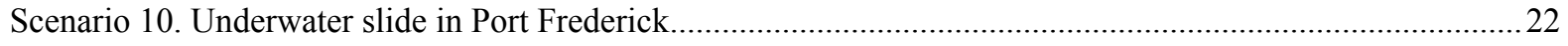

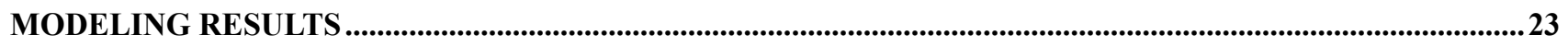

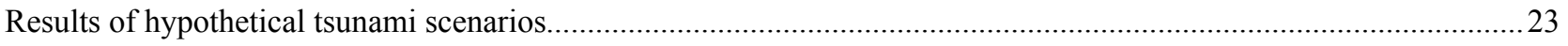

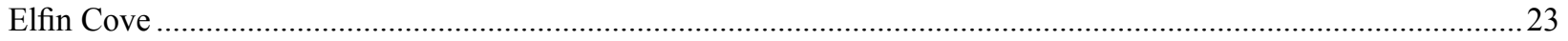

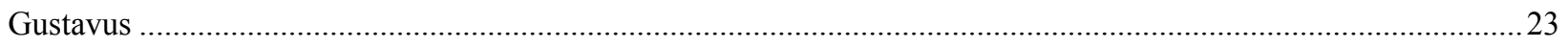

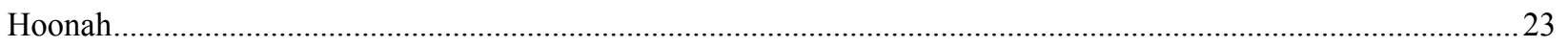

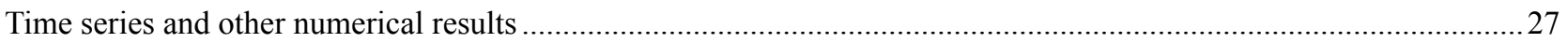

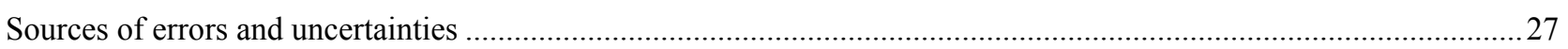

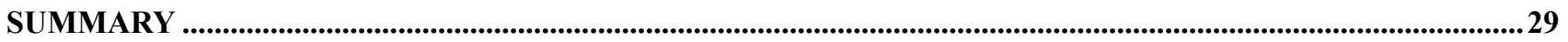

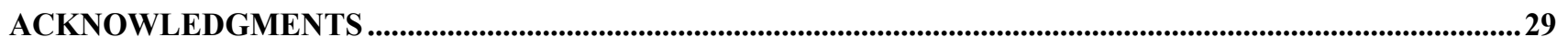

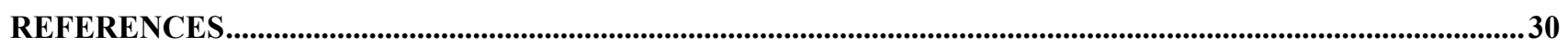




\section{FIGURES}

Figure 1. Map of south-central and southeastern Alaska, showing rupture areas of the major earthquakes ..... 1

2. Location map of Elfin Cove, Gustavus, Hoonah, and other communities in the Icy Strait region of southeastern Alaska.

3. Photographs of docks in Elfin Cove, an aerial view of Gustavus, and a view of the Hoonah shoreline ............ 4

4. Earthquakes in southeastern Alaska, from the Alaska Earthquake Center catalog......................................5

5. Telescoping embedded bathymetry/topography grids for numerical modeling of tsunami propagation and runup

6. Vertical coseismic deformations for the source models of the 2011 Tohoku tsunami

7. The recorded sea level at Elfin Cove during the 2011 Tohoku tsunami, compared with the time series calculated for the source functions shown in figure 6 .

8. Vertical coseismic deformations corresponding to the four different slip models of the October 28, 2012, Haida Gwaii earthquake.

9. The recorded sea level at Elfin Cove during the 2012 Haida Gwaii tsunami, compared with the time series calculated for four source functions shown in figure 8 ......

10. Map of Alaska with rupture zone of the 1964 Great Alaska Earthquake and segments of the AlaskaAleutian megathrust

11. Vertical coseismic deformations corresponding to scenarios 1-7

12. View of the Gulf of Alaska, showing major tectonic elements and communities of Elfin Cove, Gustavus, and Hoonah

13. Illustration showing initial thickness of the Taylor Bay slide (scenario 8).....

14. Photographs showing location of the potential slide on the northern shore of Tidal Inlet, and a view of the slide from Tidal Inlet.

15. Illustration showing initial thickness of the slide in Port Frederick, off the delta of Humpback Creek (scenario 10).

16. Maximum composite potential inundation extent for all scenarios, and maximum composite flow depths over dry land in Elfin Cove.

17. Maximum composite wave height for tectonic scenarios at Elfin Cove.................................................25

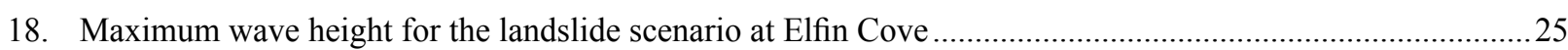

19. Maximum composite potential inundation extent for all scenarios, and the maximum composite flow

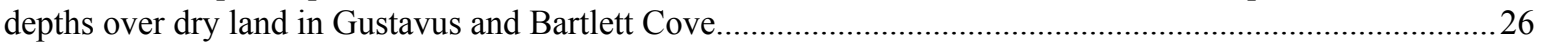

20. Maximum composite wave height for tectonic scenarios at Gustavus ..................................................27

21. Maximum composite potential inundation extent for all scenarios, and the maximum composite flow

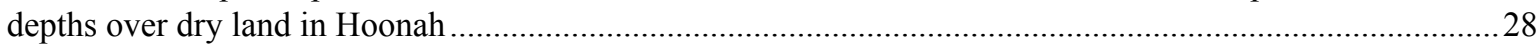

22. Maximum composite wave height for tectonic scenarios at Hoonah ....................................................29

23. Maximum wave height for the landslide scenario at Hoonah.................................................................29

\section{TABLES}

Table 1. Nested grids used to compute tsunami wave propagation in Elfin Cove, Gustavus, and Hoonah .................... 7

2. Hypothetical tectonic scenarios used to model tsunami runup in Elfin Cove, Gustavus, and Hoonah ............. 12

3. Hypothetical landslide scenarios used to model tsunami runup in Elfin Cove, Gustavus, and Hoonah ........... 19

4. Figures in appendices A-C that display locations of time series points and calculated time series for Elfin Cove, Gustavus, and Hoonah..... 


\section{APPENDICES}

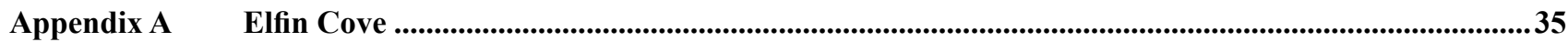

Table A-1. The longitude and latitude locations of the time series points...........................................................35

A-2. Calculated maximum sea level for all tectonic scenarios at locations listed in table A-1 ......................35

A-3. Calculated maximum water current velocities for all tectonic scenarios at locations listed in

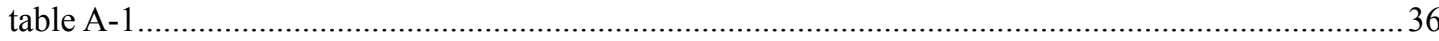

Figure A-1. Locations of time-series points in the Elfin Cove high-resolution grid.................................................37

A-2. Locations of time-series points in the grid that covers Glacier Bay and Icy Strait .................................38

A-3. Time series of the water level and velocity at Elfin Cove for scenarios $1-4$ at the locations shown in figure A-1

A-4. Time series of the water level and velocity at Elfin Cove for scenarios 5-7 at the locations shown in figure A-1

A-5. Time series of the water level and velocity for scenario 8 (underwater slide in Taylor Bay) at the locations shown in figures A-1 and A-2.

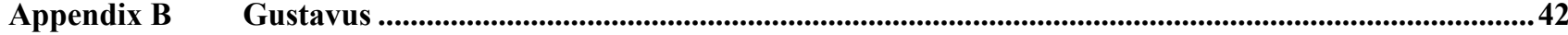

Table $\quad$ B-1. The longitude and latitude locations of the time series points............................................................... 42

B-2. Calculated maximum sea level for all tectonic scenarios at locations listed in table B-1 .....................42

B-3. Calculated maximum water current velocities for all tectonic scenarios at locations listed in table B-1

Figure B-1. Locations of time-series points in the Gustavus high-resolution grid

B-2. Time series of the water level and velocity at Gustavus for scenarios 1-4 at the locations shown in figure B-1

B-3. Time series of the water level and velocity at Gustavus for scenarios 5-7 at the locations shown in figure B-1

B-4. Time series of the water level and velocity for scenario 9 (subaerial rockslide in Tidal Inlet) at the locations shown in figures B-1 and A-2.

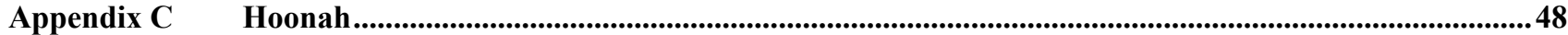

Table C-1. The longitude and latitude locations of the time series points................................................................48

$\mathrm{C}-2$. Calculated maximum sea level for all tectonic scenarios at locations listed in table $\mathrm{C}-1$......................48

C-3. Calculated maximum water current velocities for all tectonic scenarios at locations listed in table $\mathrm{C}-1$

Figure C-1. Locations of time-series points in the Hoonah high-resolution grid ....................................................50

C-2. Time series of the water level and velocity at Hoonah for scenarios 1-4 at the locations shown in figure $\mathrm{C}-1$

C-3. Time series of the water level and velocity at Hoonah for scenarios 5-7 at the locations shown in figure $\mathrm{C}-1$

C-4. Time series of the water level and velocity for scenario 10 at the locations shown in figure C-1 ........53

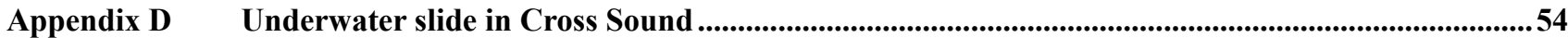

Figure D-1. Source mechanism and epicenter of the $\mathrm{M}_{\mathrm{W}} 6.1$ July 25, 2014, earthquake in southeastern Alaska

D-2. Location of the Alaska Communications fiber cable cut in Cross Sound in relation to the community of Elfin Cove and the hypothetical landslide scenario in Taylor Bay 



\title{
TSUNAMI INUNDATION MAPS OF ELFIN COVE, GUSTAVUS, AND HOONAH, ALASKA
}

\author{
E.N. Suleimani ${ }^{1}$, D.J. Nicolsky ${ }^{1}$, and R.D. Koehler ${ }^{2}$
}

\begin{abstract}
In this report, we evaluate potential tsunami hazards for southeastern Alaska communities of Elfin Cove, Gustavus, and Hoonah and numerically model the extent of inundation from tsunami waves generated by tectonic and landslide sources. We perform numerical modeling of historic tsunami events, such as the tsunami triggered by the $1964 \mathrm{Great}$ Alaska Earthquake, and the tsunami waves generated by the recent 2011 Tohoku and 2012 Haida Gwaii earthquakes. Hypothetical tsunami scenarios include variations of the extended 1964 rupture, megathrust earthquakes in the Prince William Sound and Alaska Peninsula regions, and a Cascadia megathrust earthquake. Local underwater landslide events in Taylor Bay and Port Frederick, and a rockslide in Tidal Inlet are also considered as possible tsunamigenic scenarios. Numerical modeling results, combined with historical observations in the region, are intended to provide guidance to local emergency management in tsunami hazard assessment, evacuation planning, and public education for the reduction of future tsunami risk.
\end{abstract}

\section{INTRODUCTION}

Subduction of the Pacific plate beneath the North American plate has caused numerous great earthquakes and has the potential to generate future major earthquakes and tsunamis in Alaska. The Alaska-Aleutian subduction zone is the most seismically active tsunamigenic fault zone in the United States (fig. 1). Several historical tsunamis generated by earthquakes in this region have resulted in widespread damage and loss of life after traveling for hours across the Pacific and impacting exposed coastal locations. However, tsunamis originating in the vicinity of the Alaska Peninsula, Aleutian Islands, and the Gulf of Alaska are considered to be a near-field hazard for Alaska, which means that they can reach Alaska's coastal communities in less than 3 hours, and more likely within minutes of the earthquake. Saving lives

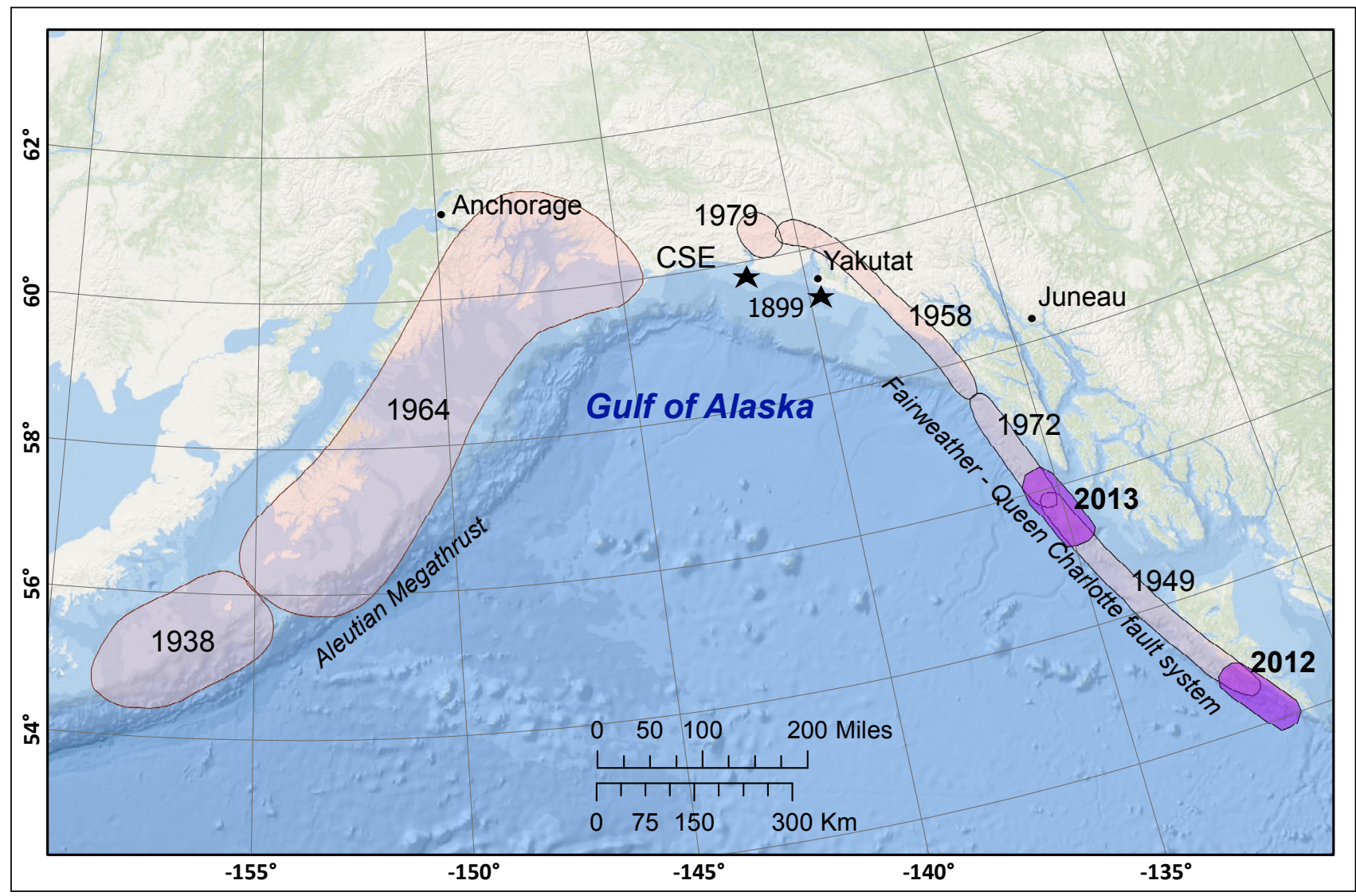

Figure 1. Map of south-central and southeastern Alaska with rupture areas of the major earthquakes shaded in lavender. Black stars indicate epicenters of two September 1899 earthquakes.

\footnotetext{
${ }^{1}$ Alaska Earthquake Center, Geophysical Institute, University of Alaska, P.O. Box 757320, Fairbanks, AK 99775-7320;

elena@gi.alaska.edu; djnicolsky@alaska.edu

${ }^{2}$ Alaska Division of Geological \& Geophysical Surveys, 3354 College Rd., Fairbanks, AK 99709-3707; richard.koehler@alaska.gov
} 
and property depends on how well a community is prepared, which makes it essential to estimate the potential flooding of the coastal zone in the event of a local or distant tsunami.

On March 27, 1964, the largest earthquake ever recorded in North America struck south-central Alaska. This $\mathrm{M}_{\mathrm{W}} 9.2$ megathrust earthquake generated the most destructive tsunami in recorded Alaska history and, farther south, impacted the west coasts of the United States and Canada. In addition to the major tectonic tsunami, which was generated by an ocean floor displacement between the trench and the coastline, more than 20 local tsunamis were generated by landslides in bays and fjords of coastal Alaska, as well as in some interior lakes. Local tsunamis arrived almost immediately after shaking was felt, leaving no time for warning or evacuation. Of the 131 fatalities associated with this earthquake, 122 were caused by tsunami waves. Local tsunamis caused most of the damage and accounted for 76 percent of tsunami fatalities in Alaska (Lander, 1996).

The production of tsunami evacuation maps for a community consists of several stages. First, we develop credible hypothetical tsunami scenarios on the basis of relevant local and distant sources and tsunami generation mechanisms. We characterize tsunami sources using the level of detail necessary to describe the essential characteristics of the wave, with local tsunami sources having more detailed characterization. Next, we perform model simulations for each of these scenarios. The results are then compared with historical tsunami observations, if such data exist. Finally, we develop a "worst case" inundation line that encompasses the maximum extent of flooding based on model simulation of all source scenarios and historical observations. The "worst case" inundation line becomes a basis for local tsunami hazard planning and for developing evacuation maps.

The tsunami inundation maps of Elfin Cove, Gustavus, and Hoonah described in this report represent the results of the continuous combined effort of state and federal agencies to produce inundation maps for many Alaska coastal communities. In this report we generally provide both metric and imperial units of measure. If it is necessary to quote some existing data, we state the data in the original and metric units of measure. Recall that one inch ( $1 \mathrm{in}$ ) is approximately 2.54 centimeters $(2.54 \mathrm{~cm})$, one foot $(1 \mathrm{ft})$ is approximately 0.305 meters $(0.305 \mathrm{~m})$, and one mile $(1 \mathrm{mi})$ is approximately 1.609 kilometers $(1.609 \mathrm{~km})$.

\section{PROJECT BACKGROUND: REGIONAL AND HISTORICAL CONTEXT}

\section{SETTING Elfin Cove}

The small community of Elfin Cove, with a population of 32 in the 2000 Census, lies on the northern shore of Chichagof Island in southeastern Alaska $\left(58^{\circ} 11^{\prime} 56^{\prime \prime} \mathrm{N}, 136^{\circ} 21^{\prime} 19^{\prime \prime} \mathrm{W}\right)$. Accessible only by small seaplane or boat, the community is approximately $110 \mathrm{~km}(70 \mathrm{mi})$ by air and $135 \mathrm{~km}(85 \mathrm{mi})$ by boat west of Juneau (figs. 2, 3a). The area's maritime climate is characterized by cool summers and mild winters, ranging from $52^{\circ}$ to $63^{\circ} \mathrm{F}$ in summer and $26^{\circ}$ to $39^{\circ} \mathrm{F}$ in winter.
According to the Alaska Department of Commerce, Community, and Economic Development's Division of Community and Regional Affairs (DCCED/DCRA), this protected, flask-shaped harbor was originally called "Gunkhole" by fishermen anchoring here. Its safe anchorage and proximity to the Fairweather fishing grounds made this a natural spot for fish buyers and suppliers. Ernie Swanson built a store, restaurant, and dock here in the 1920s. His wife, Ruth, applied for a post office in 1935 and gave it the new name of Elfin Cove. John Lowell, another fish buyer, arrived in the 1940s and built a second dock, warehouse, store, and restaurant. According to locals, the Tlingits who visited the harbor would not stay over winter because of the "evil spirits" there. The area is a popular destination for sport fishing. Elfin Cove is the home of a state-owned seaplane base and provides moorage for 25 marine vessels. Skiffs are the primary means of local transportation. The state ferry lands at nearby Pelican.

\section{Gustavus}

The small community of Gustavus (pronounced gus-TAYvuhs), population 489, lies on the north shore of Icy Passage at the mouth of the Salmon River in the St. Elias Mountains $\left(58^{\circ} 24^{\prime} 48^{\prime \prime} \mathrm{N}, 135^{\circ} 44^{\prime} 13^{\prime \prime} \mathrm{W}\right), 77 \mathrm{~km}(48 \mathrm{mi})$ northwest of Juneau (figs. 2, 3b). It is surrounded by 3.3 million acres of Glacier Bay National Park and Preserve on three sides and the waters of Icy Passage on the south. The area's maritime climate is characterized by cool summers and mild winters.

According to DCCED/DCRA, when Capt. George Vancouver sailed through Icy Strait in 1794, Glacier Bay was completely covered by the Grand Pacific Glacier. Over the next century, the glacier retreated some $65 \mathrm{~km}$ (40 mi), and a spruce-hemlock forest began to develop. By 1916, the glacier had retreated $105 \mathrm{~km}(65 \mathrm{mi})$ from the position first observed by Vancouver. Gustavus, which began as an agricultural homestead in 1914, lies on a flat, glacial outwash plain and used to be known as Strawberry Point, named for the bounty of sweet strawberries that grew wild across the flats. The name Strawberry Point was changed to Gustavus (taken from the name of the point at the mouth of Glacier Bay) by the new local post office in 1925. Glacier Bay National Monument, including Gustavus, was established by President Calvin Coolidge in 1925. After many appeals, the original homesteaders were able to keep their land, and Gustavus was excluded from the monument.

Gustavus is a community with a number of seasonal-use homes for Juneau residents. The nearby Glacier Bay National Park is a major recreation and tourist attraction in Southeast. Many of the residents who have relocated here chose Gustavus for the lifestyle, nearness to natural resources, the beauty of the area, and subsistence activities.

Gustavus has a state-owned airport with jet capability. Alaska Airlines operates daily flights in the summer, and many small planes, corporate jets, and air taxi services use the airport. Air traffic is relatively high during peak summer months, and cruise ships include the bay in their itinerary. Small boats and small ferry boats regularly dock in Gustavus in the summer. Tours are available from Bartlett Cove, Gustavus, and Juneau. Because of the large number of tourists who 


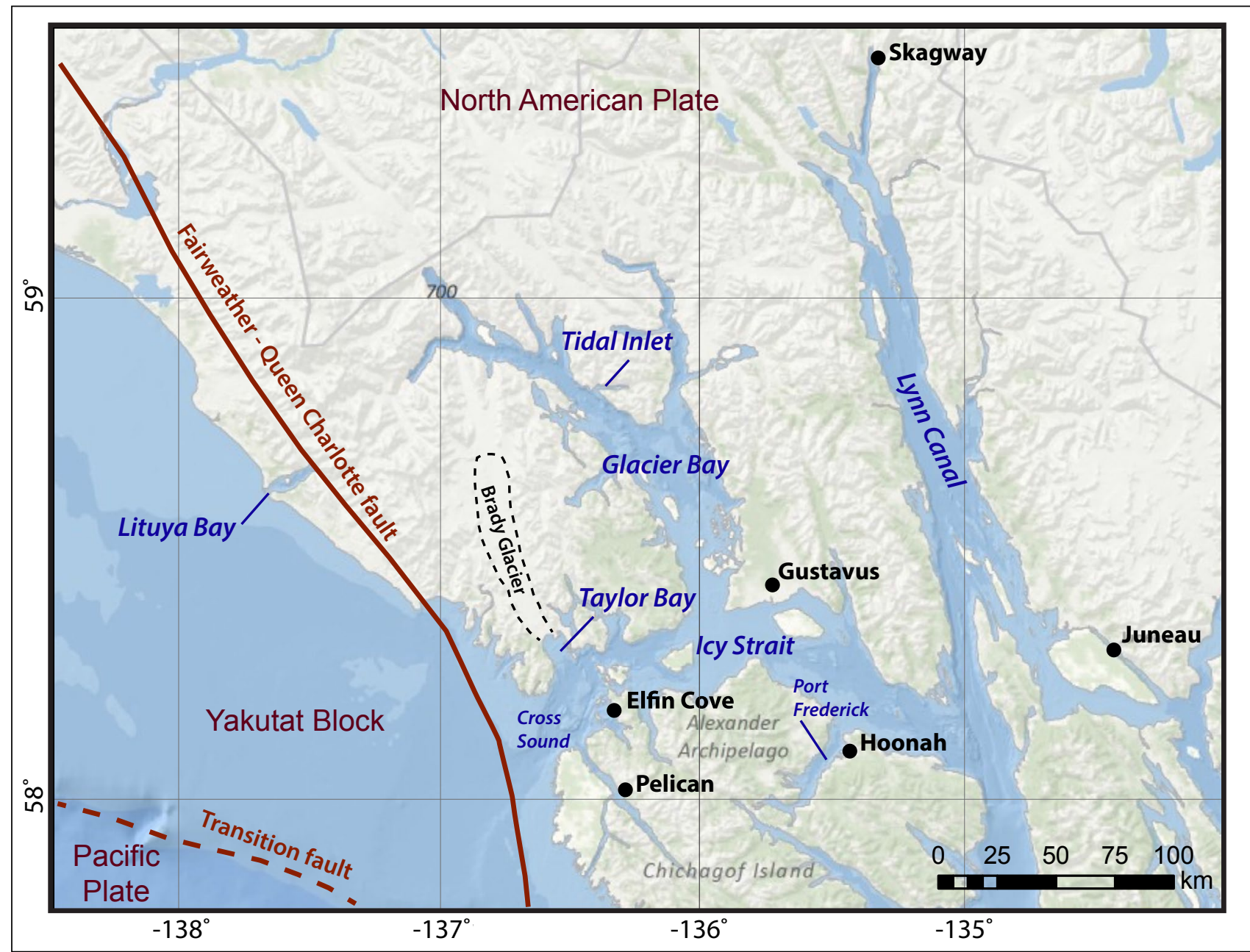

Figure 2. Location of Elfin Cove, Gustavus, Hoonah, and other communities in the Icy Strait region of southeastern Alaska.

arrive by boat or plane in the area, Gustavus is considered the gateway to Glacier Bay National Park.

\section{Hoonah}

The community of Hoonah (pronounced HOO-nah), with a population of 860 in the 2000 Census, is a Tlingit community on the northeastern shore of Chichagof Island $\left(58^{\circ} 6^{\prime} 36^{\prime \prime} \mathrm{N}, 136^{\circ} 26^{\prime} 37^{\prime \prime} \mathrm{W}\right)$. Hoonah is $50 \mathrm{~km}(30 \mathrm{mi})$ west of Juneau, across Alaska's Inland Passage, or $65 \mathrm{~km}(40 \mathrm{mi})$ by air (figs. 2, 3c; DCCED/DCRA). Hoonah is the only firstclass city on Chichagof Island, the fifth largest island in the United States. During the summer months the population can swell to 1,300, depending on fishing, boating, hiking, and hunting conditions.

The maritime climate of the region is characterized by cool summers and mild winters. The local airport can be closed 20 to 30 days a year due to poor weather-usually low visibility during foggy periods in spring and fall. Hoonah is dependent on air and water transportation for movement of small freight and passengers. A state ferry terminal and airport serve the community.

Hoonah is the principal village for the Huna, a Tlingit tribe that has occupied the Glacier Bay/Icy Strait area since prehistory ("Visit Hoonah" website, 2013). Hoonah means "where the north wind doesn't blow" in the Tlingit language. A post office was established in the village in 1901 and a large salmon cannery, the Hoonah Packing Company, was built in 1912. In 1944 a fire destroyed much of the town along with many irreplaceable Tlingit cultural objects. The city was rebuilt and was incorporated in 1946. The population supports itself through commercial fishing and logging, and many maintain a subsistence lifestyle.

According to historical reports, the 1964 earthquake was widely felt in Hoonah, rattling windows and doors, breaking boat moorings, and causing a tsunami of unrecorded height along with higher-than-normal tides (National Research Council, 1972). Although no damage was reported in Elfin Cove during the 1964 earthquake, two waves were recorded at heights of 6 to $7 \mathrm{ft}$ (1.8 to $2.1 \mathrm{~m}$ ) (National Research Council, 1972). There is no information on the effects of the 1964 tsunami on Gustavus. The $\mathrm{M}_{\mathrm{s}} 7.9$ earthquake of July 10, 1958 , triggered a rock fall in Glacier Bay, which resulted in a wave about $1 \mathrm{~m}(3 \mathrm{ft})$ high at Gustavus.

In all three communities the impact of a tsunami event could potentially be magnified by the remoteness and relative inaccessibility of viable transportation. Along with the potential threat to tourism, there is concern over potential losses to the local fishing industry and infrastructure due to the 
relatively low elevation near coastal location of facilities. Thus, to help mitigate the hazard posed by potential tsunami waves, we have developed tsunami inundation maps for Elfin Cove, Gustavus, and Hoonah in the scope of the National Tsunami Hazard Mitigation Program. These remote southeastern Alaska communities will benefit from tsunami hazard maps that summarize potential tsunami impact on the population and infrastructure.

\section{REGIONAL SEISMOTECTONICS}

The primary tectonic elements of the Pacific/North American plate boundary in southern Alaska are the Alaska-Aleutian megathrust, the Chugach St. Elias (CSE) fold and thrust belt, and the $>1,000-\mathrm{km}$ long (>620-mi-long) Fairweather-Queen Charlotte (FW-QC) fault system (fig. 1). In southeastern Alaska, plate motion is accommodated along the Fairweather fault, a transform fault that extends primarily offshore along the entire southeastern Alaska coastline, becoming the Queen Charlotte fault to the south in British Columbia (fig. 4). Fletcher and Freymueller (2003) estimate a slip rate of $\sim 44.6 \pm 2.0 \mathrm{~mm} / \mathrm{yr}(\sim 1.8 \pm 0.08$ in/yr) for the northern Fairweather fault, one of the highest rates observed across any strike-slip fault in the world. Figure 4 shows rupture areas of large historical earthquakes and seismic activity in southeastern Alaska with locations determined by the Alaska Earthquake Center at the University of Alaska-Fairbanks. Prior to initiation of a regional seismic network in Alaska in the early 1970s, only larger events with $\mathrm{M}_{\mathrm{w}} \geq 6$ could be located. Since the installation of the network, events of smaller size can be detected.

The entire Fairweather-Queen Charlotte fault system has ruptured in large strike-slip earthquakes over the last century: 1927 (Ms7.1), 1949 (Ms8.1,), 1958 (Ms7.9), and 1972 (Ms7.6) (Sykes, 1971; Page, 1973; Tocher, 1960). The 1958 event, known as the "Lituya Bay earthquake," triggered a large landslide into Lituya Bay (fig. 2) that generated a 530-m-high (1,740-ft-high) splash (Miller, 1960). Analysis of these events

Figure 3. a. Docks in Elfin Cove (photo courtesy of Alaska Department of Commerce, Community, and Economic Development, Division of Community and Regional Affairs [DCCED/DCRA]). b. Aerial view of Gustavus, seen from northwest (photo by John Abella). c. View of the Hoonah shoreline (photo courtesy of DCCED/DCRA).

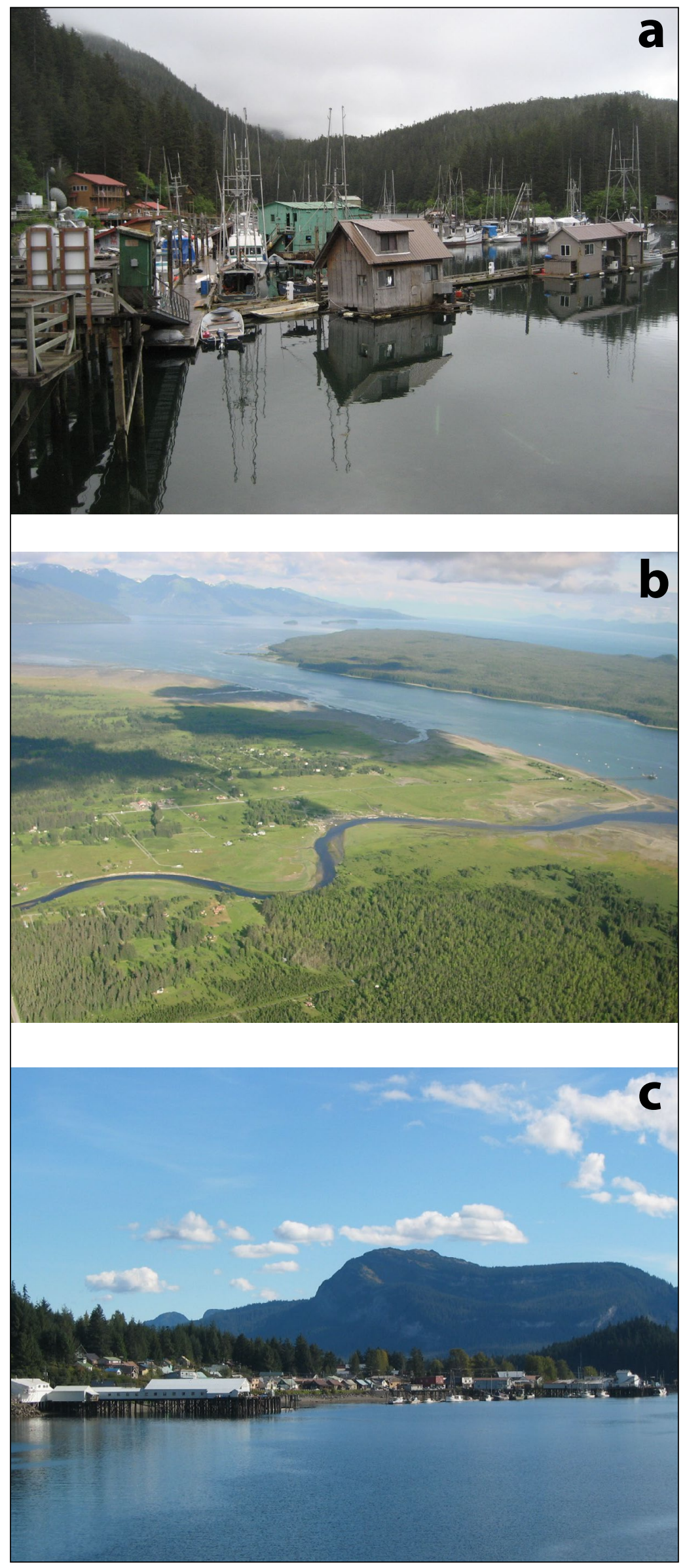




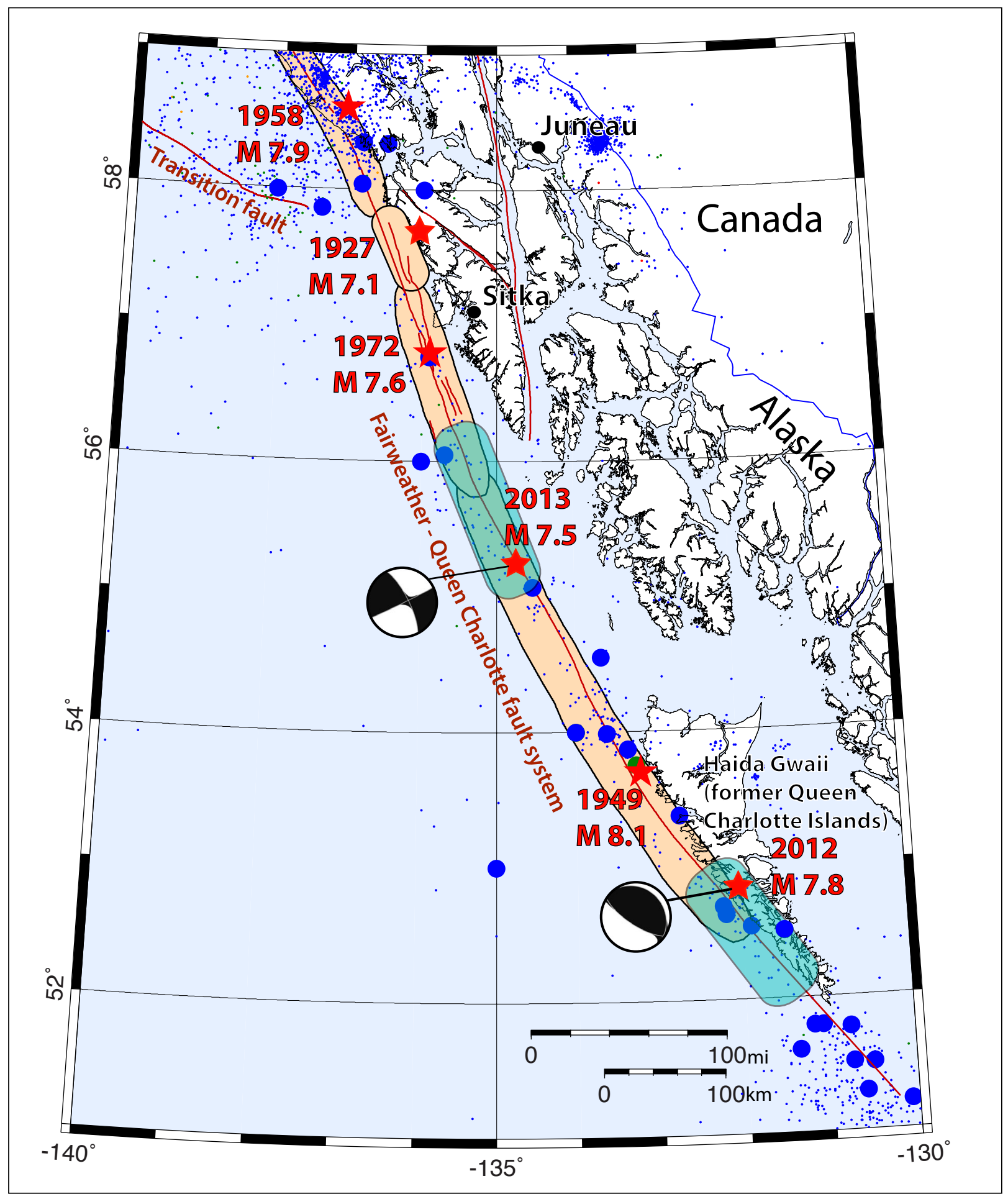

Figure 4. Earthquakes in southeastern Alaska, from the Alaska Earthquake Center catalog. Tiny dots correspond to earthquakes with magnitudes less than 5. Large circles show significant earthquakes of magnitude 5 and greater. Red stars are epicenters of large earthquakes. Shaded peach areas indicate rupture zones of historic earthquakes, and turquoise shaded areas are rupture zones of the two most recent earthquakes along the FW-QC fault system. 
indicate that seismic slip along the FW-QC fault system is parallel to the direction of motion between the North American and the Pacific plates (Doser and Lomas, 2000). Most of the modern seismic events along the Fairweather fault in this area are larger magnitude aftershocks of these historic sequences. Fletcher and Freymueller (2003) estimate that only 75 years is required to build up slip equivalent to the $M_{s} 7.91958$ earthquake along the northern Fairweather fault, and Nishenko and Jacob (1990) have estimated a recurrence interval of 120-130 years for earthquakes similar to the 1972 $M_{\mathrm{S}} 7.6$ Sitka and $1949 \mathrm{M}_{\mathrm{S}} 8.1$ Queen Charlotte earthquakes, respectively.

In the vicinity of Haida Gwaii (formerly known as the Queen Charlotte Islands) relative plate motion is also mainly transform, and accommodated by oblique strike-slip deformation. $\mathrm{A} \mathrm{M}_{\mathrm{S}} 7.5$ earthquake north of Haida Gwaii occurred on January 5, 2013, as a result of shallow strike-slip faulting along the plate boundary, rupturing a $140-\mathrm{km}$-long (87-milong) segment of the fault (AEC event page). The epicenter of this event was $326 \mathrm{~km}$ (203 mi) south of Juneau (fig. 4) and straddles the rupture areas of the 1972 and 1949 events. This event may be related to the October 28, 2012, $\mathrm{M}_{\mathrm{W}} 7.8$ earthquake that occurred to the south of Haida Gwaii along the same plate boundary system. The velocity of the relative plate motion in the area is about $49 \mathrm{~mm}$ (2 in) per year (DeMets and Dixon, 1999). Mazzotti and others (2003) used GPS data to constrain a change in the relative plate motion from mainly transform to oblique strike-slip from north to south along the plate boundary, respectively. Their results indicate that convergence rates change from about $8 \mathrm{~mm}(0.3 \mathrm{in})$ per year to about $15 \mathrm{~mm}(0.6 \mathrm{in})$ per year from northern to southern Haida Gwaii (fig. 4). Plate motion models indicate about 20 degrees of current oblique convergence that started about $5 \mathrm{Ma}$ (DeMets and others, 1990; DeMets and Dixon, 1999). Two models exist to explain the accommodation of convergence off Haida Gwaii: internal shortening (for example, Rohr and others, 2000) versus underthrusting of the Pacific plate (for example, Smith and others, 2003). Mazzotti and others (2003) concluded that the GPS data cannot discriminate between the two models, showing that while 6-7 $\mathrm{mm}(0.23-0.27 \mathrm{in})$ per year of convergence is accommodated by internal shortening, the remaining $6-10 \mathrm{~mm}(0.23-0.39 \mathrm{in})$ per year of convergence cannot be unambiguously assigned to either of the two proposed mechanisms. Recent studies of oblique convergence across the Queen Charlotte fault (Smith and others, 2003; Bustin and others, 2007) compiled different geophysical data and demonstrated strong evidence for an underthrusting model that was also supported by a detailed teleseismic receiver function analysis. The studies concluded that the 10-km-thick (6.2-mi-thick), low-velocity zone dipping to the east at 28 degrees defines the underthrusting oceanic crust located beneath a thin continental crust (Bustin and others, 2007). The mechanism of the recent $M_{W} 7.8$ Haida Gwaii earthquake (fig. 4) was oblique shallow thrusting on a northeastward-dipping fault plane (dip $18.5^{\circ}$, strike $320^{\circ}$ ), and provides additional support for Pacific Plate underthrusting beneath Haida Gwaii (Lay and others, 2013).

\section{METHODOLOGY AND DATA}

\section{GRID DEVELOPMENT AND DATA SOURCES}

One of the problems in tsunami modeling is that the governing equations for water dynamics are continuous. In this report we discretize the shallow-water equations in spherical coordinates on an Arakawa C-grid (Arakawa and Lamb, 1981) using a finite difference method. To resolve a wave the grid must be fine enough, at least four points per wavelength (Titov and Synolakis, 1995); more points than that are often necessary to achieve satisfactory accuracy (for example, Titov and Synolakis, 1997). To compute a detailed map of potential tsunami inundation triggered by local and distant earthquakes, we employ a series of nested computational grids. A nested grid allows for higher resolution in areas where it is needed, without expending computer resources in areas where it is not. The bathymetric and topographic relief in each nested grid is based on digital elevation models (DEMs) developed at the National Geophysical Data Center (NGDC) of the National Oceanic \& Atmospheric Administration (NOAA), in Boulder, Colorado. The extent of each grid used for inundation mapping of Elfin Cove, Gustavus, and Hoonah is listed in table 1. The coarsest grid spans the central and northern Pacific Ocean and has a resolution of 2 arc-minutes $(\sim 2 \mathrm{~km})$, while the highest-resolution grids are localized near the communities (fig. 5). The spatial resolution of the high-resolution grid, $15 \times 16 \mathrm{~m}(49 \times 52$ $\mathrm{ft}$ ), satisfies NOAA minimum recommended requirements for computation of tsunami inundation (National Tsunami Hazard Mitigation Program [NTHMP], 2010).

The bathymetry data for the 2-arc-minute resolution grid shown in figure 5 is extracted from the ETOPO2 data set (National Oceanic and Atmospheric Administration [NOAA], National Geophysical Data Center [NGDC], http://www. ngdc.noaa.gov/mgg/bathymetry/relief.html). To develop $15 \mathrm{~m}, 2.7-$, 8-, and 24-arc-second resolution grids, shoreline, bathymetric, and topographic digital datasets were obtained from several U.S. federal and academic agencies, including: NOAA's National Ocean Service, Office of Coast Survey, and NGDC; the U.S. Fish \& Wildlife Service (FWS); the U.S. Geological Survey (USGS); and the U.S. Army Corps of Engineers (USACE). All data were shifted to World Geodetic System 1984 (WGS 84) horizontal and Mean Higher High Water (MHHW) vertical datums. The data sources and methodology used to create the 24-, 8-, and 2.7-arc-second DEMs are described in greater detail in Caldwell and others (2012) and Lim and others (2011). The high-resolution grids for Elfin Cove, which were used to calculate the extent of inundation and flow depths, are described in Love and others (2011), and the high-resolution DEM development report for Gustavus and Hoonah is presented in Carignan and others (2012). The horizontal datum for these grids is WGS84, and the vertical datum is MHHW. 
Table 1. Nested grids used to compute propagation of tsunami waves to the communities of Elfin Cove, Gustavus, and Hoonah. High-resolution grids are used to compute the inundation. Note that the grid resolution in meters is not uniform and is used to illustrate grid fineness near the communities. The first dimension is the longitudinal grid resolution, while the second is the latitudinal one.

\begin{tabular}{|c|c|c|c|c|}
\hline \multirow{2}{*}{ Grid name } & \multicolumn{2}{|c|}{ Resolution } & \multirow{2}{*}{ West-East boundaries } & \multirow{2}{*}{ North-South boundaries } \\
\hline & Arc-seconds & Meters & & \\
\hline $\begin{array}{l}\text { Northern Pacific, } \\
\text { Level } 0\end{array}$ & $120 " \times 120 "$ & $1,850 \times 3,700$ & $120^{\circ} 00^{\prime} \mathrm{E}-100^{\circ} 00^{\prime} \mathrm{W}$ & $10^{\circ} 00^{\prime} \mathrm{N}-65^{\circ} 00^{\prime} \mathrm{N}$ \\
\hline $\begin{array}{l}\text { Southeastern } \\
\text { Alaska, Level } 1\end{array}$ & $24^{\prime \prime} \times 24 "$ & $402 \times 740$ & $130^{\circ} 00^{\prime} \mathrm{W}-141^{\circ} 00^{\prime} \mathrm{W}$ & $54^{\circ} 00^{\prime} \mathrm{N}-60^{\circ} 00^{\prime} \mathrm{N}$ \\
\hline $\begin{array}{l}\text { Juneau West, } \\
\text { Level } 2\end{array}$ & $8^{\prime \prime} \times 8^{\prime \prime}$ & $132 \times 246$ & $133^{\circ} 15^{\prime} \mathrm{W}-137^{\circ} 15^{\prime} \mathrm{W}$ & $55^{\circ} 45^{\prime} \mathrm{N}-59^{\circ} 36^{\prime} \mathrm{N}$ \\
\hline $\begin{array}{l}\text { Chatham Strait, } \\
\text { Level } 3\end{array}$ & $2.7^{\prime \prime} \times 2.7^{\prime \prime}$ & $44 \times 82$ & $135^{\circ} 20^{\prime} 51^{\prime \prime} \mathrm{W}-136^{\circ} 53^{\prime} 57^{\prime \prime} \mathrm{W}$ & $58^{\circ} 02^{\prime} 22^{\prime \prime} \mathrm{N}-58^{\circ} 33^{\prime} 05^{\prime \prime} \mathrm{N}$ \\
\hline $\begin{array}{l}\text { Elfin Cove, high- } \\
\text { resolution grid }\end{array}$ & $0.9^{\prime \prime} \times 0.53^{\prime \prime}$ & $14.5 \times 16.5$ & $136^{\circ} 18^{\prime} 50^{\prime \prime} \mathrm{W}-136^{\circ} 25^{\prime} 25^{\prime \prime} \mathrm{W}$ & $58^{\circ} 09^{\prime} 07^{\prime \prime} \mathrm{N}-58^{\circ} 13^{\prime} 37^{\prime \prime} \mathrm{N}$ \\
\hline $\begin{array}{l}\text { Gustavus, high- } \\
\text { resolution grid }\end{array}$ & $0.9^{\prime \prime} \times 0.53^{\prime \prime}$ & $14.5 \times 16.5$ & $135^{\circ} 33^{\prime} 02^{\prime \prime} \mathrm{W}-135^{\circ} 57^{\prime} 35^{\prime \prime} \mathrm{W}$ & $58^{\circ} 20^{\prime} 37^{\prime \prime} \mathrm{N}-58^{\circ} 28^{\prime} 32^{\prime \prime} \mathrm{N}$ \\
\hline $\begin{array}{l}\text { Hoonah, high- } \\
\text { resolution grid }\end{array}$ & $0.9^{\prime \prime} \times 0.53^{\prime \prime}$ & $14.5 \times 16.5$ & $135^{\circ} 23^{\prime} 31^{\prime \prime} \mathrm{W}-135^{\circ} 30^{\prime} 17^{\prime \prime} \mathrm{W}$ & $58^{\circ} 04^{\prime} 58^{\prime \prime} \mathrm{N}-58^{\circ} 09^{\prime} 20^{\prime \prime} \mathrm{N}$ \\
\hline
\end{tabular}

\section{NUMERICAL MODEL OF TSUNAMI WAVE PROPAGATION AND RUNUP}

A technical memorandum published by NOAA outlines the major requirements for numerical models used in inundation mapping and tsunami forecasting, and describes a procedure for model evaluation (National Tsunami Hazard Mitigation Program, 2010). There are two major components to this process. The first is model validation, which ensures that the model correctly solves appropriate equations of motion by comparing model results with known solutions. This is achieved through analytical and laboratory benchmarking. The second component is model verification (testing the model) using observations of real events through field data benchmarking. The numerical model currently used by the Alaska Earthquake Center for tsunami inundation mapping has been validated through a set of analytical benchmarks and tested against laboratory and field data (Nicolsky and others, 2011; Nicolsky, 2012). The model solves nonlinear shallow-water equations using a finite-difference method on a staggered grid. For any coarse-fine pair of computational grids, we apply a time-explicit numerical scheme as follows. First, we compute the water flux in a coarse-resolution grid. These computed flux values are used to define the water flux on a boundary of the fine-resolution grid. Next the water level and then the water flux are calculated over the fine-resolution grid. Finally, the water level computed in the fine-resolution grid is used to define the water level within the area of the coarse-resolution grid that coincides with the fine grid. Despite the fact that developed nested grids decrease the total number of grid cells needed to preserve computational accuracy in certain regions of interest, actual simulations are still prohibitive if parallel computing is not implemented. Here, we use the Portable Extensible Toolkit for Scientific computation (PETSc), which provides sets of tools for the parallel numerical solution of shallow-water equations. In particular, each computational grid listed in table 1 can be subdivided among an arbitrary number of processors. The above-mentioned passing of information between the water flux and level is implemented efficiently using PETSc subroutines.

We assess tsunami hazard in Icy Strait by performing model simulations for each tsunami source scenario. To simulate tsunami dynamics caused by a seafloor deformation from an earthquake, we assume some simplifications. First, an initial displacement of the ocean surface is equal to the vertical displacement of the ocean floor induced by the earthquake rupture process. Second, we do not account for the finite speed of the rupture propagation along the fault and consider the ocean bottom displacement to be instantaneous.

At the end of a tsunami simulation, each of the grid points has a value of either 0 if no inundation occurs, or 1 if seawater reaches the grid point at any time. The inundation line approximately follows the 0.5 contour between these 0 and 1-point values but was adjusted visually to accommodate obstacles or local variations in topography not represented by the DEM. Although the developed algorithm has passed through rigorous benchmarking procedures (Nicolsky and others, 2011; Nicolsky, 2012), some uncertainty in the exact location of the inundation line is unavoidable. Complexities in the modeling process make this uncertainty difficult to quantify. Many factors can affect the estimated location of the inundation line, including suitability of the earthquake source model, accuracy of the bathymetric and topographic data, and adequacy of the numerical model in representing the generation, propagation, and run-up of tsunami waves. In this report we do not attempt to adjust the modeled inundation limits to account for these uncertainty factors. 


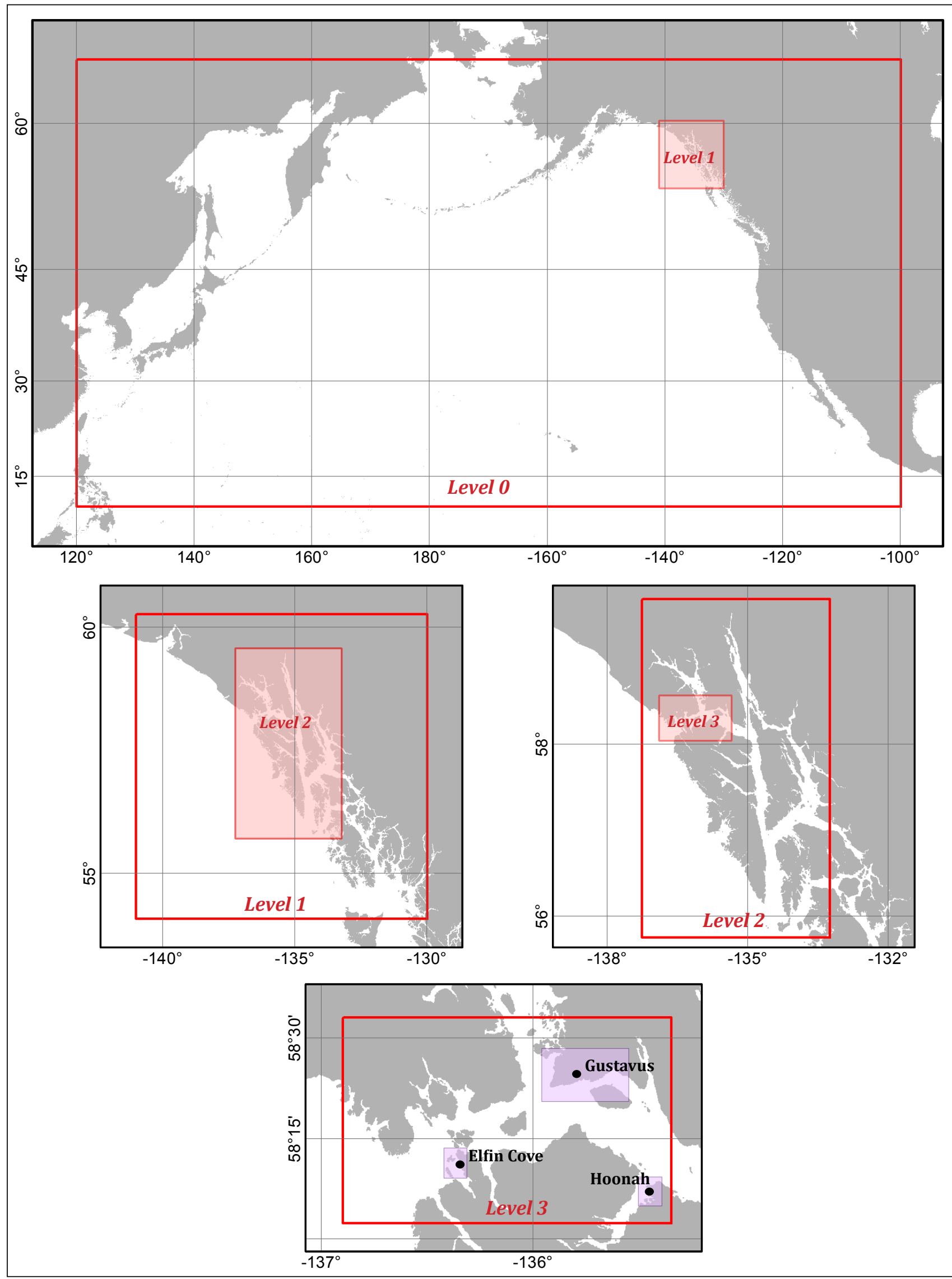

Figure 5. Telescoping embedded bathymetry/topography grids for numerical modeling of tsunami propagation and runup. The lowest resolution grid, Level 0 , covers the central and northern Pacific Ocean. Location of each embedded grid is marked by a pink rectangle. Locations of the highest resolution grids for runup calculation are marked by purple rectangles in the lower figure. Refer to table 1 for grid parameters. 
One of the limitations of the model is that it does not take into account the periodic change of sea level caused by tides. We conducted all model runs using bathymetric data that correspond to MHHW. As a result, the elevation of the inundation line could differ slightly from what is provided in this report, depending on the tides at the time of a tsunami.

\section{NUMERICAL MODEL OF LANDSLIDE- GENERATED TSUNAMIS}

To simulate tsunamis produced by hypothetical underwater slope failures in Taylor Bay and Port Frederick, we use a numerical model with two components: a viscous underwater slide model and a water wave model. The developed model assumes full coupling between the deforming slide and the water waves that it generates. A coupling of these two components was previously accomplished by Jiang and LeBlond $(1992,1994)$ and later improved by Fine and others (1998) by including realistic bathymetry, and by correcting errors in the governing equations. The model's assumptions and applicability to simulating underwater mudflows are discussed by Jiang and LeBlond (1992, 1994). The model uses longwave approximation for water waves and the deforming slide, which means that the wavelength is much greater than the local water depth and the slide thickness is much smaller than the characteristic length of the slide along the slope (Jiang and LeBlond, 1994). Assier-Rzadkiewicz and others (1997) argued that the long-wave approximation could be inaccurate for slopes exceeding 10 degrees. Rabinovich and others (2003) studied the validity of the long-wave approximation for slopes greater than 10 degrees and found that for a slope of 16 degrees, the possible error was 8 percent, and for the maximum slope in their study ( 23 degrees), the possible error was 15 percent. The average offshore slope of the glacial moraine in Taylor Bay is about 3 degrees, and the offshore slope in the area of a hypothetical slide in Port Frederick is about 8 degrees, from which we infer that the long-wave approximation is applicable to the proposed slide scenarios.

The advantage of the vertically integrated model by Jiang and LeBlond (1992) is its ability to simulate runup of real landslide tsunami events using high-resolution numerical grids. Although model runs require the use of high-performance computing, the computational times are still reasonable. This model was successfully applied to simulate a tsunami event in Skagway Harbor, one of numerous fjords in southeastern Alaska, where tsunamis were generated by a submarine landslide on November 3, 1994 (Fine and others, 1998; Thomson and others, 2001). The results of numerical simulations were in good agreement with the tide gauge record in Skagway Harbor. Rabinovich and others (2003) simulated potential underwater landslides in British Columbia fjords, with settings similar to bays and fjords of southeastern Alaska, and demonstrated that this model can also be used for tsunami hazard assessment.

Modeling of waves generated by a rapid failure of bedrock from the fjord walls presents a major difficulty in tsunami hazard assessment. The impact of a rockfall on the water surface results in a turbulent splash and consequent mixing of the rockfall and granular flow with water. As the rockfall material submerges, a non-linear interaction between the rockfall material and the water occurs that further influences the evolution of the tsunami. Typically, there are several regions with distinct tsunami features considered around a rockfall. In the splash zone, turbulent and chaotic water behavior (Fritz, 2002) can be modeled up to a certain extent by the 3-D Navier-Stokes equations coupled with an appropriate model of the slide (Heinrich, 1992; Heinrich and others, 1998). The choice of slide model depends on the type of material involved and its general rheology. Beyond the splash zone, in the so-called near-field zone, chaotic waves evolve into a well-defined wave that propagates away from the slide. Finally, the far-field zone is characterized by a steady partitioning of the kinematic and potential energy and by a well-defined waveform. Identifying these zones is a complicated task and involves both theoretical and experimental studies (Mei, 1983; Fritz, 2002; Walder and others, 2006). On the other hand, if the splash zone is much smaller than the distance to a location where the runup needs to be assessed, then it is common to assume that the splash zone is a "black box" (Walder and others, 2006). The water wave is thought to be emerging from the black box with well-defined characteristics, that is, the wave exiting the splash zone is approximated by a soliton (Watts and Waythomas, 2003; Waythomas and others, 2006) or a parabola (Wieczorek and others, 2007). The initial wave height is parameterized by its slide volume, density, thickness, and velocity when the slide plunges into the water. To simulate tsunami waves generated by a potential rock fall in Tidal Inlet, we apply the impact tsunami theory described by Ward and Asphaug (2002). Their model was developed for asteroid-generated tsunamis to define the initial wave height for calculation of wave propagation. Geist and others (2003) as well as Wieczorek and others (2007) give a detailed description of the landslide impact model and its application to estimate the waves from a potential Tidal Inlet rock fall. We emphasize that, along with the numerical modeling assumptions in the splash zone, the geometry and configuration of the rockfall introduces most of the uncertainties in the presented modeling.

To model the initial displacement of the water surface from a rockfall in Tidal Inlet, we developed a local grid that covers the inlet and has a resolution of $30 \times 40 \mathrm{~m}(98 \times 131$ $\mathrm{ft}$ ). This grid was dynamically connected in the model to the 8 - and 2.7 -arc-second grids, and then to the $15 \mathrm{~m}$ grid of Gustavus to calculate the effects of the generated waves on the community.

\section{HISTORICAL TSUNAMIS IN ICY STRAIT}

In the following section we describe the results of numerical modeling of historical tsunamis that affected Elfin Cove: (a) Tohoku 2011, and (b) Haida Gwaii 2012. We modeled these events for the purpose of site-specific model verification and to evaluate their modeled coseismic deformation for use in the development of hypothetical tsunami sources. The Tohoku 2011 and Haida Gwaii 2012 events represent farand near-field tsunami sources, respectively, with different directional properties. 


\section{The Tohoku tsunami of March 11, 2011}

The catastrophic Tohoku tsunami of March 11, 2011, produced a small wave in Elfin Cove, with a maximumrecorded wave amplitude of $21 \mathrm{~cm}(8.3 \mathrm{in})$. The tsunami source functions that represent the slip distribution of the 2011 Tohoku earthquake were provided by Guangfu Shao of the University of California Santa Barbara (UCSB) (Shao and others, 2011); Shengji Wei of Caltech Tectonic Observatory (http://www.tectonics.caltech.edu/); and the NOAA Center for Tsunami Research (Tang and others, 2012). We calculated vertical coseismic deformation resulting from the given slip models using the equations of Okada (1985). The resulting tsunami source functions are shown in figure 6. Figure 7 shows a comparison between the observed wave history at Elfin Cove as recorded by the Elfin Cove tidal station, and the calculated time series at the same location. The time series point was located in the Elfin Cove numerical grid of $15 \mathrm{~m}$ resolution. The simulated time series demonstrate that the models of Shengji Wei and Guangfu Shao provide the best fit to the arrival of the first wave. All three models provide a good fit to the wave phases of oscillations recorded by the tidal station for the first 2 hours. The plot illustrates that the far-field Tohoku tsunami did not produce a significant wave at Elfin Cove due to directivity of the tsunami source (waves directed primarily to the northwest and southeast) and the resulting energy propagation patterns (Tang and others, 2012).

\section{The Haida Gwaii tsunami of October 28, 2012}

The Haida Gwaii earthquake of October 28, 2012, generated a tsunami that was recorded at the Elfin Cove tide gauge as well as at a number of tide stations along the west coast of the U.S. The tsunami produced significant local runup $(>7 \mathrm{~m}$ in places) along the west coast of Haida Gwaii (James and others, 2013). We obtained four source models of this event that were based on seismic waveform inversion of the slip distribution: the Caltech source (http://www.tectonics.caltech. edu/); the USGS source (http://earthquake.usgs.gov/); the source function by Chen Ji (http://www.geol.ucsb.edu/ faculty/ji/big_earthquakes/2012/10/canada.html); and the slip distribution by Lay and others (2013). These four source functions are shown on figure 8 . We simulated the tsunami wave history at the point that corresponds to the location of the Elfin Cove tidal station using our validated tsunami model (Nicolsky and others, 2011; Nicolsky, 2012). Figure 9 demonstrates a comparison between the recorded wave and the simulated time history corresponding to the four source functions. The time series point was located in the Elfin Cove numerical grid of $15 \mathrm{~m}$ resolution. The simulated time series demonstrate that the model of Lay and others (2013) provides the best fit to the amplitudes of the recorded wave for up to 2.5 hours after the arrival of the first wave. All four models provide a good fit to the wave phases of oscillations recorded by the tidal station (point 5 in fig. A1) for the first 2 hours. We use the source mechanism of the Haida Gwaii earthquake as a basis for the hypothetical near-field tsunami source in the area of Haida Gwaii (scenario 9).

Numerical modeling of two historical tsunamis at Elfin Cove demonstrates that the above-described numerical model of tsunami propagation and runup generates tsunami wave- forms that match up well with the observed arrival times and wave phases. The model also provides a good fit to the recorded tsunami amplitudes, which indicates that the proposed coseismic deformation models for the historical earthquakes adequately describe the coseismic slip distribution.

\section{HYPOTHETICAL TECTONIC TSUNAMI SOURCES}

We consider several tectonic tsunami sources for construction of tsunami hazard maps for the communities in Icy Strait. Taking into account the directional properties of a tsunami source and previous studies of the far-field effects of the 1964 tsunami (Myers and Baptista, 2001; Suleimani, 2011), we conclude that the section of the Alaska-Aleutian megathrust that includes the Alaska Peninsula, Kodiak Island, and Prince William Sound (fig. 10) is the area best positioned to generate a tsunami wave that will significantly affect this region.

To construct regional tsunami scenarios, we analyzed historical events along the Fairweather-Queen Charlotte fault system (figs. 2 and 4). Another hypothetical tsunamigenic earthquake worth considering is rupture of the Cascadia subduction zone, involving subduction of the Juan de Fuca plate beneath the North American plate along the Pacific Northwest coast (from Vancouver Island, British Columbia, to northern California).

In modeling the selected tsunami sources we assume that the initial displacement of the ocean surface is equal to the vertical displacement of the ocean floor induced by the earthquake rupture process. We do not account for the finite speed of rupture propagation along the fault and consider the ocean bottom displacement to be instantaneous.

For the purpose of constructing tsunami source scenarios that span from south-central Alaska to the eastern Aleutians, we follow the notations of Nishenko and Jacob (1990) for the segments of the megathrust that have been repeatedly ruptured by large and great earthquakes, or for gaps between the rupture segments: Yakataga-Yakutat (YY), Prince William Sound (PWS), Kenai Peninsula (KP), Kodiak Island (KI), Semidi Islands (SEM), Shumagin Islands (SH), Unimak Island (UN), and Fox Island (FOX) segments (fig. 10).

We describe below all tsunami sources that were used to calculate propagation and runup of tsunami waves and then included the calculation of the composite extent of inundation and the composite distribution of flow depths. The coseismic deformation pattern for each scenario is shown in figure 11, and table 2 provides a summary of all scenarios.

\section{Source models of hypothetical tsunamigenic earthquakes in the Gulf of Alaska}

Scenario 1. Multi-segment event: The PWS and KP segments of the 1964 rupture, and the YY segment

This model includes coseismic deformation of the PWS and KP segments of the 1964 rupture, and deformation of the YY segment. Vertical displacements in the 1964 rupture zone are based on the coseismic deformation model by Suleimani (2011). A detailed description of this scenario is also provided in Suleimani and others (2013). 

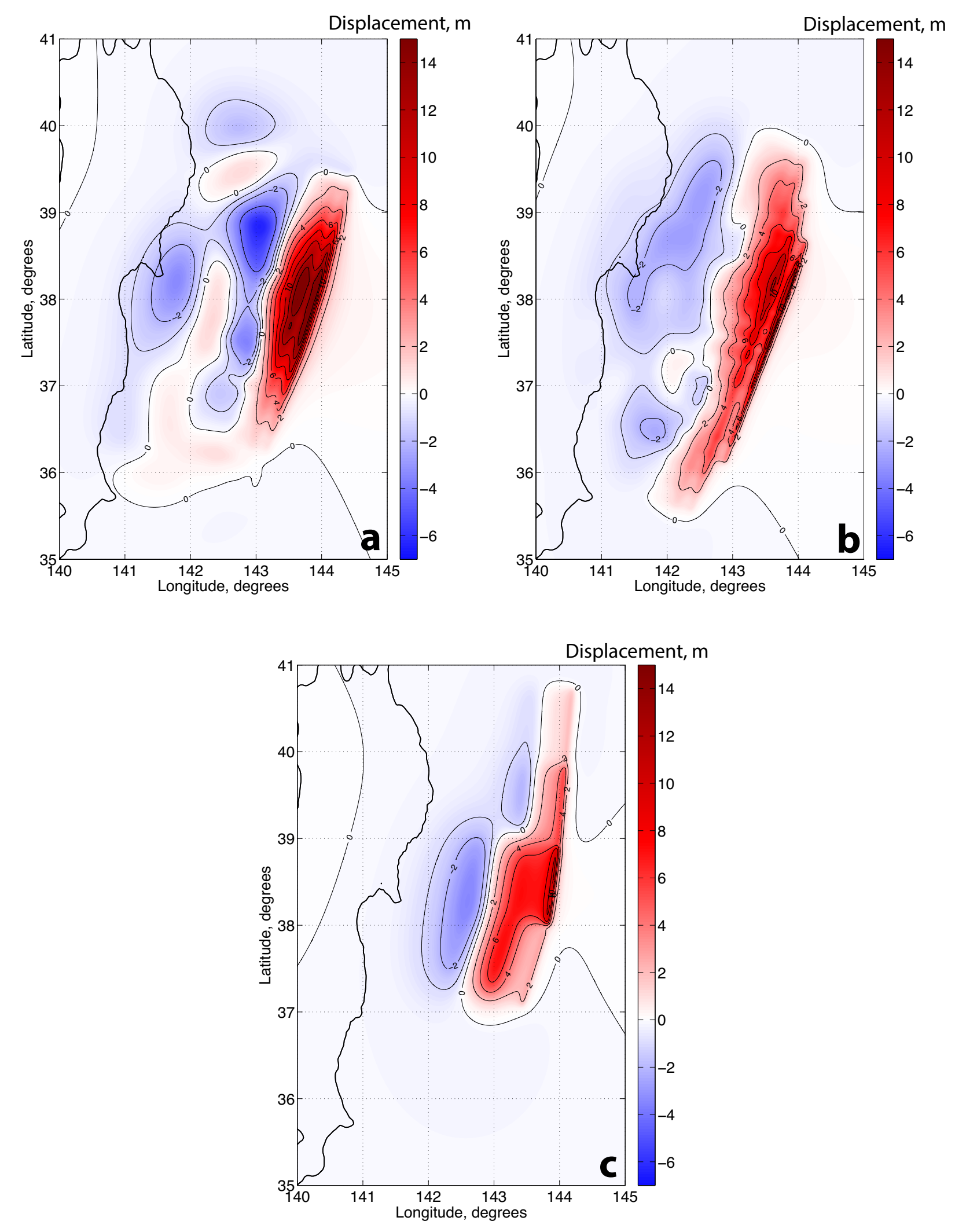

Figure 6. Vertical coseismic deformations for the source models of the 2011 Tohoku tsunami. a. Model by Guangfu Shao of UCSB (Shao and others, 2011). b. Model by Shengji Wei of Caltech Tectonic Observatory (http://www.tectonics.caltech. edu/). c. Model by NOAA Center for Tsunami Research at PMEL (Pacific Marine Environmental Laboratory), described in Tang and others (2012). 


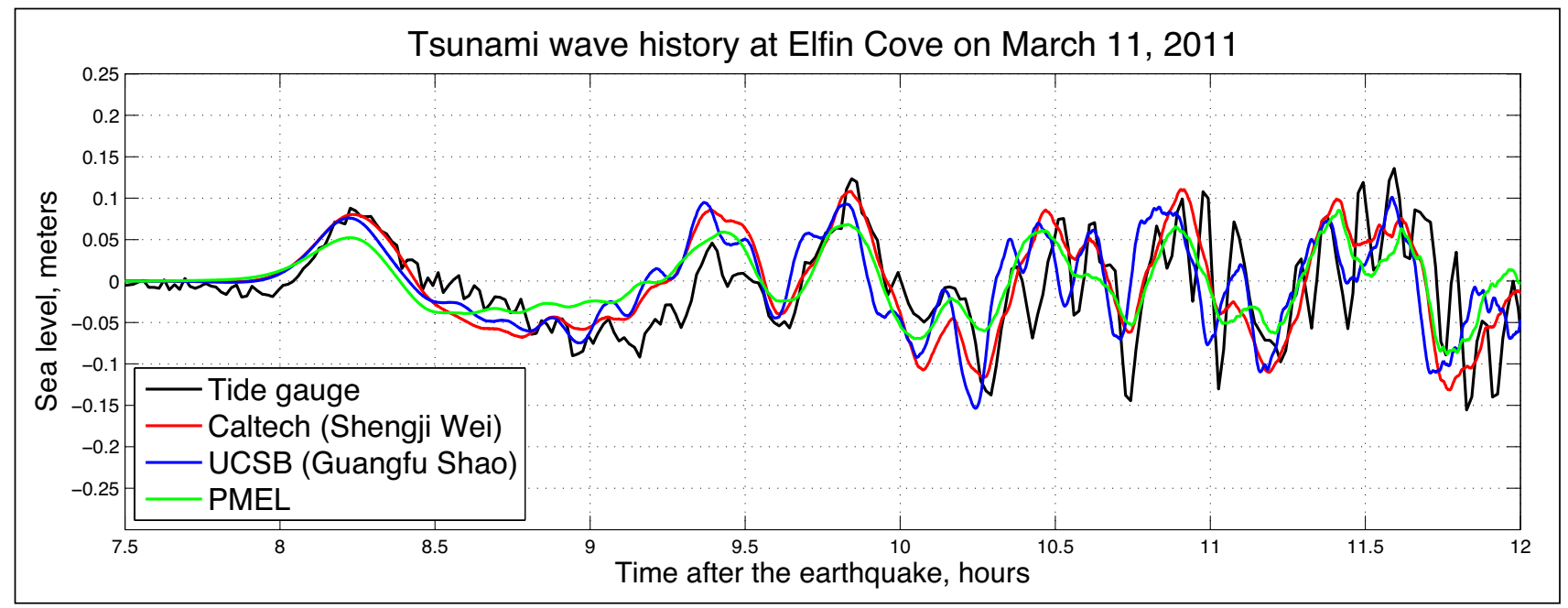

Figure 7. The recorded sea level at Elfin Cove during the 2011 Tohoku tsunami, compared with the time series calculated for the source functions shown in figure 6.

Table 2. Hypothetical tectonic scenarios used to model tsunami runup in Elfin Cove, Gustavus and Hoonah.

\begin{tabular}{|c|c|c|c|c|c|}
\hline \# & $\mathbf{M}_{\mathbf{w}}$ & Description & $\begin{array}{l}\text { Maximum } \\
\text { slip, } \\
\text { m (ft) }\end{array}$ & $\begin{array}{l}\text { Maximum } \\
\text { subsidence, } \\
\mathrm{m}(\mathrm{ft})\end{array}$ & $\begin{array}{l}\text { Maximum } \\
\text { uplift, } \\
\text { m (ft) }\end{array}$ \\
\hline 1 & 9.2 & $\begin{array}{l}\text { Multi-segment event: Rupture of the KP, PWS, } \\
\text { and YY segments }\end{array}$ & $22.5(73.8)$ & $4(13.1)$ & $9.2(30.2)$ \\
\hline 2 & 9.2 & $\begin{array}{l}\text { Multi-segment event: Rupture of the } \mathrm{KI}, \mathrm{KP} \text {, and } \\
\text { PWS segments }\end{array}$ & $36.5(119.6)$ & $4(13.1)$ & $14.5(47.6)$ \\
\hline 3 & 9.0 & $\begin{array}{l}\text { Event in the Gulf of Alaska region, variable slip } \\
\text { along strike (PWS and KP segments) }\end{array}$ & $44.4(145.7)$ & $8(26.2)$ & $13.5(44.3)$ \\
\hline 4 & 9.0 & $\begin{array}{l}\text { Event in the Gulf of Alaska region, uniform slip } \\
\text { along strike (PWS and KP segments) }\end{array}$ & $58.1(190.6)$ & $7.2(23.6)$ & $11.1(36.4)$ \\
\hline 5 & 9.0 & SAFRR Tsunami Scenario (SEM and SH segments) & $75(246)$ & $2.8(9.2)$ & $14.8(48.6)$ \\
\hline 6 & 9.1 & $\begin{array}{l}\text { Rupture in the Eastern Aleutians, from Semidi } \\
\text { Islands to Fox Islands (SEM, SH, UN, and FOX } \\
\text { segments) }\end{array}$ & $36(118)$ & $3(9.8)$ & 14.6 (47.9) \\
\hline 7 & 9.1 & Rupture in the Cascadia subduction zone & 36 (118) & $7.5(24.6)$ & $10.9(35.8)$ \\
\hline
\end{tabular}

Scenario 2. Multi-segment event: The PWS, KP, and KI segments with Tohoku-type slip distribution in the down dip direction

We used a recently published model of global subduction zone geometries, called Slab 1.0 (Hayes and others, 2012), to construct hypothetical tsunami sources along the eastern end of the Alaska-Aleutian megathrust (fig. 10). Suleimani and others (2013) give a detailed description of a sensitivity study aimed at determining which combination of megathrust segments between PWS and SH would produce the highest tsunami amplitudes and runup values in southeastern Alaska. In all hypothetical tsunami sources included in the sensitivity study the slip was distributed almost uniformly along strike, except for the edges of the ruptures, where slip tapers. As for the down dip direction, we assumed the concentration of higher slip closer to the shallow part of the rupture, similar to that in the Tohoku 2011 earthquake (Ito and others, 2011). All sources had the same seismic moment that corresponds to a $\mathrm{M}_{\mathrm{W}} 9.2$ rupture. We conducted a numerical experiment to select the hypothetical source that produces the highest tsunami amplitudes and runup values at Elfin Cove. The superposition of PWS, KP, and KI segments generated the largest tsunami and was chosen as scenario 2 .

\section{Source models of hypothetical Tohoku-type events in the Gulf of Alaska}

In light of the recent $\mathrm{M}_{\mathrm{W}} 9.0$ earthquake off the Pacific coast of Tohoku in 2011, we consider a similar-type event in the Gulf of Alaska region (David Scholl, U.S. Geological Survey, oral commun., 2013; Jeffrey Freymueller, University of Alaska Fairbanks, oral commun., 2013). During the Tohoku event a large amount of slip between the subducting 

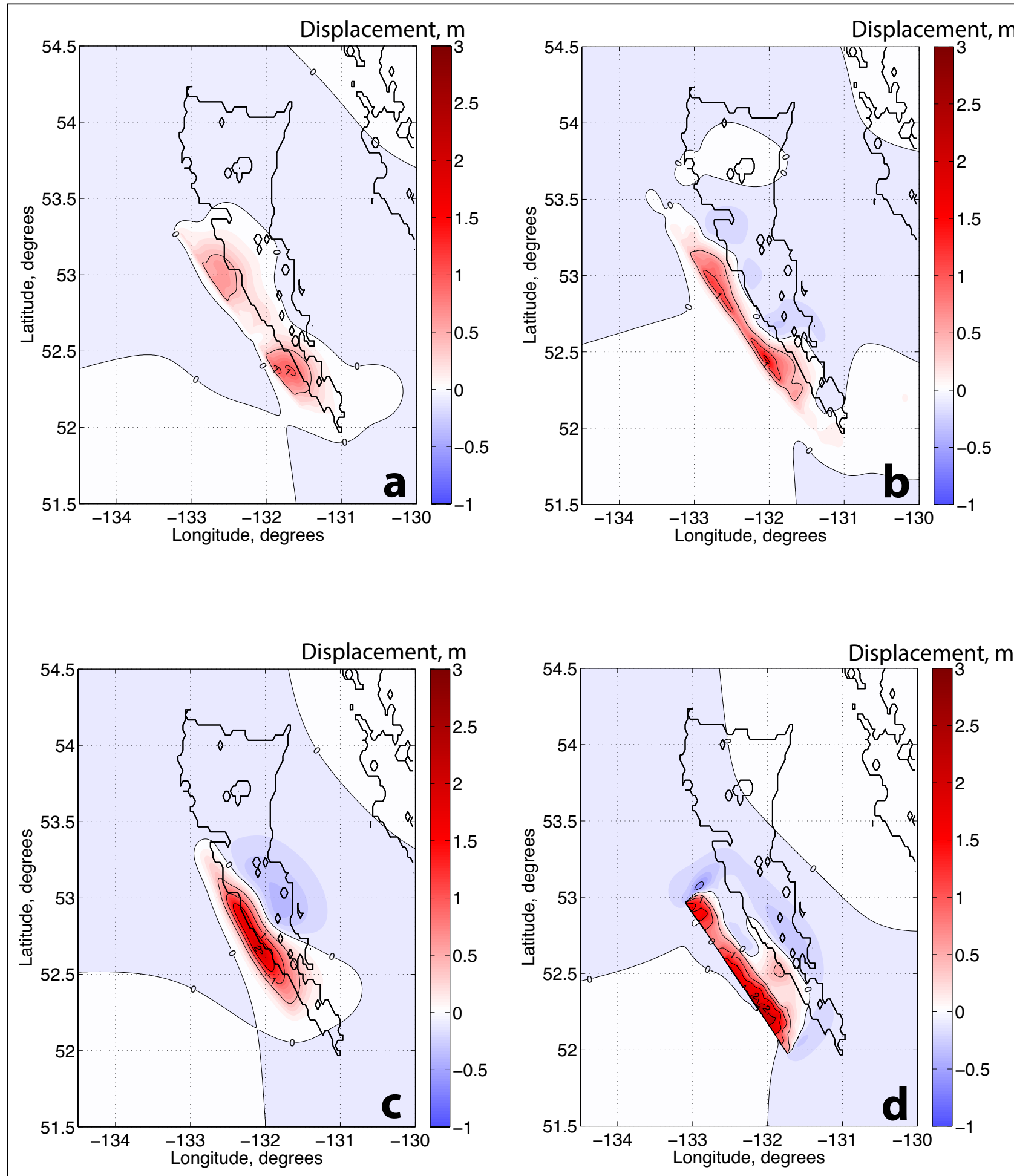

Figure 8. Vertical coseismic deformations corresponding to the four different slip models of the October 28, 2012, Haida Gwaii earthquake. a. Caltech source model (http://www.tectonics.caltech.edu/). b. USGS source model (http://earthquake. usgs.gov/). c. Source model by Chen Ji (http://www.geol.ucsb.edu/faculty/ji/big_earthquakes/2012/10/canada.html). d. Source model by Lay and others (2013). 


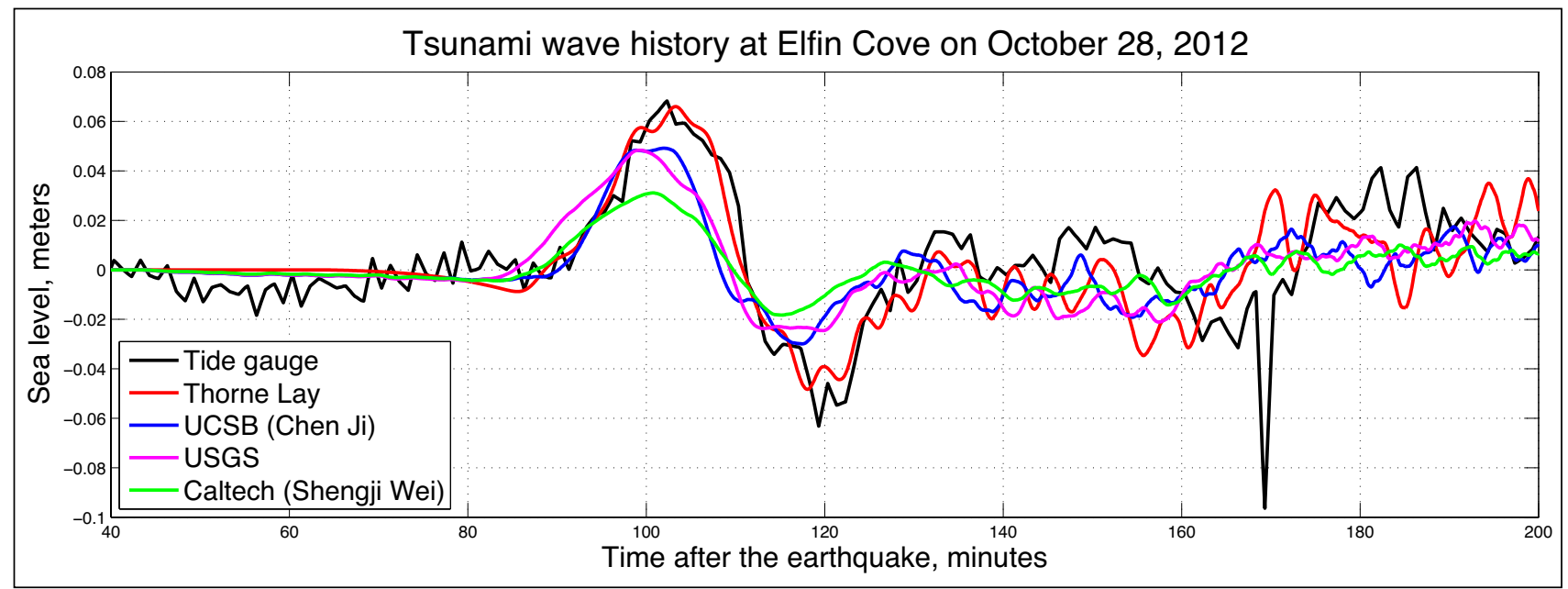

Figure 9. The recorded sea level at Elfin Cove during the 2012 Haida Gwaii tsunami, compared with the time series calculated for four source functions shown in figure 8.

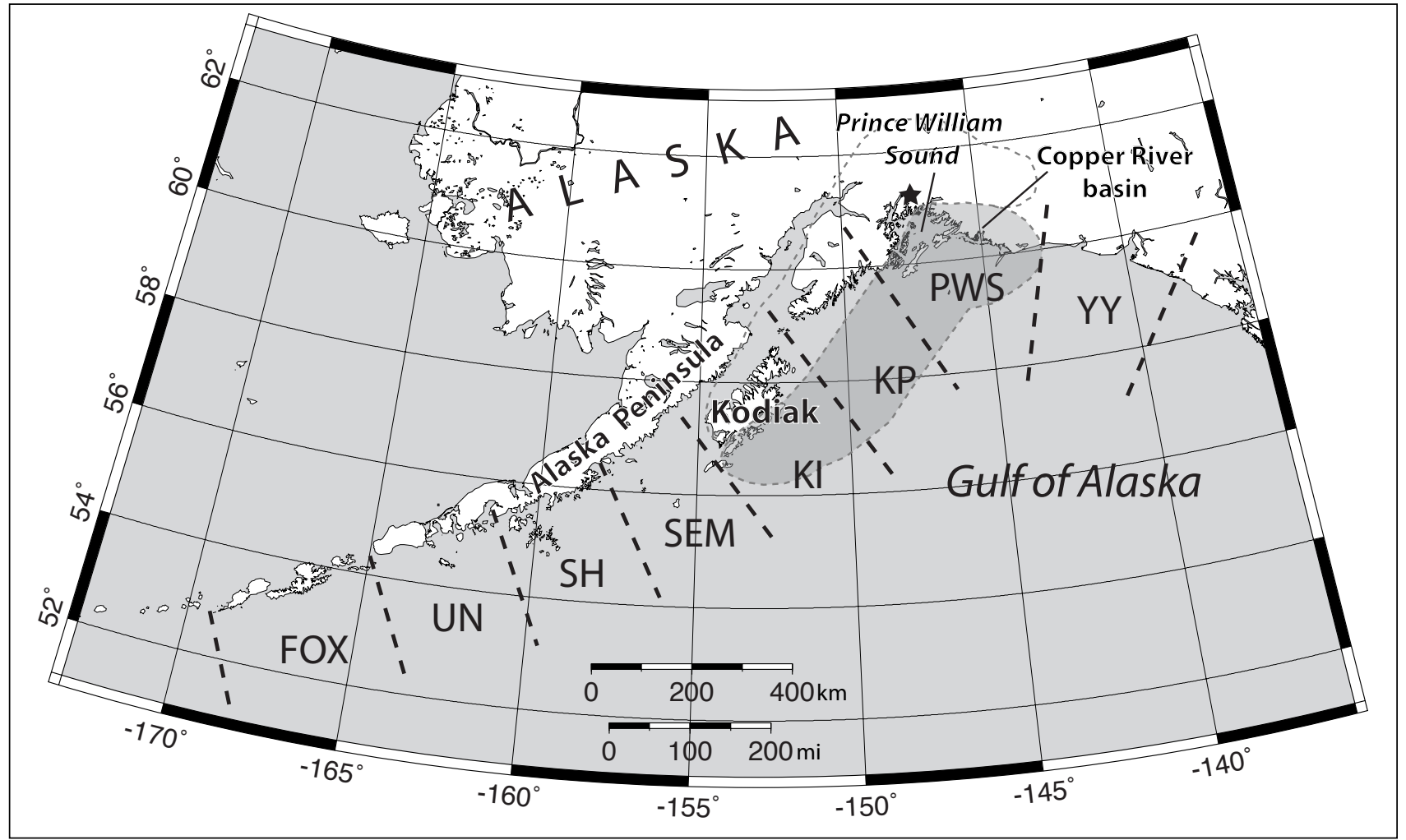

Figure 10. Map of Alaska with rupture zone of the 1964 Great Alaska Earthquake and segments of the Alaska-Aleutian megathrust: Yakataga-Yakutat (YY), Prince William Sound (PWS), Kenai Peninsula (KP), Kodiak Island (KI), Semidi Islands (SEM), Shumagin Islands (SH), Unimak Island (UN), and Fox Islands (FOX). Star indicates the epicenter of the 1964 earthquake; dashed contour delineates regions of coseismic uplift (shaded) and subsidence of the 1964 rupture area (Plafker, 1969). 

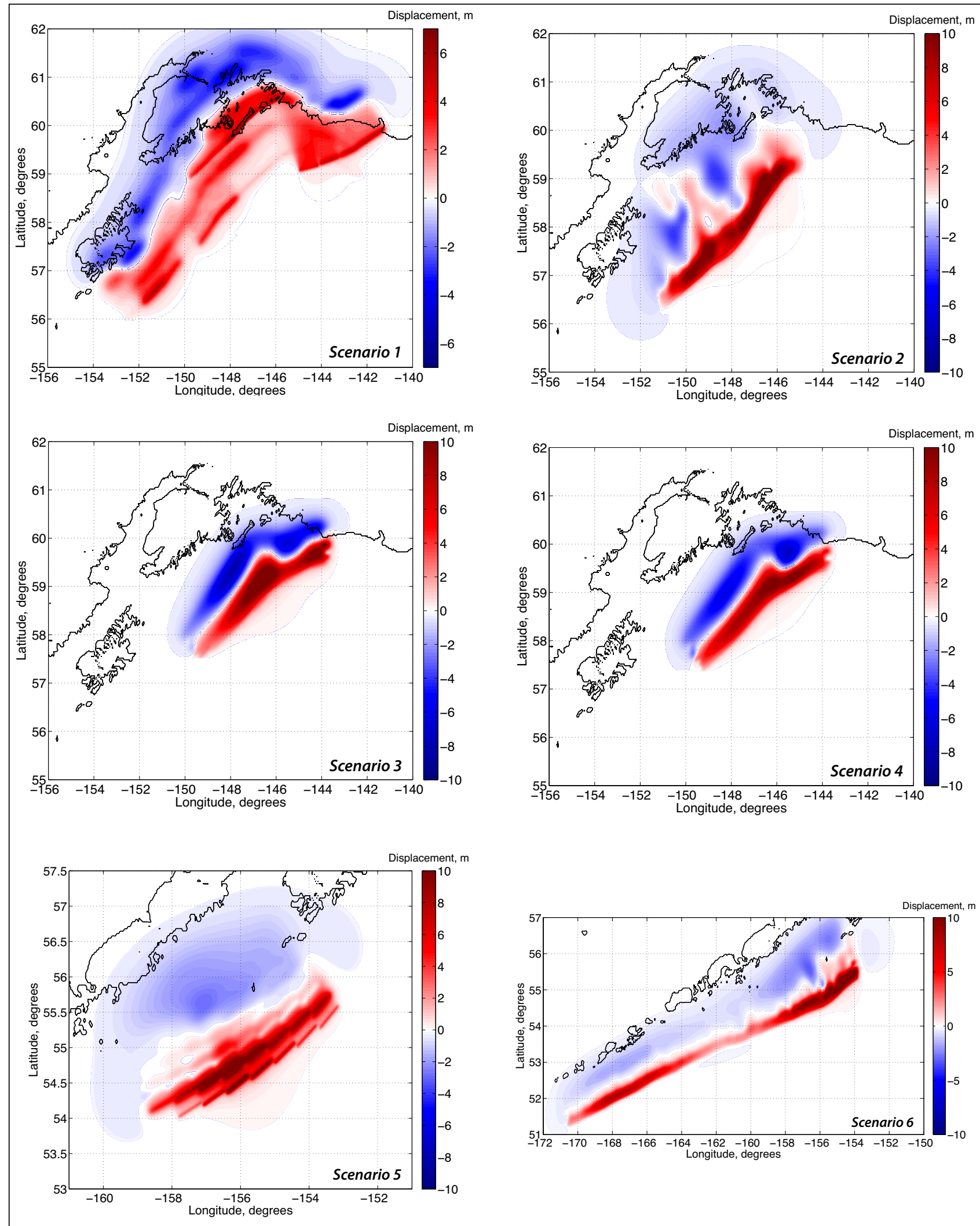

Figure 11. Vertical coseismic deformations corresponding to scenarios 1-7 (scenario 7 on following page). See table 2 for details. 


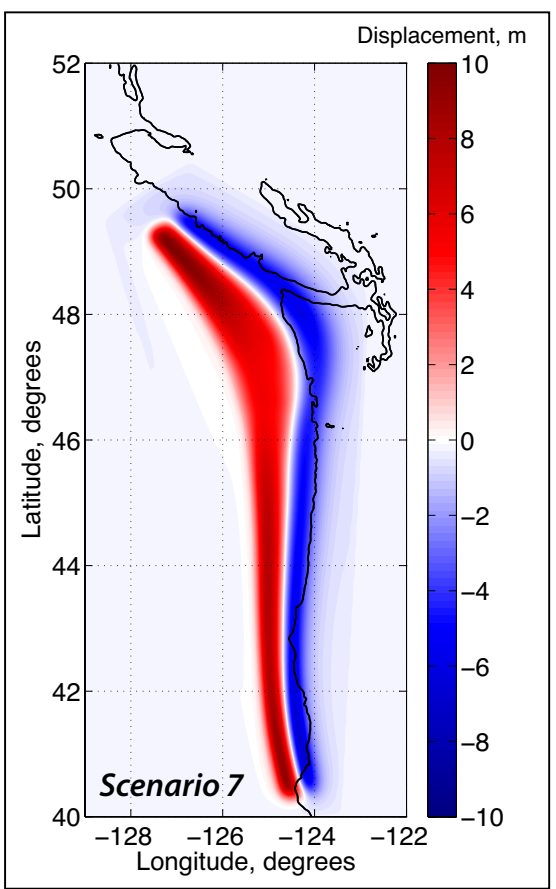

Figure 11 (continued). Vertical coseismic deformations corresponding to scenarios 1-7 (see table 2).

and overriding plates occurred near the Japan trench (Fujii and others, 2011; Shao and others, 2011). In this report we model two hypothetical Tohoku-type events in the Gulf of Alaska region with different distribution of slip along strike. Detailed descriptions of these scenarios can be found in Nicolsky and others (2014).

Scenario 3. $M_{w} 9.0$ event in the Gulf of Alaska region, variable slip along strike

This event is a hypothetical Tohoku-type event rupturing the Prince William Sound asperity of the 1964 earthquake. The slip is distributed in the along-strike direction according to the slip deficit model (Suito and Freymueller, 2009) and is localized between 4 and $18 \mathrm{~km}$ (2.5-11.2 mi) depth according to the parameterization by Freund and Barnett (1976).

Scenario 4. $M_{w} 9.0$ event in the Gulf of Alaska region, uniform slip along strike

This event is also a hypothetical Tohoku-type event rupturing the Prince William Sound asperity of the 1964 earthquake. The slip is uniformly distributed in the alongstrike direction and is localized between 4 and $18 \mathrm{~km}$ (2.5-11.2 mi) depth according to the parameterization by Freund and Barnett (1976).

\section{Source models of hypothetical tsunamigenic earthquakes in the Alaska Peninsula segment of the Alaska-Aleutian subduction zone.}

Scenario 5. SAFRR tsunami scenario: Segments SH and SEM

The USGS Science Application for Risk Reduction (SAFRR) project, in collaboration with NOAA and State of California agencies, has developed a plausible hypothetical tsunami scenario to describe the impacts of a tsunami generated by an earthquake in the Alaska Peninsula region (Ross and others, 2012). The USGS Tsunami Source Working Group defined the scenario source as a M9.0 earthquake similar to the Tohoku 2011 event, but located between the Shumagin Islands and Kodiak Island, in the SH and SEM segments of the megathrust (fig. 10). The rupture area, represented by 56 subfaults, is about $350 \times 200 \mathrm{~km}(217 \times 124 \mathrm{mi})$,

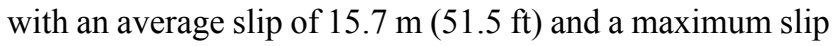
of $75 \mathrm{~m}(246 \mathrm{ft})$. The concentration of higher slip closer to the trench was adopted for the SAFRR scenario following the derived slip distributions for the Tohoku earthquake.

Scenario 6. Multi-segment event: SEM, SH, UN, and FOX segments

This scenario is based on the slip model of a hypothetical earthquake that incorporates the entire rupture areas of the 1788, 1938, and 1946 events, as well as the eastern end of the 1957 rupture zone (Ryan and others, 2010). The authors proposed that a great earthquake of $\mathrm{M}_{\mathrm{W}} \sim 9.0$ may rupture a large section of the eastern Aleutian megathrust, noting that in order to generate an earthquake of this magnitude, it is necessary to rupture through multiple segments of the megathrust, including sections that may be weakly coupled. The authors also chose these particular sections of the megathrust because of the absence of any tectonic features that might work as barriers to the rupture. To construct a source model we place the largest amount of slip at the eastern end, which is a nearly fully locked segment of the megathrust beneath the Semidi Islands, based on GPS studies by Freymueller and others (2008). We assign a much smaller amount of slip to the middle part of the rupture, where coupling of the plate interface changes from about 30 percent locked at the Shumagin Islands to freely slipping west of the Shumagins (Fournier and Freymueller, 2007). The amount of slip increases again at the western end of the rupture, where little moment was released in 1957. This scenario is similar to the 1957 event that ruptured a long section of the megathrust with highly variable slip along strike (Johnson and others, 1994). The moment magnitude for this hypothetical event is 9.2.

\section{Seismic source model of a hypothetical tsunamigenic earthquake in the Yakutat Block}

Elliott (2011) proposed a regional tectonic model for the St. Elias orogen based on GPS measurements of the surface deformation. This model is based on data collected from 2005 through 2009 from 65 GPS sites in southeastern and south-central Alaska. The majority of these measurements were from newly established sites as part of the St. Elias Erosion/Tectonics Project (STEEP). Based on analyses from this dataset, the region was subdivided into three blocks (Elias, Icy Bay, and Yakutat) separated by four fault systems (or fault zones): the Malaspina-Pamplona system, the Yakataga-Chaix Hills system, the Foreland fault zone, and the decollement between the Yakutat block and the upper plate. The on-land fault locations were constrained with additional information from geologic maps, seismicity trends, and topographic features. Offshore locations of these fault zones, however, are not well constrained. The offshore continuation of the Malaspina-Pamplona and Yakataga-Chaix 


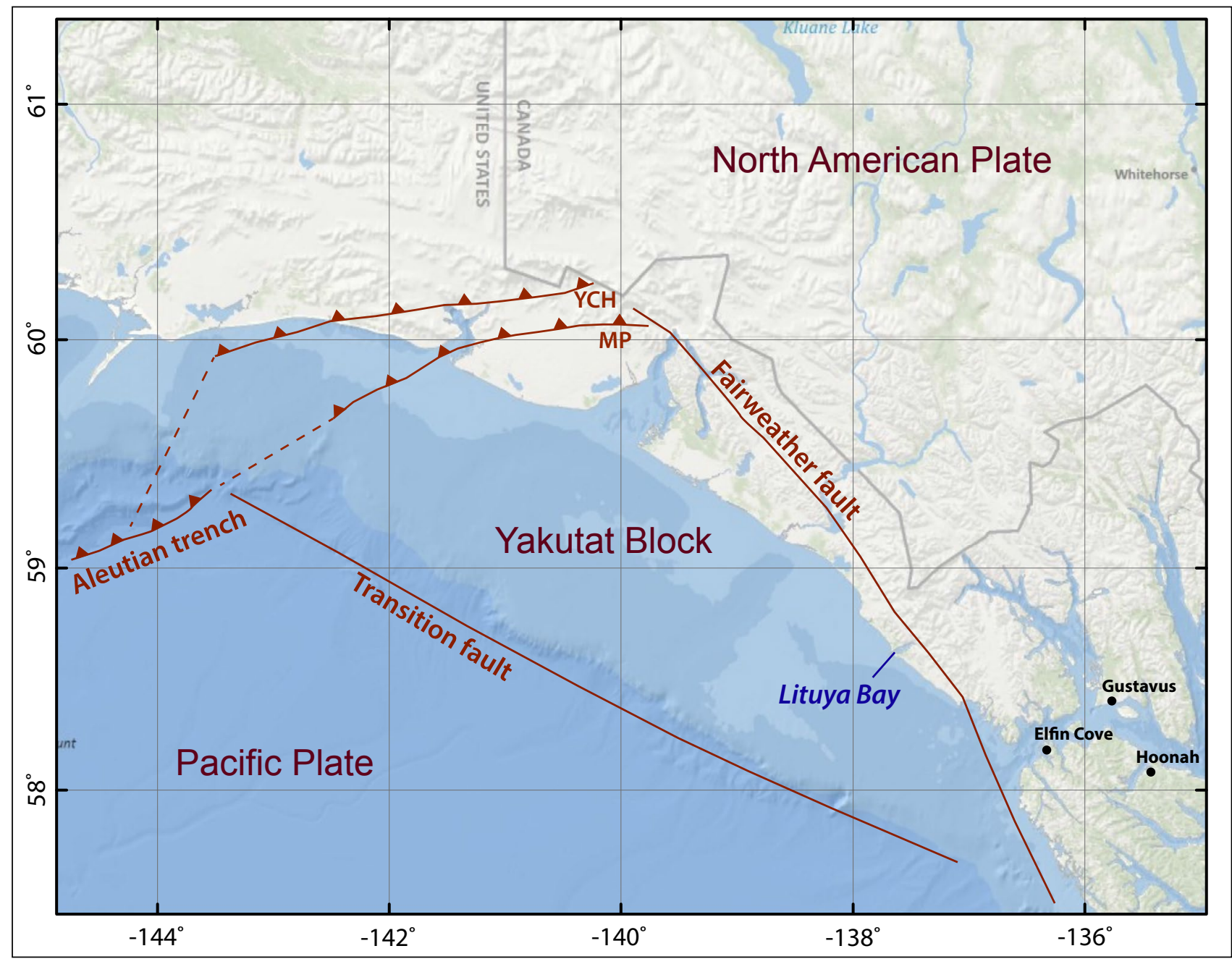

Figure 12. View of the Gulf of Alaska, showing major tectonic elements and communities of Elfin Cove, Gustavus, and Hoonah. Locations of the Malaspina-Pamplona (MP) fault system and the Yakataga-Chaix Hill (YCH) fault system are adopted from Elliott (2011).

Hill systems (Elliott, 2011) are shown in figure 12. While this tectonic model fits well-observed crustal motions and provides an integrated kinematic view of regional tectonics, many uncertainties remain regarding the depth and strike of identified fault features. Our preliminary modeling of hypothetical scenarios based on rupture of the offshore continuation of the Malaspina-Pamplona and Yakataga-Chaix Hills systems (with about 600 years of slip accumulation) indicate only a minor tsunami, with an amplitude less than $50 \mathrm{~cm}$ (1.6 ft), reaching Elfin Cove, Gustavus, and Hoonah. Therefore, there is no added value to this report from these scenarios. Moreover, more scientific research is needed to further constrain the offshore continuations of the onshore fault zones.

\section{Model of the Cascadia subduction zone earthquake}

Paleoseismic records indicate that great tsunamigenic earthquakes repeatedly occur on the Cascadia subduction zone, with irregular intervals averaging about 500 years (Atwater and others, 2004). The latest trans-Pacific tsunami generated by an earthquake at Cascadia occurred in January
1700 (Satake and others, 1996; Atwater and others, 2005). The impact of this tsunami on Alaska coastal communities was not documented, likely because of low population density along the Alaska coast at that time. Multiple models of Cascadia subduction zone ruptures are presented by Satake and others (2003) and Priest and others (2009), and by references they cite. These models describe hypothetical coseismic displacement fields with various levels of detail. Because a Cascadia subduction zone earthquake is considered to be a medium-field tsunami source to the southeastern Alaska coast, a relatively simple "worst-case credible" rupture of the Cascadia subduction zone is used in this report.

Scenario 7. Rupture of the Cascadia subduction zone, including portions of the margin along the British Columbia, Washington, Oregon, and northern California shore

Wang and others (2003) concluded that the down dip limit of the rupture in the 1700 Cascadia earthquake could not be constrained using tsunami heights recorded in Japanese historical records. The authors suggested a conservative approach for Cascadia coseismic deformation that assumed full coseismic rupture takes place over the entire locked zone 
and slip decreases linearly down dip to zero halfway into the present effective transition zone. A more recent model assumes that slip distribution in the down dip direction is bell-shaped (Witter and others, 2011). In this report, the assumed $\mathrm{M}_{\mathrm{W}} 9$ rupture recovers 1,200 years' worth of plate convergence with about $36 \mathrm{~m}(118 \mathrm{ft})$ of maximum slip (Witter and others, 2011).

\section{Source models of a hypothetical tsunamigenic earthquake in southeastern Alaska}

The Fairweather fault system intersects with the Transition fault zone just south of Cross Sound (figs. 2, 4, and 12). Gulick and others (2013) demonstrate that the Transition fault is a steeply dipping fault that shows strike-slip morphology on the sea floor. Doser and Lomas (2000) note that while there is some debate about seismic potential of the Transition fault zone, the 1973 earthquakes indicate that at least the southeastern end of the zone is seismically active. Perez and Jacob (1980) studied the July 1973 sequence of Cross Sound earthquakes and suggested that thrust faulting occurs at the eastern end of the Transition fault. The possible rate of right-oblique thrusting in this area was estimated by Lahr and Plafker (1980) as $4 \mathrm{~mm} /$ year (0.16 in/year), while Lundgren and others (1995) stated that the amount of oblique convergence on this fault could be no more than $2 \mathrm{~mm} /$ year $(0.08$ in/year), and $4 \mathrm{~mm} /$ year ( $0.16 \mathrm{in} /$ year) in the case of pure thrust. We constructed a source function for a $\mathrm{M}_{\mathrm{W}} 7.5$ thrust earthquake at the southern end of the Transition fault with an average slip of $1.8 \mathrm{~m}(5.9 \mathrm{ft})$ and calculated tsunami waves generated by this hypothetical rupture. Numerical results show that the waves reaching Elfin Cove are about $50 \mathrm{~cm}$ (1.6 ft) in amplitude, the maximum wave height at Gustavus is about $30 \mathrm{~cm}(1 \mathrm{ft})$, and the wave heights at Hoonah are on the order of $10 \mathrm{~cm}(0.3 \mathrm{ft})$. Therefore, we did not include this source in the list of hypothetical scenarios.

Another area in southeastern Alaska with tsunamigenic potential is the southern end of the Queen Charlotte fault (fig. 4). Following the proposed underthrusting model of the oblique convergence across the Queen Charlotte fault (Bustin and others, 2007) and the source mechanism of the recent $\mathrm{M}_{\mathrm{W}} 7.8$ Haida Gwaii earthquake of October 28, 2012, we assumed a hypothetical rupture in the southern part of the Haida Gwaii area on a 150-km-long (93-mi-long) subduction fault plane dipping at 28 degrees, with a strike equal to that of the Queen Charlotte fault. The moment magnitude for this event is 8.2 , assuming a value of $2.75 \times 1011 \mathrm{~Pa}$ for shear modulus (Suleimani and others, 2013). Leonard and others (2012) estimated a recurrence interval of events of similar magnitude in the Haida Gwaii area of about 800 years, under the assumption that there is no significant deformation of the Pacific plate. The authors note that accommodating even 2 $\mathrm{mm}(0.08 \mathrm{in})$ per year of convergence by internal shortening of the Pacific plate would increase this interval by about 30 percent. The results of our numerical modeling for this scenario indicate only a $30 \mathrm{~cm}(1 \mathrm{ft})$ tsunami reaching Elfin Cove, Gustavus, and Hoonah. Therefore, there is no added value to this report from the proposed hypothetical rupture in the Haida Gwaii area.

\section{LANDSLIDE TSUNAMI HAZARD POTENTIAL}

Tsunamis caused by underwater slope failures are a significant hazard in the fjords of coastal Alaska and other high-latitude fjord coastlines (Lee and others, 2006). Kulikov and others (1998) analyzed the tsunami catalog data for the North Pacific coast and showed that this region has a long record of tsunamis generated by submarine and subaerial landslides, avalanches, and rockfalls. For example, as a result of the 1964 earthquake numerous local submarine and subaerial landslide tsunamis were generated in Alaska, accounting for 76 percent of the tsunami fatalities (Lander 1996).

The coast of southeastern Alaska has numerous fjords. In a fjord setting, glacial rivers and streams form a delta at the fjord head and deposit sediment that can easily lose strength during earthquakes. A primary cause of submarine landslides in fjords is the accumulation of unconsolidated deposits on steep underwater slopes. Masson and others (2006) divide factors that contribute to initiation of submarine landslides into two groups: factors related to geologic properties of landslide material (such as overpressure due to rapid deposition); and those associated with external events (such as earthquakes or sea level change), noting that usually more than one factor contributes to a single landslide event. Hampton and others (1993) note that in a fjord environment, where deltaic sediment is deposited rapidly, the sediment builds up pore-water pressures and could liquefy under extreme low tide conditions or ground shaking during an earthquake, because of low static shear strength. While ground shaking is one of the most common triggering mechanisms for submarine slope failures, a close relationship has been demonstrated between coastal landslides and extreme low tides (Thompson and others, 2001; Kulikov and others, 1998). On November 3, 1994, a massive submarine landslide destroyed a timber dock on the east shore of Skagway harbor. The resultant wave killed one worker and damaged and destroyed boats and docks in the harbor, causing about \$2 million in damage. A numerical modeling study by Thompson and others (2001) demonstrated that the primary cause of the 1994 Skagway slide was the critical overloading of slope materials at a time of extreme low tide. Human activities can also trigger submarine landslides (Masson and others, 2006; Bornhold and others, 2001). With so many diverse mechanisms, assessment of landslide-generated tsunami hazard is a challenging task.

Fjords in southeastern Alaska are also prone to tsunamis generated by subaerial rockfalls caused by fractures in the bedrock along fjord sidewalls. Evans and Clague (1994) described the process of glacier unloading as an important mechanism that generates instability of rock slopes from relaxation of internal stress after deglaciation. Southeastern Alaska is a tectonically active area and earthquakes often trigger rock-slope failures in such environments. Although it is difficult to evaluate the contribution of a seismic event to the triggering of a rockfall, Cossart and others (2008) found that glacial unloading and associated stress release play an important role in triggering rock-slope failures. The 
largest known historical tsunami generated by a subaerial rock-slope failure was associated with an estimated 30 million $\mathrm{m}^{3}$ (1,050 million $\mathrm{ft} 3$ ) landslide in Lituya Bay (fig. 12), Alaska, on June 9, 1958. The slope failure was triggered by a M 7.9 earthquake on the nearby Fairweather fault (fig. 4). When the landslide entered the water it produced wave inundation of up to $530 \mathrm{~m}(1,740 \mathrm{ft})$ height on the opposite shore of the bay (Miller, 1960). A comprehensive study of an unstable rock slump on the northern shore of Tidal Inlet in Glacier Bay National Park,concluded that its rapid failure would result in significant tsunami hazard to park visitors (Wieczorek and others, 2007).

A tsunami hazard assessment study by Leonard and others (2012) was the first attempt to quantify tsunami hazard for the entire Canada coast. The study provided an overview of potential tsunami sources along the Pacific coast of Canada, including both tectonic and landslide sources. Leonard and others (2012) described several historical landslide tsunamis that occurred in fjords along the Pacific coast of North America. They concluded that the current knowledge of landslide tsunami sources in the fjords of the Pacific coast of Canada is not sufficient to perform probabilistic tsunami modeling of potential failures in the area. The analysis of submarine continental slope landslides has led to the conclusion that this hazard is negligible compared to other Pacific tsunami sources (Leonard and others, 2012). Nevertheless, it is known that massive landslides along continental slopes can cause great tsunamis. The Storegga Slide (Bryn and others, 2005) and the Grand Banks Slide (Fine and others, 2005) generated catastrophic tsunamis along the Norwegian and Canadian coastlines, respectively. Similarly, Grilli and others (2012) discuss the possibility of simultaneous generation of the 2011 Tohoku tsunami by both tectonic processes and submarine mass failures. In Alaska, the location of the submarine landslide that may have caused the $35 \mathrm{~m}(115 \mathrm{ft})$ wave runup at Unimak Island during the 1946 tsunami was recently identified using high-resolution seismic profiles (Miller and von Huene, 2013). The 1946 tsunami was probably generated by tectonic deformation and a submarine mass failure triggered by the earthquake, as earlier hypothesized by Fryer and Watts (2001). A valuable discussion of submarine mass wasting in Alaska is provided in Lee and others (2002), and numerical simulations of landslide-generated tsunamis along the Aleutian Arc are also described in Waythomas and others (2009).
One of the most probable triggering mechanisms for slope instability in southeastern Alaska is ground shaking associated with earthquakes. Slope failures can occur immediately during an earthquake, but also frequently happen after shaking stops, due to creep, reduction of shear stress, or an increase in pore pressure (Nadim, 2012). The updated probabilistic seismic hazard maps for Alaska (Wesson and others, 2007) indicate that, for the Icy Strait area, the values for peak ground acceleration (PGA) with a 2 percent probability of exceedance in 50 years range from $0.3 \mathrm{~g}$ to $0.8 \mathrm{~g}$, where $\mathrm{g}$ is gravitational acceleration. Slope stability analyses performed for fjords in Norway, an environment similar to southeastern Alaska, showed that much smaller values of PGAs are sufficient to trigger slides even on gentle 3-4 degree slopes (Lacasse and others, 2013). While it is known that earthquakes have triggered major submarine mass movements in many places around the world (Mather and others, 2014; Lastras and others, 2013; Lee and others, 2006; Hance, 2003a, 2003b; Kulikov and others, 1998), sitespecific slope stability analyses that integrate geophysical, geological, and geotechnical data are required to adequately assess slope stability hazards and their potential contribution to tsunami hazards.

\section{HYPOTHETICAL LANDSLIDE TSUNAMI SOURCES}

We consider several hypothetical landslide scenarios that could generate waves that could be potentially hazardous to the communities of Elfin Cove, Gustavus, and Hoonah. The hypothetical landslide scenario for Gustavus involves an unstable subaerial rock failure in Tidal Inlet (scenario 8), which has been identified and monitored by the USGS. Potential landslide tsunami sources for Elfin Cove and Hoonah include underwater slope failures in Taylor Bay (scenario 9) and in Port Frederick (scenario 10), respectively. Parameters of the hypothetical slides are listed in table 3. Unfortunately, there is no geotechnical information to constrain the locations and thicknesses of these potential underwater slides.

\section{Scenario 8. Underwater slide in Taylor Bay}

Taylor Bay is on the northern shore of Icy Strait in Glacier Bay National Park, at the terminus of Brady Glacier (fig. 2). Braided rivers run from the snout of the glacier into Taylor Bay, transporting and depositing sediment and making the outwash plain at Taylor Bay a source of fine-grained sand

Table 3. Hypothetical landslide scenarios used to model tsunami runup in Elfin Cove, Gustavus, and Hoonah.

\begin{tabular}{|c|l|c|c|c|}
\hline Scenario & \multicolumn{1}{|c|}{ Description } & $\begin{array}{c}\text { Volume } \\
\text { (million } \mathbf{~ m}^{\mathbf{3}} \text { ) }\end{array}$ & $\begin{array}{c}\text { Maximum slide } \\
\text { thickness } \mathbf{( m )}\end{array}$ & $\begin{array}{c}\text { Maximum wave } \\
\text { height (m) }\end{array}$ \\
\hline 8 & $\begin{array}{l}\text { Underwater slide in } \\
\text { Taylor Bay }\end{array}$ & 0.5 & 23 & 2 \\
\hline 9 & $\begin{array}{l}\text { Subaerial rockslide in } \\
\text { Tidal Inlet }\end{array}$ & 3 & 26 & 6 \\
\hline 10 & $\begin{array}{l}\text { Underwater slide in } \\
\text { Port Frederick }\end{array}$ & 2.9 & 33 & 5.4 \\
\hline
\end{tabular}


and silt (KellerLynn, 2009). The delta of the outwash plain in Taylor Bay is a probable location of a potential submarine landslide. After determining the location of a potential slide and defining the failure surfaces to constrain the slide volume, we made a hypothetical slide scenario that has an estimated volume of $0.1 \mathrm{~km}^{3}\left(130\right.$ million $\left.\mathrm{yd}^{3}\right)$. The thickness of the slide and its location are shown in figure 13.

\section{Scenario 9. Subaerial rockslide in Tidal Inlet}

An unstable rock slump has been identified adjacent to the northern shore of Tidal Inlet in Glacier Bay National Park (fig. 14). The slump was thoroughly investigated to assess hazards from landslide-generated tsunami waves, and associated risk to cruise ships and other park visitors (Wieczorek and others, 2007). It was concluded that a large subaerial rockfall entering Tidal Inlet has the potential to generate a local tsunami that could impact the western arm of Glacier

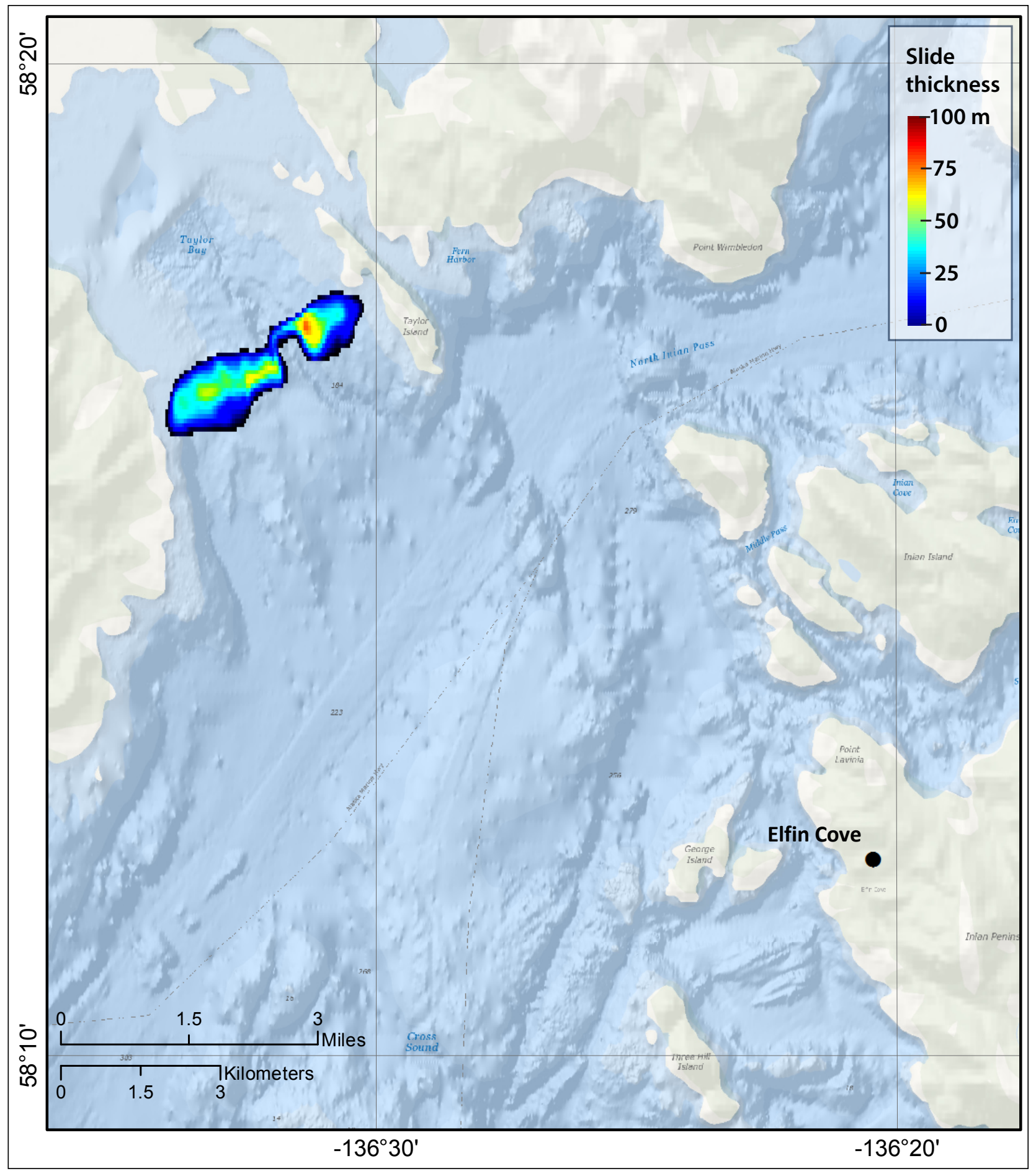

Figure 13. Illustration showing initial thickness of the Taylor Bay slide (scenario 8). 


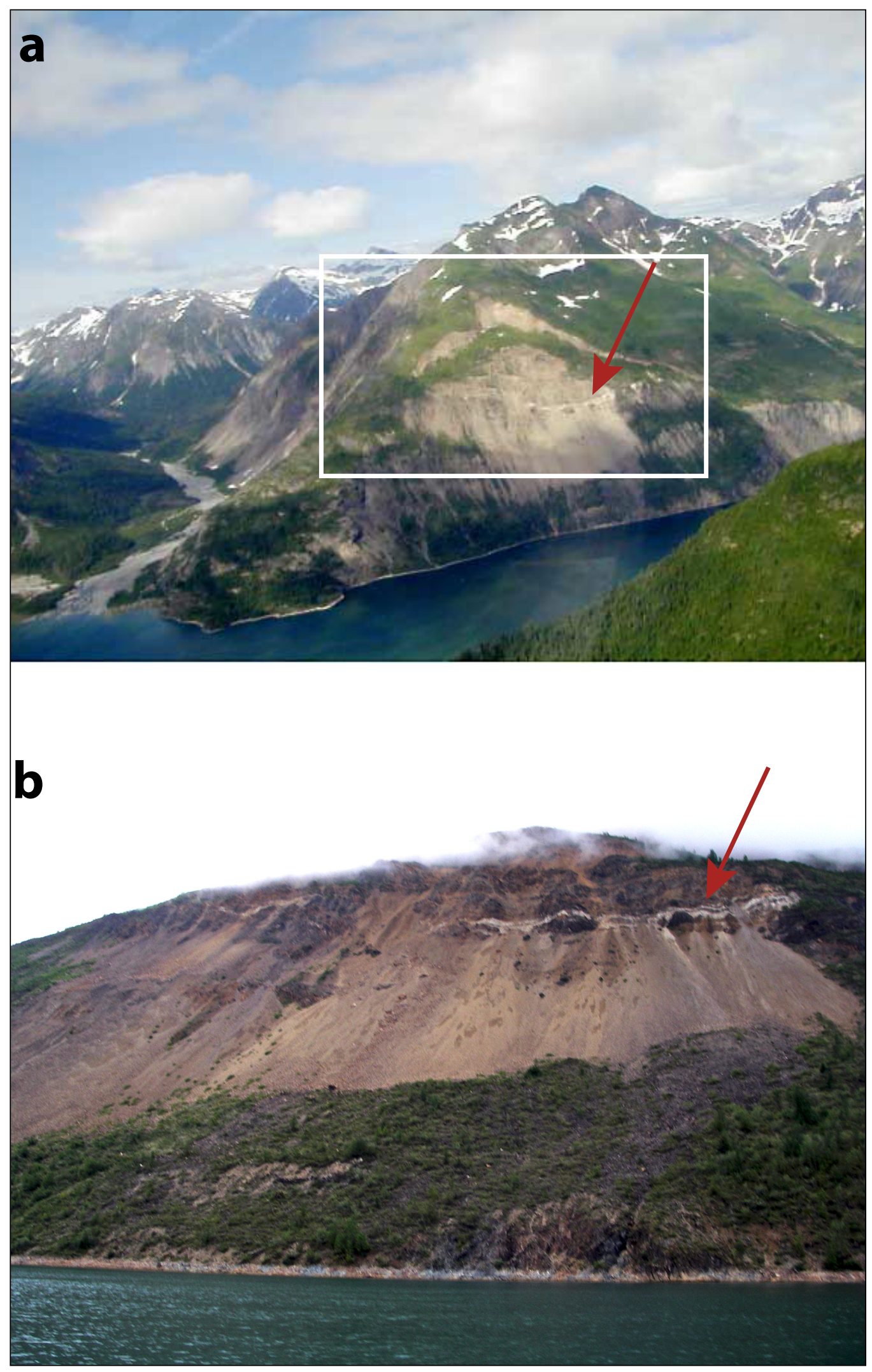

Figure 14. a. Location of the potential slide on the northern shore of Tidal Inlet. White box outlines the upper portion of the landslide (Wieczorek and others, 2007). b. View of the slide from Tidal Inlet (photo by Joel Curtis). On both photos, red arrow shows a white layer of possible limestone (Wieczorek and others, 2007). 
Bay with significant wave action, possibly lasting for several hours. Figure 14 shows the detached landslide mass sitting above the northern shore of Tidal Inlet. Detailed description of the slide as well as the estimated slide parameters are given in Wieczorek and others (2007). To provide guidance to local emergency officials in Gustavus, we numerically modeled local tsunamis that could be generated by this subaerial rock slump and calculated inundation and tsunami time histories at Gustavus. The total volume of the slide is approximately $0.03 \mathrm{~km}^{3}\left(39\right.$ million $\left.\mathrm{yd}^{3}\right)$.

\section{Scenario 10. Underwater slide in Port Frederick}

A delta at the mouth of Humpback Creek on the western shore of Port Frederick, west of the community of Hoonah, is another possible location of a submarine landslide. After determining the location for a potential slide and defining the failure surfaces to constrain the slide volume, we made a hypothetical slide scenario that has an estimated volume of $0.1 \mathrm{~km}^{3}\left(130\right.$ million $\left.\mathrm{yd}^{3}\right)$. The thickness of the slide and its location are shown in figure 15 .

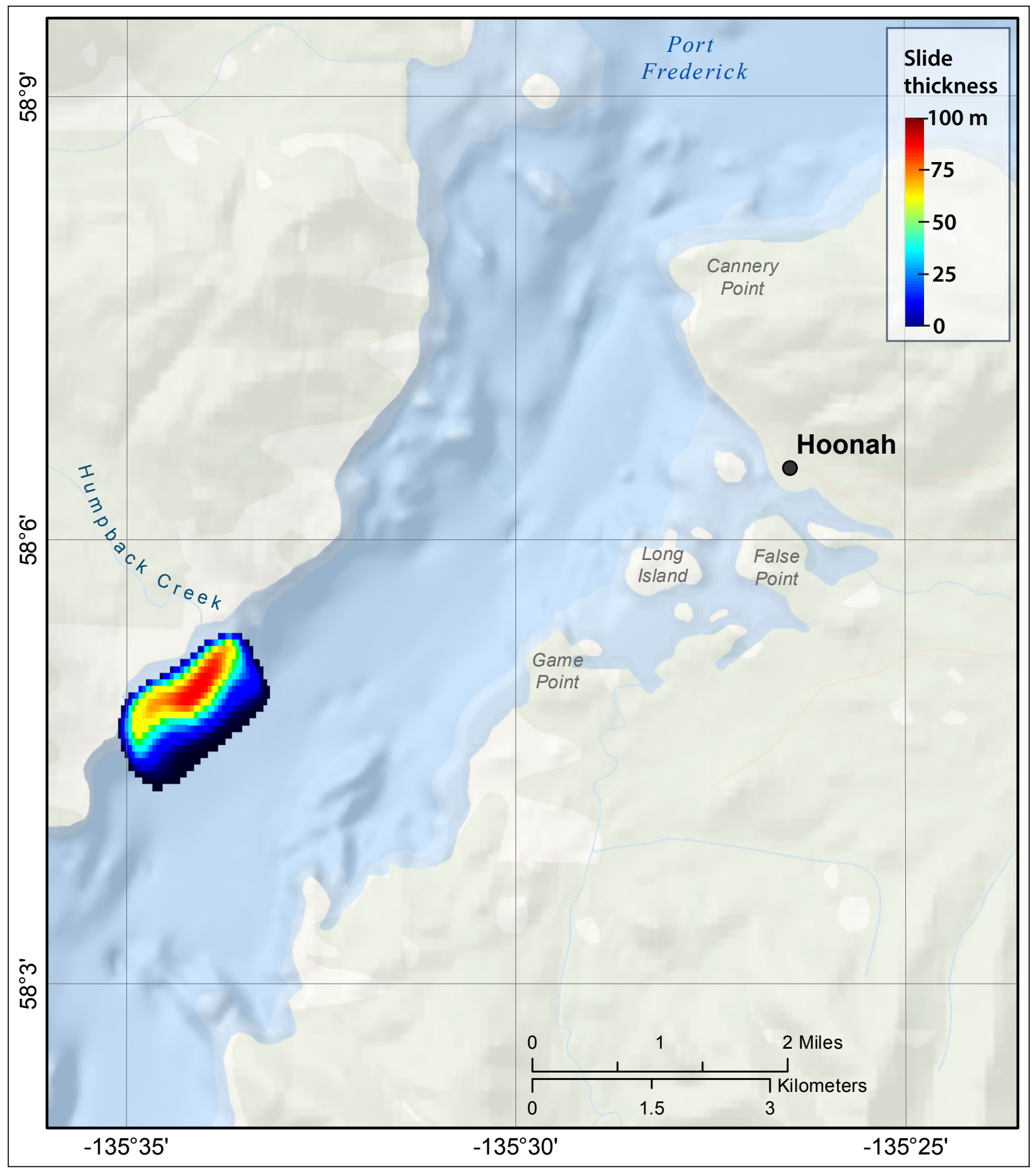

Figure 15. Illustration showing initial thickness of the slide in Port Frederick, off the delta of Humpback Creek (scenario 10). 


\section{MODELING RESULTS}

\section{RESULTS OF HYPOTHETICAL TSUNAMI SCENARIOS}

We performed numerical calculations for all of the hypothetical scenarios described above (tables 2 and 3). In each case, we modeled the water dynamics in each grid listed in table 1, and computed the extent of inundation and flow depths for each community only in the highest-resolution grid. According to the modeling results, tsunami sources in the Gulf of Alaska (scenarios 1-4) have the most significant effect on the communities in Icy Strait, with scenario 3 producing the largest waves at every location. The next largest event in terms of tsunami amplitudes is a rupture in the Cascadia subduction zone (scenario 5). The tsunami sources in the area of Alaska Peninsula (scenarios 5 and 6) produce comparable or slightly smaller waves. The effects of landslide tsunami scenarios are community specific. Below we discuss results of numerical modeling of tectonic and landslide scenarios, presenting the maximum composite tsunami flow depth maps for each community. Note that the tsunami flow depth is one of the important indicators of potential damage, and must be differentiated from runup height (Synolakis and Bernard, 2006).

\section{Elfin Cove}

The Elfin Cove inundation map (fig. 16) is a composite flow depth map that combines effects of all tectonic and landslide scenarios. It includes all community buildings and facilities inside the bay. Significant inundation occurs in the area of Memorial Park between the fuel dock and the barge landing. This piece of land gets flooded with flow depths up to $3 \mathrm{~m}(10 \mathrm{ft})$. The inundation of the coast inside the bay is not significant.

To better understand different effects of tectonic and landslide-generated waves at Elfin Cove, we separately plot maximum composite wave heights for all tectonic scenarios (fig. 17), and for the landslide scenario (fig. 18). The plots show that the tsunami energy field is different for tectonic and landslide tsunamis. The tectonic scenarios produce long waves and a relatively uniform energy field in Elfin Cove and in the surrounding waters, while the landslide waves result in much shorter waves and in energy concentration at the entrance into the cove. Maximum wave heights resulting from landslide waves are slightly greater in this area, which explains the larger flow depths in this section of the coastline. At the same time, landslide waves do not penetrate into the cove, where inundation is caused only by tectonic waves.

Comparison of tsunami amplitudes for tectonic and landslide scenarios at Elfin Cove tide gauge (point 5 in fig. A1) shows that the wave generated by scenario 8 , the Taylor Bay slide, is comparable with the largest tectonic wave that results from scenario 3 (figs. A3 and A5). The greatest difference is in the magnitude of tsunami currents. Scenario 8 produces stronger wave currents (about $2 \mathrm{~m} / \mathrm{sec}$ ) at Elfin Cove for a few minutes following the arrival of the landslide-generated wave from Taylor Bay.

\section{Gustavus}

The Gustavus inundation map (fig. 19) covers the entire community on the shore of Icy Strait, as well as several facilities such as the power plant, lodge, and docks in Bartlett Cove (inset map B). The inundation occurs along the Icy Strait shore, adjacent to the intertidal zone, and around the mouth of Salmon River. Flow depths in this area range from 0.5 to $2.5 \mathrm{~m}$ (1.6 to $8.2 \mathrm{ft})$. The maximum flow depths of about $3 \mathrm{~m}$ ( $\sim 10 \mathrm{ft}$ ) occur at the mouth of a creek that is west of Salmon River, but this area is uninhabited. In the Bartlett Cove area, inundation with flow depths of about $2.5 \mathrm{~m} \mathrm{(} \sim 8 \mathrm{ft})$ occurs east of the public dock, but the inundation does not reach the lodge and the cabins. Another inundated area is around the dock at Glacier Bay National Park headquarters, but the park facilities are at a higher elevation and do not get flooded. The greatest flow depths occur in an uninhabited area on the northeastern shore of Lagoon Island, and across the inlet to the east of the island. The plot of composite maximum wave heights for all tectonic scenarios (fig. 20) shows that the area of largest tsunami energy is in Icy Passage, east of Gustavus. Another area of higher tsunami amplitudes is Bartlett Cove. This energy distribution pattern explains why the coastline adjacent to the community experiences lesser inundation.

We do not provide the maximum wave height plot for the landslide scenario at Gustavus because the effects of the rockslide in Tidal Inlet (scenario 9) are negligible. While the initial rockslide-generated wave has amplitude of about $14 \mathrm{~m}$ (46 ft) at the entrance to Tidal Inlet (point A in fig. A2), it dissipates quickly, and the amplitude drops to $0.5 \mathrm{~m}$ (1.6 ft) just $25 \mathrm{~km}$ (15.5 mi) from Glacier Bay (point B in fig. A2). These results are consistent with the conclusions of Wieczorek and others (2007), whose numerical modeling study indicated that significant waves will only be observed at the mouth of Tidal Inlet, and that the wave energy diminishes quickly.

\section{Hoonah}

The Hoonah inundation map (fig. 21) covers most of the town on the eastern shore of Port Frederick, and also the northern part of the community in the area of Ward Cove (inset map B), where the Indian cemetery and the cannery are located. The maximum inundation line in Hoonah is calculated as a composite inundation from tectonic and landslide scenarios. However, the only scenario that resulted in significant inundation around the small-boat harbor is scenario 10, which is an underwater slide off the delta front on the western shore of Port Frederick, at the delta of Humpback Creek (fig. 15). The harbor's breakwater gets flooded with flow depths of about $1.5 \mathrm{~m}(4.5 \mathrm{ft})$. Comparison of the composite maximum wave heights for the tectonic scenarios (fig. 22) and for the landslide scenario (fig. 23) confirms that local landslide-generated waves are a major threat to the community. Similar to Elfin Cove, the tectonic scenarios produce long waves and a relatively uniform energy field in Port Frederick with maximum amplitudes on the order of 2 $\mathrm{m}(6.5 \mathrm{ft})$, while the landslide waves result in much shorter waves and higher tsunami amplitudes, up to $4 \mathrm{~m}(13 \mathrm{ft})$ at only certain locations. Landslide tsunami energy is concentrated 


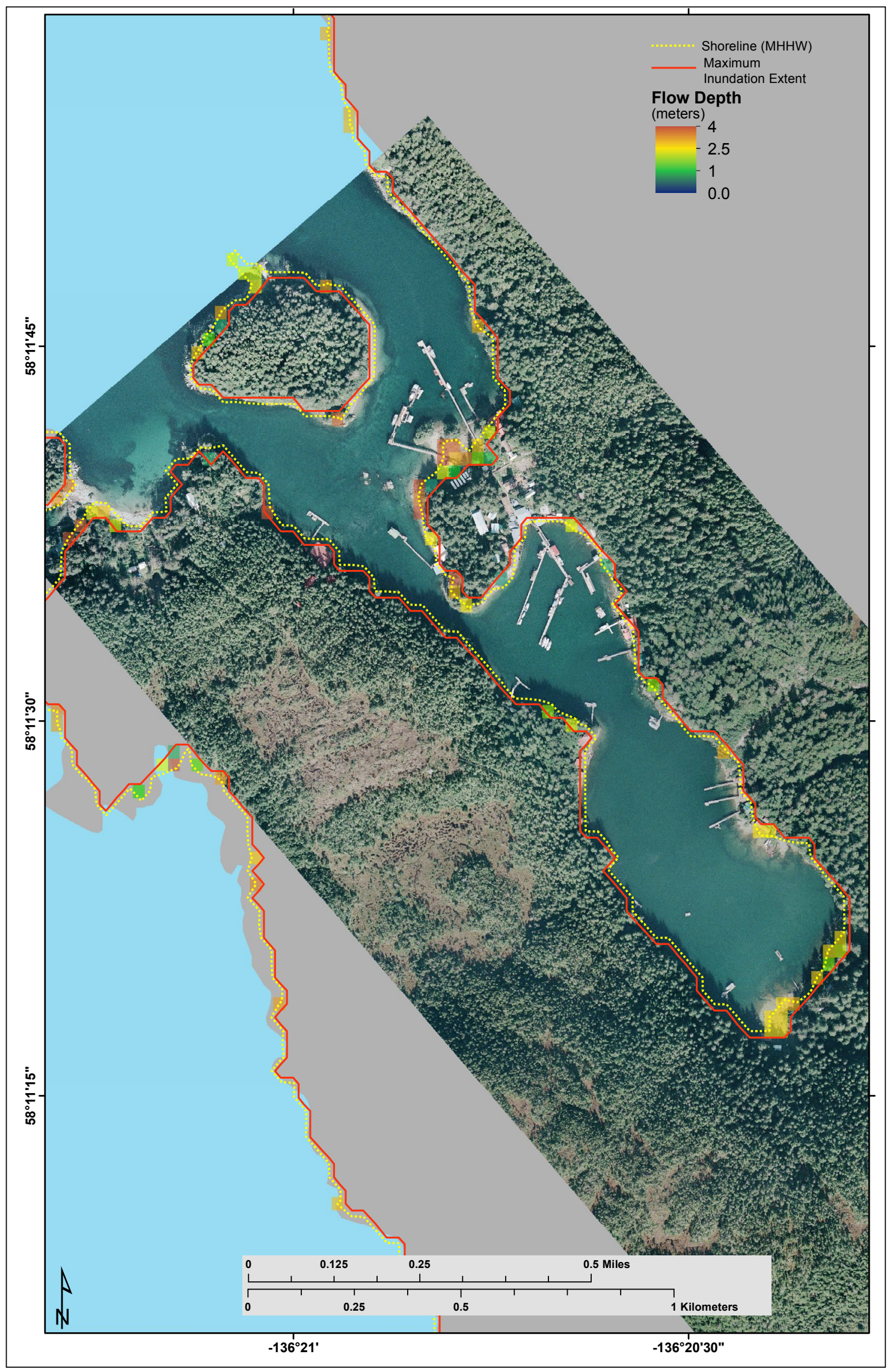

Figure 16. Maximum composite potential inundation extent for all scenarios, and maximum composite flow depths over dry land in Elfin Cove. The shoreline corresponds to the present-day MHHW datum. 


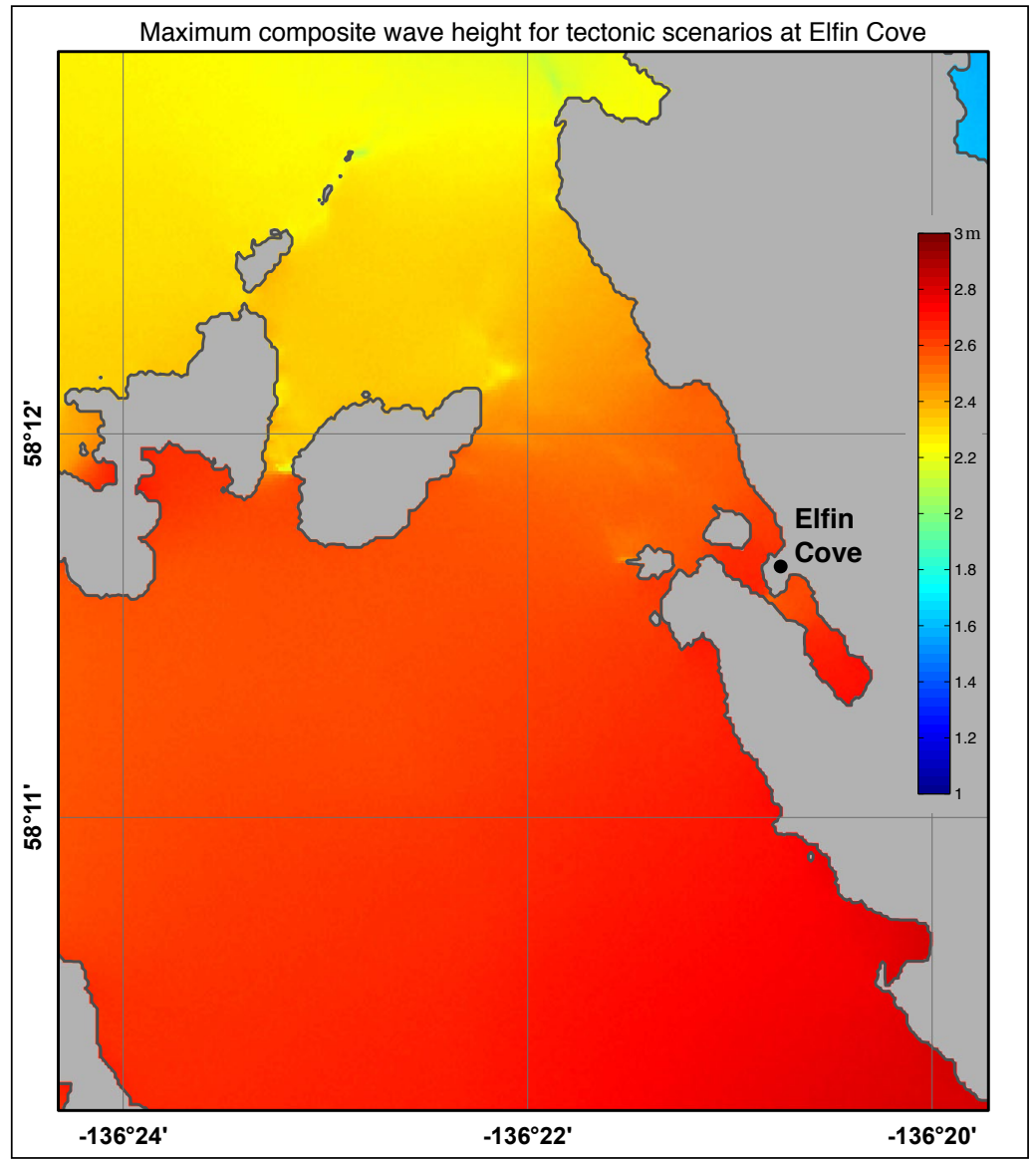

Figure 17. Maximum composite wave height for tectonic scenarios at Elfin Cove.

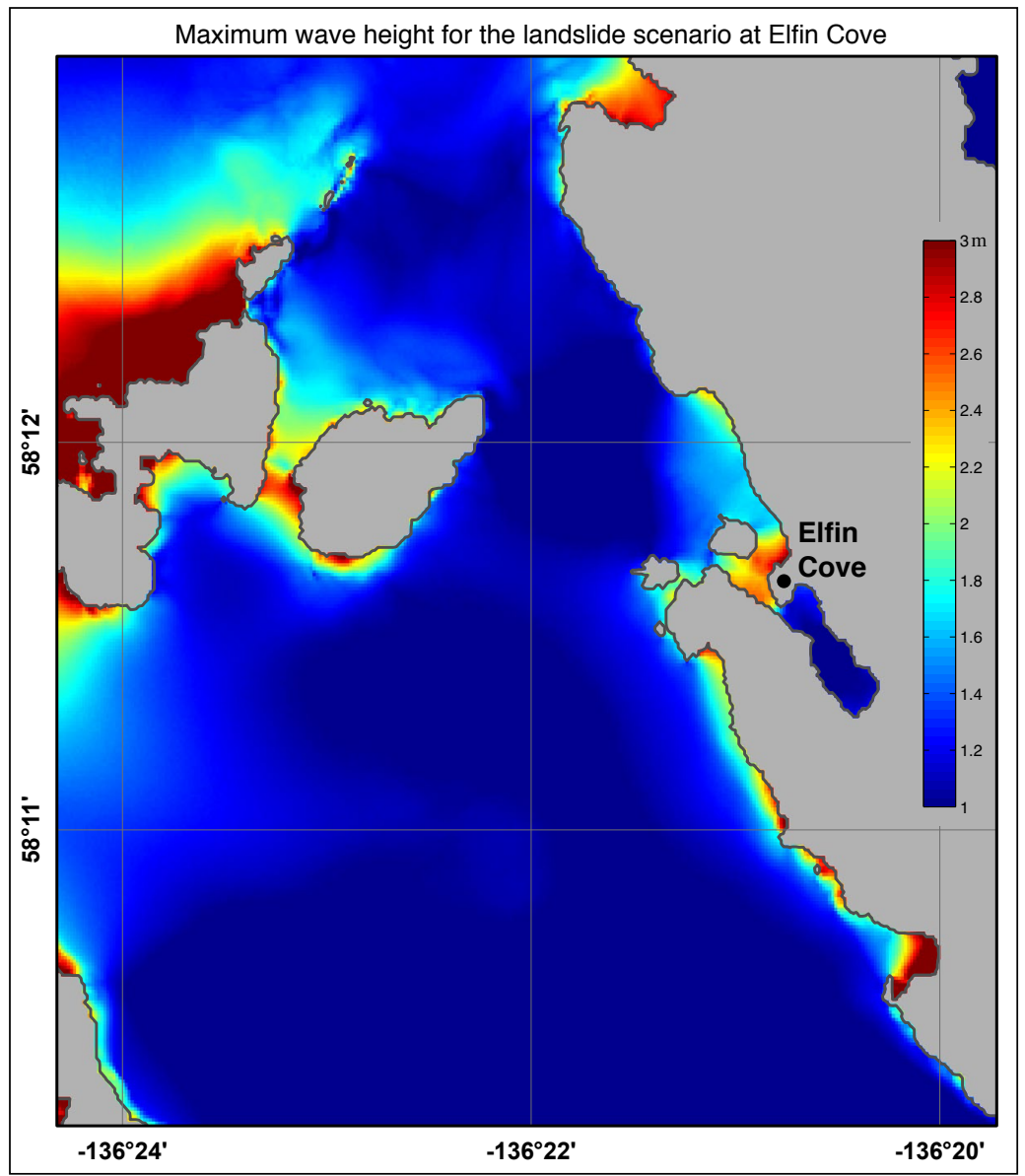

Figure 18. Maximum wave height for the landslide scenario at Elfin Cove. 


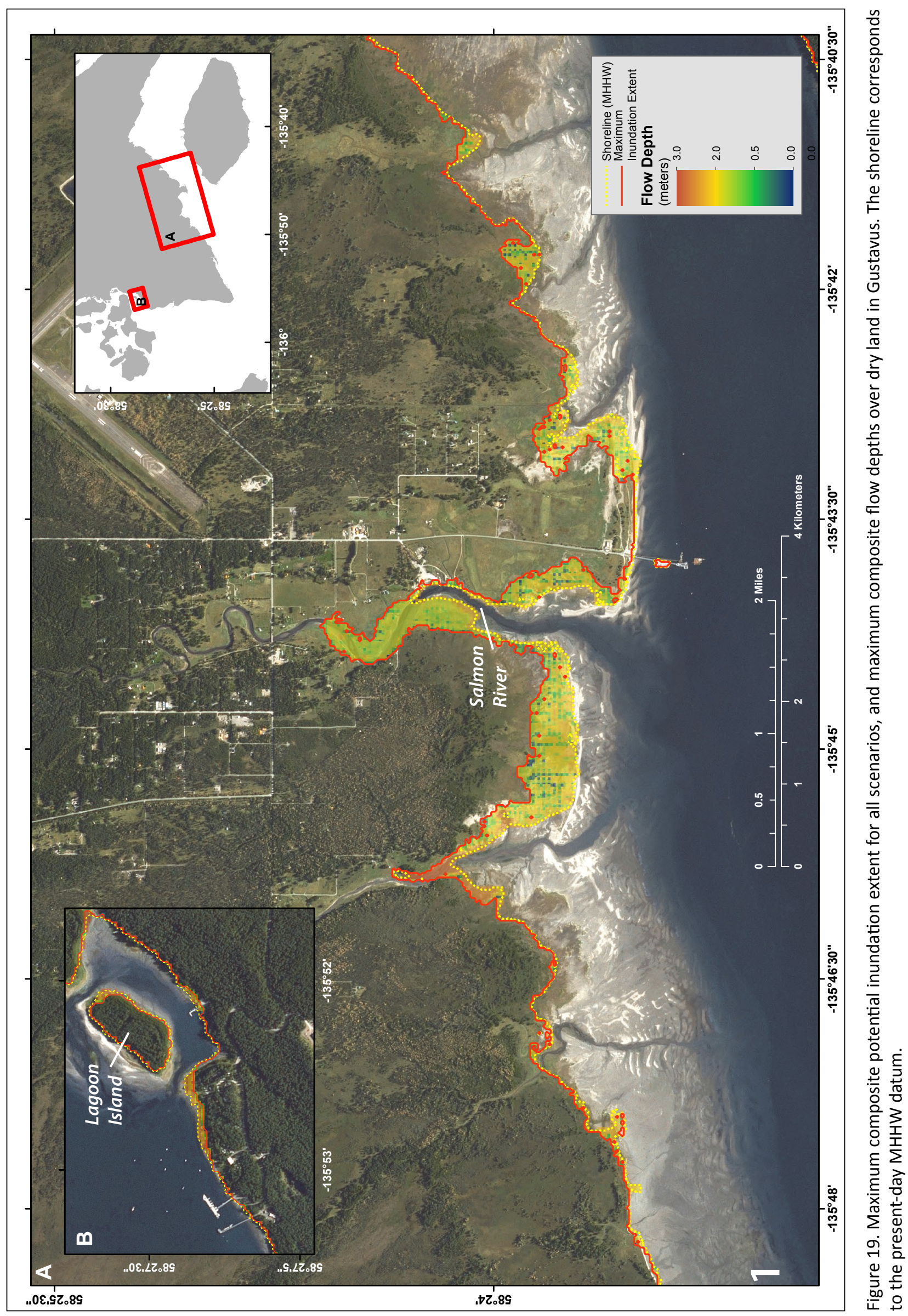




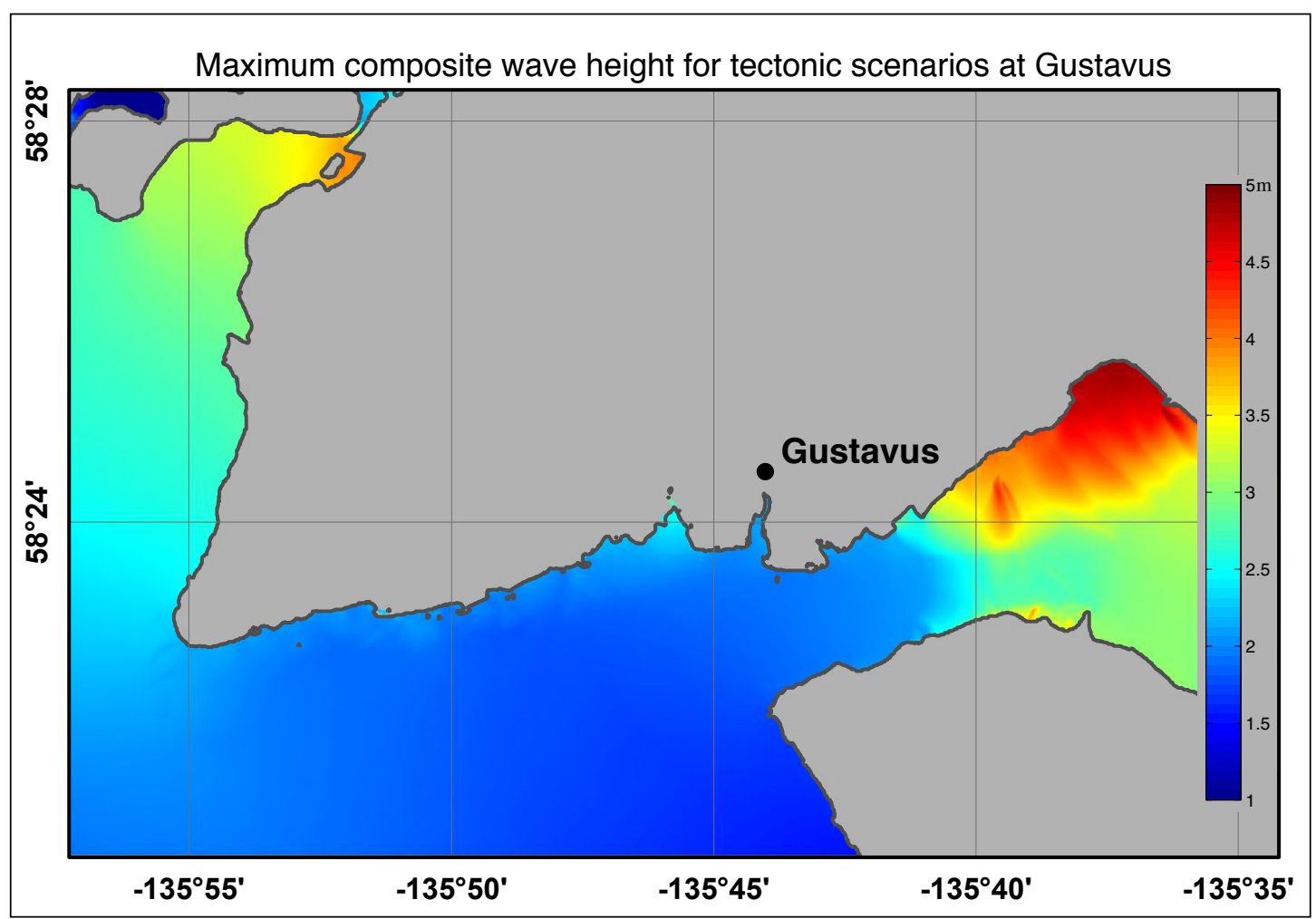

Figure 20. Maximum composite wave height for tectonic scenarios at Gustavus.

around the breakwaters and along the shoreline between the harbor and Ward Cove.

We compared tsunami amplitudes for tectonic and landslide scenarios at two locations: inside the boat harbor and at the warehouse (points 13 and 14 in fig. C1). Figures $\mathrm{C} 2$ and C3 show the tectonic tsunami time series for sea level and velocity, and figure $\mathrm{C} 4$ presents the same for the landslide scenario. The comparison shows that the landslide-generated wave has a smaller amplitude than the largest tectonic wave, but it arrives within 10 minutes and produces stronger currents.

\section{TIME SERIES AND OTHER NUMERICAL RESULTS}

To provide a more accurate assessment of tsunami hazards, we have supplemented the inundation maps with the time series of the modeled water level and velocity dynamics at certain locations in the communities. The time of arrival of the first wave, the maximum wave amplitude, and the duration of wave action are important factors that should be considered by emergency managers during evacuation planning. Appendices A, B, and C contain plots of sea level and velocity time series for selected scenarios at selected critical locations in Elfin Cove, Gustavus and Hoonah, respectively (table 4). The zero time corresponds to the epicenter origin time and elevations correspond to the post-earthquake MHHW datum. Velocity magnitude is calculated as water flux divided by water depth, thus the velocity value can have large uncertainties if the water depth is low. In the plots shown, velocity is computed only where the water depth is greater than $0.1 \mathrm{~m}(0.3 \mathrm{ft})$.

\section{SOURCES OF ERRORS AND UNCERTAINTIES}

The hydrodynamic model used to calculate tsunami propagation and runup is a nonlinear, flux-formulated, shallow-water model (Nicolsky and others, 2011; Nicolsky, 2012). The model passed the verification and validation tests required for numerical codes used in production of tsunami inundation maps (Synolakis and others, 2007; National Tsunami Hazard Mitigation Program [NTHMP], 2012).

The source mechanism remains the biggest unknown in our tsunami modeling and hazard evaluation. Since the initial condition for the modeling is determined by the displacement of the ocean bottom, the largest source of errors is the earthquake model. When the tsunami is generated in the vicinity of the coast, the direction of the incoming waves, their amplitudes, and times of arrival are determined by the initial displacements of the ocean surface in the source area because the distance to the shore is too small for the waves to disperse. Therefore, near-field inundation modeling results are especially sensitive to the fine structure of the tsunami source. The modeling process is highly sensitive to errors when the complexity of the source function is combined with its proximity to the coastal zone. Finally, we note that the horizontal resolution of the grid used for inundation modeling is $15 \mathrm{~m}$ (49 ft). This scale is limited by the resolution of the topographic and bathymetric data used for grid construction. The $15 \mathrm{~m}(49 \mathrm{ft})$ resolution is high enough to describe major relief features, but the existing model cannot accurately resolve small topographic features, buildings, and other facilities. 


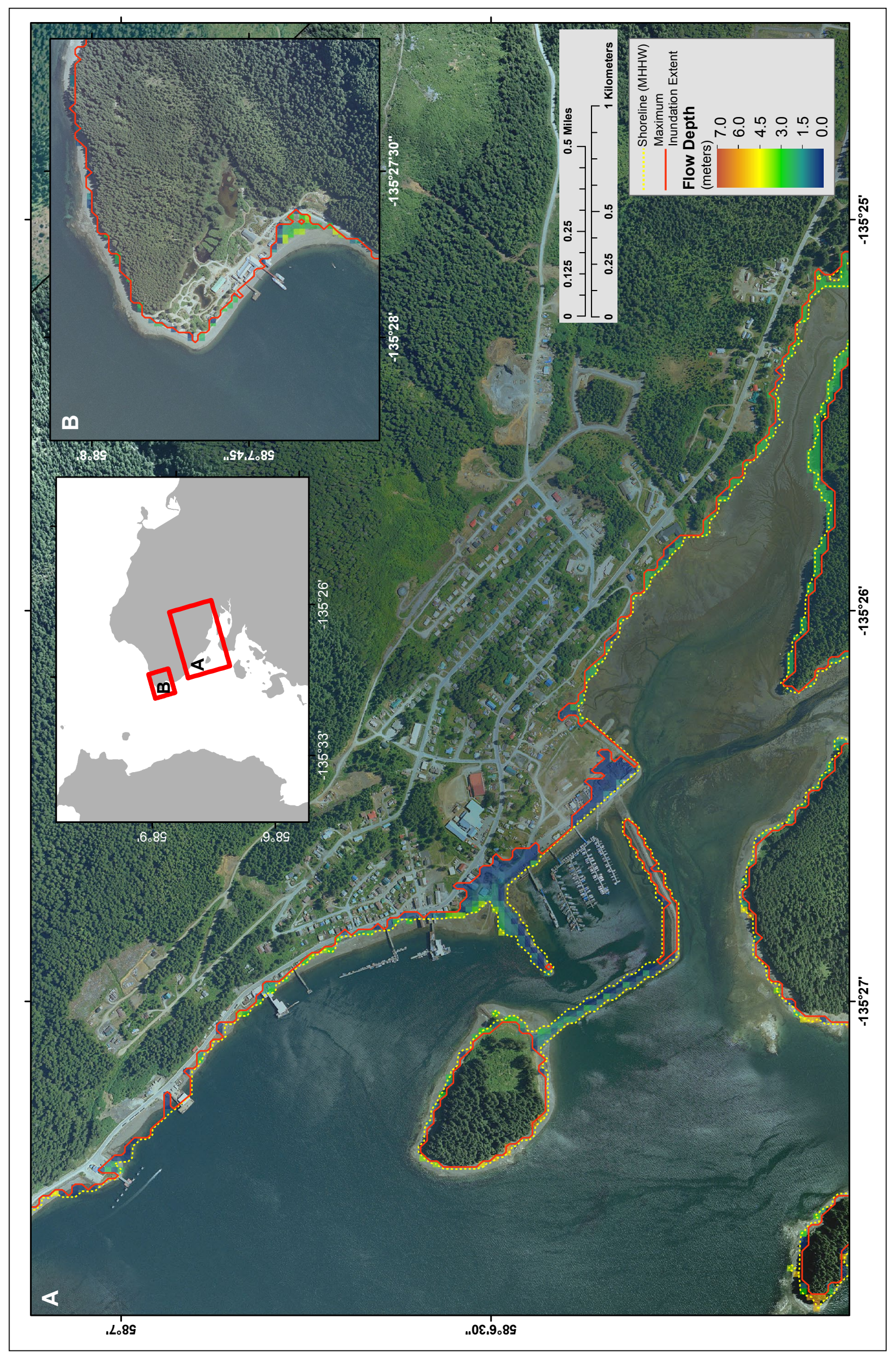

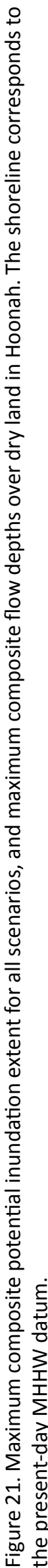




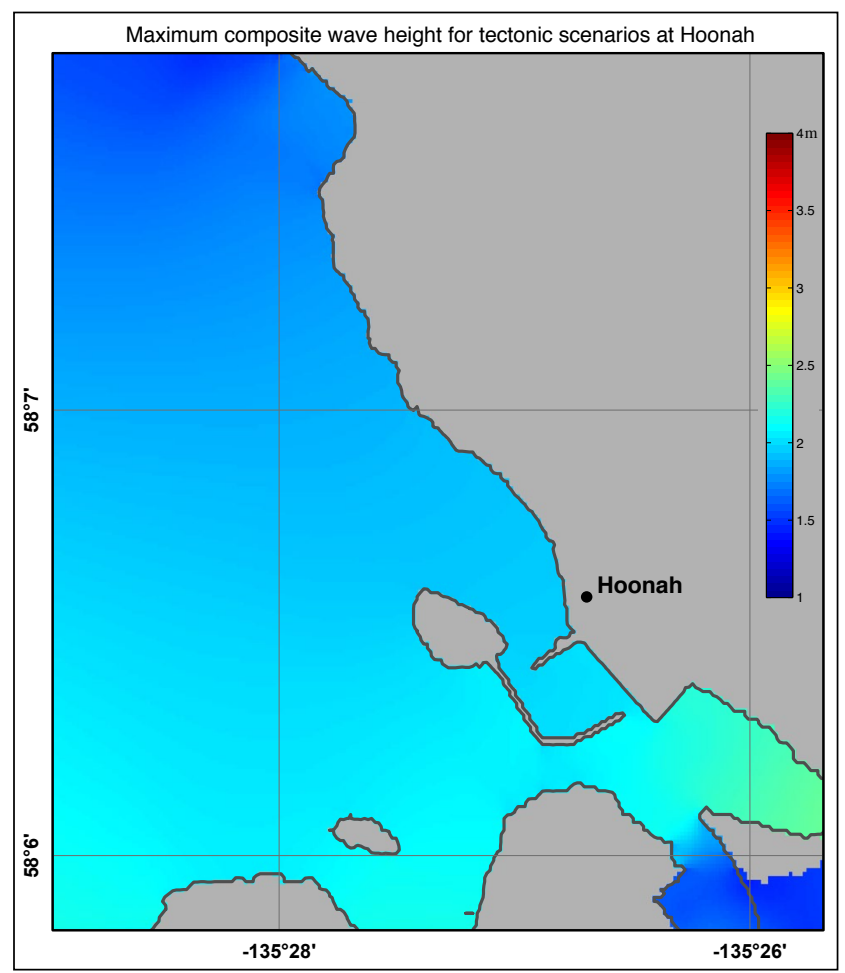

Figure 22. Maximum composite wave height for tectonic scenarios at Hoonah.

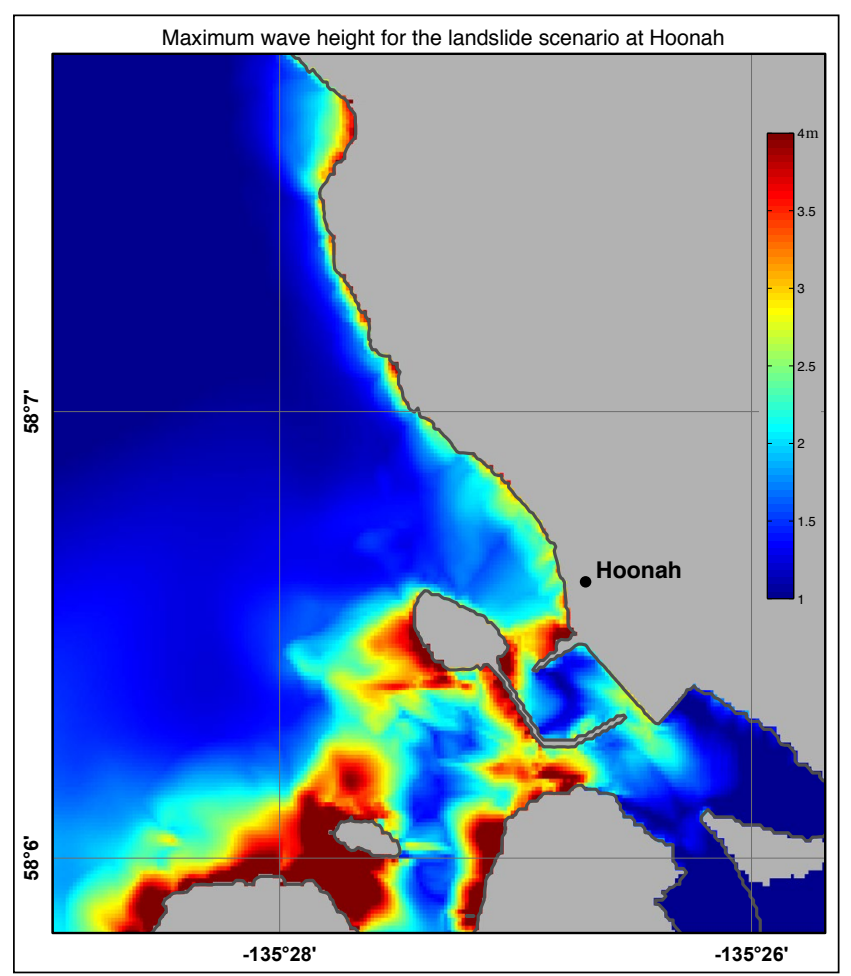

Figure 23. Maximum wave height for the landslide scenario at Hoonah.

Table 4. Figures in appendices A, B, and C that display locations of time series points and calculated time series for Elfin Cove, Gustavus, and Hoonah.

\begin{tabular}{|l|c|c|c|}
\hline \multicolumn{1}{|c|}{ Community } & $\begin{array}{c}\text { Locations of time } \\
\text { series points }\end{array}$ & $\begin{array}{c}\text { Time series for } \\
\text { tectonic scenarios }\end{array}$ & $\begin{array}{c}\text { Time series for } \\
\text { landslide scenarios }\end{array}$ \\
\hline Elfin Cove & A-1, A-2 & A-3, A-4 & A-5 \\
\hline Gustavus & B-1, A-2 & B-2, B-3 & B-4 \\
\hline Hoonah & C-1 & C-2, C-3 & C-4 \\
\hline
\end{tabular}

\section{SUMMARY}

We present the results of numerical modeling of earthquake-generated tsunamis for the communities of Elfin Cove, Gustavus, and Hoonah in southeastern Alaska. The maps that are part of this paper have been completed using the best information available and are believed to be accurate; however, their preparation required many assumptions. We have considered several tsunami scenarios and have provided an estimate of maximum credible tsunami inundation, which is based on the best available scientific knowledge and data and is considered to be a conservative estimate of the potential hazard. Actual conditions during a tsunami event may vary from those considered, so the accuracy cannot be guaranteed. The limits of inundation shown should only be used as a guideline for emergency planning and response action. Actual areas inundated will depend on specifics of earth deformations, on-land construction, and tide level, and may differ from areas shown on the map. The information on this map is intended to permit state and local agencies to plan emergency evacuation and tsunami response actions in the event of a major tsunamigenic earthquake. These results are not intended for land-use regulation.

\section{ACKNOWLEDGMENTS}

This project was supported by the National Oceanic and Atmospheric Administration (NOAA) under Reimbursable Service Agreement ADN 0931000 with the State of Alaska's Division of Homeland Security and Emergency Management. Some of the research in this publication is sponsored by the Cooperative Institute for Alaska Research with funds from NOAA under cooperative agreement NA08OAR4320751 with the University of Alaska. Numerical calculations for this work were supported by a grant of High Performance Computing (HPC) resources from the Arctic Region Supercomputing Center (ARSC) at the University of Alaska Fairbanks. We thank Chris Waythomas and Isaac Fine for their reviews that improved the report and maps. 


\section{REFERENCES}

Alaska Department of Commerce, Community, and Economic Development (Community and Regional Affairs), 2013, Elfin Cove Community Profile, http:// commerce.alaska.gov/cra/DCRAExternal/community/ Details/95e65a3f-7d2b-468f-9750-94e0c5c647b8, Community Database Online.

Alaska Department of Commerce, Community, and Economic Development (Community and Regional Affairs), 2013, Gustavus Community Profile, http:// commerce.alaska.gov/cra/DCRAExternal/Community/ Details/74866bc7-44d7-4184-9c42-2bf36bea4fec, Community Database Online.

Alaska Department of Commerce, Community, and Economic Development (Community and Regional Affairs), 2013, Hoonah Community Profile, http:// commerce.alaska.gov/cra/DCRAExternal/Community/ Details/7b1783c7-a548-47fe-b944-dc9bb6ebfc0d, Community Database Online.

AEIC event page; http://www.aeic.alaska.edu/quakes/ queen_charlotte_20130105.html

Arakawa, Akio, and Lamb, V.R., 1981, A potential enstrophy and energy conserving scheme for the shallow water equations: Monthly Weather Review, v. 109, p. 18-36.

Assier-Rzadkiewicz, S., Mariotti, C., and Heinrich, P., 1997, Numerical simulation of submarine landslides and their hydraulic effects: Journal of Waterway, Port, Coastal, and Ocean Engineering, v. 123, no. 4, p. 149-157.

Atwater, B.F., Tuttle, P.F., Schweig, E.S., Rubin, C.M., Yamaguchi, D.K., and Hemphill-Haley, Eileen, 2004, Earthquake recurrence inferred from paleoseismology, in Gillespie A.R., Porter, S.C., and Atwater, B.F., eds., The Quaternary Period in the United States: New York, Elsevier Science, p. 331-350.

Atwater, B.F., Musumi-Rokkaku, Satoku, Satake, Kenji, Tsuji, Yoshinobu, Ueda, Kazue, and Yamaguchi, D.K., 2005, The orphan tsunami of 1700-Japanese clues to a parent earthquake in North America: U.S. Geological Survey Professional Paper 1707 (prepared in cooperation with the Geological Survey of Japan, the University of Tokyo, and the University of Washington, and published in association with University of Washington Press), 133 p.

Bornhold, B.D., Thomson, R.E., Rabinovich, A.B., Kulikov, E.A., and Fine, I.V., 2001, Risk of landslide-generated tsunamis for the coast of British Columbia and Alaska, in Mahmoud, M., van Everdingen, R., and Carss, J., eds., An earth odyssey-Proceedings of the 54th Canadian Geotechnical Society Conference: Richmond, B.C., Bitech Publishers, Ltd., p. 1,450-1,454.

Bryn, P., Berg, K., Forsberg, C.F., Solheim, A., and Kvalstad, T.J., 2005, Explaining the Storegga slide: Marine and Petroleum Geology, v. 22, p. 11-19. doi:10.1016/j. marpetgeo.2004.12.003

Bustin, A.M.M., Hyndman, R.D., Kao, H., and Cassidy, J.F., 2007, Evidence for underthrusting beneath the Queen Charlotte margin, from teleseismic receiver function analysis: Geophysical Journal International, v. 171, no. 3, p. 1,198-1,211. doi:10.1111/j.1365-246X.2007.03583.x Caldwell, R.J., Taylor, L.A., Eakins, B.W., Carignan, K.S., and Collins, S.V., 2012, Digital elevation models of Juneau and Southeast Alaska-Procedures, data sources and analysis: National Geophysical Data Center, NOAA Technical Memorandum NESDIS NGDC-53, $66 \mathrm{p}$.

Carignan, K.S., Taylor, L.A., Eakins, B.W., and Love, M., 2012, Digital elevation models of Gustavus and Hoonah, Alaska-Procedures, data sources, and analysis: NOAA Technical Memorandum.

Cossart, Etienne, Braucher, R., Fort, M., Bourlès, D.L., and Carcaillet, Julien, 2008, Slope instability in relation to glacial debuttressing in Alpine areas (upper Durance Catchment, southeastern France)—Evidence from field data and 10Be cosmic ray exposure ages: Geomorphology, v. 95 , no. $1-2$, p. 3-26.

DeMets, Charles, and Dixon, T.H., 1999, New kinematic model for the Pacific-North America motion from $3 \mathrm{Ma}$ to present, I, Evidence for steady motion and biases in the NUVEL-1A model: Geophysical Research Letters, v. 26, p. 921-924.

DeMets, Charles, Gordon, R.C., Argus, D.F., and Stein, Seth, 1990, Current plate motions: Geophysical Journal International, v. 101, no. 2, p. 425-478.

Doser, D.I., and Lomas, R., 2000, The transition from strikeslip to oblique subduction in southeastern Alaska from seismological studies: Tectonophysics, v. 316, p. 45-65.

Elliott, J.L., 2011, Active tectonics in southern Alaska and the role of the Yakutat block constrained by GPS measurements: Fairbanks, University of Alaska Ph.D. dissertation, $174 \mathrm{p}$.

Evans, S.G., and Clague, J.J., 1994, Recent climatic change and catastrophic geomorphic processes in mountain environments: Geomorphology, v. 10, p. 107-128.

Fine, I.V., Rabinovich, A.B., Kulikov, E.A., Thomson, R.E., and Bornhold, B.D., 1998, Numerical modeling of landslide-generated tsunamis with application to the Skagway Harbor tsunami of November 3, 1994, in Proceedings of International Conference on Tsunamis: Paris, p. 211-223.

Fine, I.V., Rabinovich, A.B., Bornhold, B.D., Thompson, R.E., and Kulikov, E.A., 2005, The Grand Banks landslide-generated tsunami of November 18, 1929Preliminary analysis and numerical modeling: Marine Geology, v. 215, no. 1-2, p. 45-57.

Fletcher, H.J., and Freymueller, J.T., 2003, New constraints on the motion of the Fairweather fault, Alaska, from GPS observations: Geophysical Research Letters, v. 30, p. 1,139. doi:10.1029/2002GL016476

Fournier, T.J., and Freymueller, J.T., 2007, Transition from locked to creeping subduction in the Shumagin region, Alaska: Geophysical Research Letters, v. 34, p. 6. doi:10.1029/2006GL029073

Freund, L.B., and Barnett, D.M., 1976, A two-dimensional analysis of surface deformation due to dip-slip faulting: Bulletin of the Seismological Society of America, v. 66, p. 667-675. 
Freymueller, J.T., Woodard, H., Cohen, S., Cross, R., Elliott, J., Larsen, C., Hreinsdottir, S., and Zweck, C., 2008, Active deformation processes in Alaska, based on 15 years of GPS measurements, in Freymueller, J.T., Haeussler, P.J., Wesson, R., and Ekström, G., eds., Active Tectonics and Seismic Potential of Alaska: Washington, D.C., American Geophysical Union Geophysical Monograph, v. 179, p. 1-42. doi:10.1029/179GM02

Fritz, H.M., 2002, Initial phase of landslide generated impulse waves: Zürich, Swiss Federal Institute of Technology (ETH), Ph.D. dissertation.

Fryer, G.J., and Watts, P., 2001, Motion of the Ugamak slide, probable source of the tsunami of 1 April 1946: Proceedings of the International Tsunami Symposium 2001, NOAA PMEL, p. 683-694.

Fujii, Yushiro, Satake, Kenji, Sakai, Shin'ichi, Shinohara, Masanao, and Kanazawa, Toshihiko, 2011, Tsunami source of the 2011 off the Pacific coast of Tohoku earthquake: Earth Planets Space, v. 63, p. 815-820.

Geist, E.L., Jakob, Matthias, Wieczorek, G.F., and Dartnell, Peter, 2003, Preliminary hydrodynamic analysis of landslide-generated waves in Tidal Inlet, Glacier Bay National Park, Alaska: U.S. Geological Survey Open-File Report 2003-411, 20 p.

Grilli, S.T., Harris, J.C., Tajalli Bakhsh, T., Masterlark, T.L., Kyriakopoulos, C., Kirby, J.T., and Shi, Fengyan, 2012, Numerical simulation of the 2011 Tohoku tsunami based on a new transient FEM co-seismic source-Comparison to far- and near-field observations: Pure and Applied Geophysics, v. 170, no. 6-8, p. 1,333-1,359, doi:10.1007/ s00024-012-0528-y

Gulick, S.P.S., Reece, R.S., Christeson, G.L., van Avendonk, H., Worthington, L.L., and Pavlis, T.L., 2013, Seismic images of the Transition Fault and the unstable Yakutat-Pacific-North American triple junction: Geology, v. 41, no. 5, p. 571-574, G33900.1. doi:10.1130/G33900.1

Hampton, M.A., Lemke, R.W., and Coulter, H.W., 1993, Submarine landslides that had a significant impact on man and his activities, Seward and Valdez, Alaska, in Schwab, W.C., Lee, H.J., and Twichell, D.C., eds., Submarine Landslides-Selected Studies in the U.S. Exclusive Economic Zone: U.S. Geological Survey Bulletin 2002, p. $123-134$.

Hance, J.J., 2003a, Development of a database and assessment of seafloor slope stability based on published literature: Austin, University of Texas at Austin, M.S. thesis.

Hance, J.J., 2003b, Submarine Slope Stability [based on M.S. Engineering Thesis, "Development of a database and assessment of seafloor slope stability based on published Literature" for University of Texas at Austin by J.J. Hance]: Project report prepared for the Minerals Management Service, MMS Project 421, Offshore Technology Research Center Library Number 8/03B121, 269 p.

Hayes, G.P., Wald, D.J., and Johnson, R.L., 2012, Slab1.0A three-dimensional model of global subduction zone geometries: Journal of Geophysical Research, v. 117, no. B1, 1 p. doi:10.1029/2011JB008524
Heinrich, Philippe, 1992, Nonlinear water waves generated by submarine and aerial landslides: Journal of Waterway, Port, Coastal, and Ocean Engineering,, v. 118, no. 3, p. 249-266.

Heinrich, Philippe, Mangeney, Anne, Guibourg, Sandrine, Rocher, Roger, Boudon, Georges, and Cheminee, JeanLouis, 1998, Simulation of water waves generated by a potential debris avalanche in Montserrat, Lesser Antilles: Geophysical Research Letters, v. 25, no. 19, p. 3,697-3,700.

Ito, Yoshihiro, Tsuji, Takeshi, Osada, Yukihito, Kido, Motoyuki, Inazu, Daisuke, Hayashi, Yutaka, Tsushima, Hiroaki, Hino, Ryota, and Fujimoto, Hiromi, 2011, Frontal wedge deformation near the source region of the 2011 Tohoku-Oki earthquake: Geophysical Research Letters, v. 38, no. 15, L00G05. doi:10.1029/2011GL048355

James, Thomas, Rogers, Garry, Cassidy, John, Dragert, Herb, Hyndman, Roy, Leonard, Lucinda, Nykolaishen, Lisa, Riedel, Michael, Schmidt, Michael, and Wang, Kelin, 2013, Field studies target 2012 Haida Gwaii earthquake: EOS Transactions, v. 94, no. 22, p. 197-198.

Jiang, Lin, and LeBlond, P.H., 1992, The coupling of a submarine slide and the surface waves which it generates: Journal of Geophysical Research, v. 97, no. C8, p. 12,731-12,744.

Jiang Lin, and LeBlond P.H., 1994, Three-dimensional modeling of tsunami generation due to a submarine mudslide: Journal of Physical Oceanography, v. 24, no. 3, p. 559-572.

Johnson, J.M., Tanioka, Yuichiro, Ruff, L.J., Satake, Kenji, Kanamori, Hiroo, and Sykes, L.R., 1994, The 1957 Great Aleutian Earthquake: Pure and Applied Geophysics, v. 142 , no. 1 , p. 3-28.

KellerLynn, Katie, 2009, Geologic resources inventory scoping summary - Glacier Bay National Park and Preserve, Alaska: Geologic Resources Division, National Park Service, U.S. Department of the Interior, 27 p., http:// www.nature.nps.gov/geology/inventory/publications/s_ summaries/glba_gri_scoping_summary_2009-1130.pdf.

Kulikov, E.A., Rabinovich, A.B., Fine, I.V., Bornhold, B.D., and Thomson, R.E., 1998, Tsunami generation by landslides at the Pacific coast of North America and the role of tides: Oceanology, v. 38, no. 3, p. 323-328.

Lacasse, Suzanne, Nadim, Farrokh, Vanneste, Maarten, L'Heureux, Jean-Sebastian, Forsberg, C.F., and Kvalstad, T.J., 2013, Case studies of offshore slope stability: Proceedings, Geo-Congress 2013, p. 2,369-2,408. doi:10.1061/9780784412787.228

Lahr, J.C., and Plafker, George, 1980, Holocene PacificNorth American plate interaction in southern AlaskaImplications for Yakataga seismic gap: Geology, v. 8, no. 10 , p. $483-486$.

Lander, J.F.; 1996, Tsunamis affecting Alaska, 1737-1996: Boulder, CO, National Geophysical Data Center (NGDC), NOAA, Key to Geophysical Research Documentation, v. 31,195 p.

Lastras, Galderic, Amblas, David, Calafat, A.M., Canals, Miquel, Frigola, Jaime, Hermanns, R.L., Lafuerza, 
Sara, Longva, Oddvar, Micallef, Aaron, Sepúlveda, S.A., Vargas, Gabriel, De Batist, Marc, Van Daele, Maarten, Azpiroz, María, Bascuñán, Ignacio, DuHart, Paul, Iglesias, Olaia, Kempf, Philipp, and Rayo, Xavier, 2013, Landslides cause tsunami waves-Insights from Aysén Fjord, Chile [abst.]: Eos Transactions, American Geophysical Union, v. 94, no. 34, p. 297-298. doi:10.1002/2013E0340002

Lay, Thorne, Ye, Lingling, Kanamori, Hiroo, Yamazaki, Yoshiki, Cheung, K.F., Kwong, Kevin, and Koper, K.D., 2013, The October 28, $2012 \mathrm{M}_{\mathrm{W}} 7.8$ Haida Gwaii underthrusting earthquake and tsunami-Slip partitioning along the Queen Charlotte fault transpressional plate boundary: Earth and Planetary Science Letters, v. 375, p. 57-70.

Lee, H.J., Schwab, W.C., and Booth J.S., 2002, Submarine landslides-An introduction, in Schwab, W.C., Lee, H.J., and Twichell, D.C., eds., Submarine LandslidesSelected Studies in the U.S. Exclusive Economic Zone: U.S. Geological Survey Bulletin 2002, p. 1-13.

Lee, H.J., Ryan, Holly, Kayen, R.E., Haeussler, P.J., Dartnell, Peter, and Hampton, M.A., 2006, Varieties of submarine failure morphologies of seismically-induced landslides in Alaskan fjords: Norwegian Journal of Geology (Norsk Geologisk Tidsskrift), v. 86, no. 3, p. 221-230.

Leonard, L.J., Rogers, G.C., and Mazzotti, Stephane, 2012, A preliminary tsunami hazard assessment of the Canadian coastline: Geological Survey of Canada, Open File 7201, 126 p. doi:10.4095/292067

Lim, E., Eakins, B.W., and Wigley, R., 2011, Coastal relief model of southern Alaska-Procedures, data sources and analysis: NOAA Technical Memorandum NESDIS NGDC-43, $22 \mathrm{p}$.

Love, M.R., Eakins, B.W., Taylor, L.A., Carignan, K.S., Friday, D., and Grothe, P.R., 2011, Digital elevation model of Elfin Cove, Alaska-Procedures, data sources and analysis: NOAA Technical Memorandum NESDIS NGDC-62, U.S. Dept. of Commerce, Boulder, CO, 36 p., http://www.ngdc.noaa.gov/dem/squareCellGrid/ download/253.

Lundgren, Paul, Saucier, Francois, Palmer, Randy, and Langon, Marc, 1995, Alaska crustal deformation-Finite element modeling constrained by geologic and very long baseline interferometry data: Journal of Geophysical Research, v. 100, no. B11, p. 22,033-22,045.

Masson, D.G., Harbitz, C.B., Wynn, R.B., Pedersen, G., and Løvholt, F., 2006, Submarine landslides_-Processes, triggers, and hazard prediction: Philosophical Transactions of the Royal Society A, v. 364, p. 2,009-2,039. doi:10.1098/ rsta.2006.1810

Mather, A.E., Hartley, A.J., and Griffiths, J.S., 2014, The giant coastal landslides of northern Chile-Tectonic and climate interactions on a classic convergent plate margin: Earth and Planetary Science Letters, v. 388, p. 249-256. doi:10.1016/j.epsl.2013.10.019

Mazzotti, Stéphane, Hyndman, R.D., Flück, Paul, Smith, A.J., and Schmidt, Michael, 2003, Distribution of the Pacific/North America motion in the Queen Charlotte
Islands - S. Alaska plate boundary zone: Geophysical Research Letters, v. 30, no. 14. doi:10.1029/2003GL017586

Mei, C.C., 1983, The Applied Dynamics of Ocean Surface Waves: John Wiley \& Sons, 760 p.

Miller, D.J., 1960, The Alaska Earthquake of July 10, 1958 Giant wave in Lituya Bay: Bulletin of the Seismological Society of America, v. 50, no. 2, p. 253-266.

Miller, J.J., and von Huene, R., 2013, A possible Tohokumagnitude tsunami along the Alaska Peninsula-The 1946 Scotch Cap Tsunami [abst.]: Abstracts of the 2013 AGU Fall Meeting. doi:10.1130/GES00715.1

Myers, E.P., and Baptista, A.M., 2001, Analysis of factors influencing simulations of the 1993 Hokkaido NanseiOki and 1964 Alaska tsunamis: Natural Hazards, v. 23, no. 1, p. 1-28.

Nadim Farrokh, 2012, Risk assessment for earthquakeinduced submarine slides, in Yamada, Y., Kawamura, K., Ikehara, K., Ogawa, Y., Urgeles, R., Mosher, D., Chaytor, J., and Strasser, M., eds., Submarine Mass Movements and Their Consequences, 5th International Symposium: Springer, Advances in Natural and Technological Hazards Research, v. 31, p. 15-27.

National Tsunami Hazard Mitigation Program (NTHMP), 2010, Guidelines and best practices for tsunami inundation modeling for evacuation planning: NTHMP Mapping \& Modeling Subcommittee, NOAA.

2012, Proceedings and Results of The 2011 NTHMP Model Benchmarking Workshop, Boulder: U.S. Department of Commerce/NOAA/NTHMP; (NOAA Special Report). 436 p. http://nthmp.tsunami.gov

National Research Council, Committee on the Alaska Earthquake of the Division of Earth Sciences, 1972, The Great Alaska Earthquake of 1964-Seismology and geodesy: Washington, D.C.: National Academy of Sciences, p. 98-99.

Nicolsky, D.J., Suleimani, E.N., and Hansen, R.A., 2011, Validation and verification of a numerical model for tsunami propagation and runup: Pure and Applied Geophysics, v. 168, p. 1,199-1,222, doi:10.1007/s00024-010-0231-9.

Nicolsky, D.J., 2012, Alaska tsunami model, in Proceedings and Results of the 2011 NTHMP Model Benchmarking Workshop: Boulder, CO, U.S. Department of Commerce/ NOAA/NTHMP, NOAA Special Report, p. 55-87. http:// nthmp.tsunami.gov

Nicolsky, D.J., Suleimani, E.N., and Koehler, R.D., 2014, Tsunami inundation maps of Cordova and Tatitlek, Alaska: Alaska Division of Geological \& Geophysical Surveys Report of Investigation 2014-1, 49 p. doi:10.14509/27241

Nishenko, S.P., and Jacob, K.H., 1990, Seismic potential of the Queen Charlotte-Alaska-Aleutian seismic zone: Journal of Geophysical Research, v. 95, no. B3, p. 2,511-2,532.

Okada, Yoshimitsu, 1985, Surface deformation due to shear and tensile faults in a half-space: Bulletin of the Seismological Society of America, v. 75, no. 4, p. 1,135-1,154.

Page, R.A., 1973, The Sitka, Alaska, earthquake of 1972: Earthquake Information Bulletin, v. 5, p. 4-9. 
Perez, O.J., and Jacob, K.H., 1980, Tectonic model and seismic potential of the eastern Gulf of Alaska and Yakataga seismic gap: Journal of Geophysical Research, v. 85, no. B12, p. 7,132-7,150.

Plafker, George, 1969, Tectonics of the March 27, 1964, Alaska earthquake: U.S. Geological Survey Professional Paper 543-I, p. I1-I74, 2 sheets, scale 1:500,000.

Priest, G.R., Goldfinger, Chris, Wang, Kelin, Witter, R.C., Zhang, Yinglong, and Baptista, A.M., 2009, Confidence levels for tsunami-inundation limits in northern Oregon inferred from a 10,000-year history of great earthquakes at the Cascadia subduction zone: Natural Hazards, v. 54, no. 1. doi:10.1007/s11069-009-9453-5

Rabinovich, A.B., Thomson, R.E., Bornhold, B.D., Fine, I.V., and Kulikov, E.A., 2003, Numerical modeling of tsunamis generated by hypothetical landslides in the Strait of Georgia, British Columbia: Pure and Applied Geophysics, v. 160, no. 7, p. 1,273-1,313.

Rohr, K.M.M., Scheidhauer, Maren, and Trehu, A.M., 2000, Transpression between two warm mafic platesThe Queen Charlotte fault revisited: Journal of Geophysical Research, v. 105, no. B4, p. 8,147-8,172. doi:10.1029/1999JB900403

Ross, S.L., Jones, L.M., Wilson, R.I., Bahng, B., Borrero, J.C., Brosnan, D.M., Bwarie, J.T., Geist, E.L., Johnson, L.A., Hansen, R.A., Kirby, S.H., Knight, E., Knight, W.R., Long, K., Lynett, P.J., Miller, K.M., Mortensen, C.E., Nicolsky, D.J., Oglesby, D.D., Perry, S.C., Porter, K.A., Real, C.R., Ryan, K.J., Suleimani, E.N., Thio, H.K., Titov, V.V., Wein, A.M., Whitmore, P., and Wood, N.J., 2012, USGS SAFRR tsunami scenario-Potential impacts to the U.S. west coast from a plausible M9 earthquake near the Alaska Peninsula [abst.]: American Geophysical Union Fall Meeting, San Francisco, CA, December 3-7, 2012.

Ryan, H.F.. Blakely, R.J., Kirby, S.H., Scholl, D.W., and von Huene, R., 2010, USGS multi-hazard demonstration project tsunami scenario-Selecting a scientifically defensible Aleutian megathrust earthquake source [abs.]: American Geophysical Union Fall Meeting, San Francisco, CA, December 3-7, 2012.

Satake, Kenji, Shimazaki, Kunihiko, Tsuji, Yoshinobu, and Ueda, Kazue, 1996, Time and size of a giant earthquake in Cascadia inferred from Japanese tsunami records of January 1700: Nature, v. 379, no. 6562, p. 246-249.

Satake, Kenji, Wang, Kelin, and Atwater, B.F., 2003, Fault slip and seismic moment of the 1700 Cascadia earthquake inferred from Japanese tsunami descriptions: Journal of Geophysical Research, v. 108, no. B11, p. 2,535-2,551. doi:10.1029/2003JB002521

Shao, G., Li, X., Ji, C., and Maeda, T., 2011, Focal mechanism and slip history of $2011 \mathrm{M}_{\mathrm{W}} 9.1$ off the Pacific coast of Tohoku earthquake, constrained with teleseismic body and surface waves: Earth Planets Space, v. 63, no. 7, p. 559-564. doi:10.5047/eps.2011.06.028

Smith, A.J., Hyndman, R.D., Cassidy, J.F., and Wang, Kelin, 2003, Structure, seismicity, and thermal regime of the Queen Charlotte transform margin: Journal of Geophysical Research, v. 108, no. B11, p. 2,539. doi:10.1029/2002JB002247

Suito, Hisashi, and Freymueller, J.T., 2009, A viscoelastic and afterslip postseismic deformation model for the 1964 Alaska earthquake: Journal of Geophysical Research, v. 114, no. B11, p. 404-426. doi:10.1029/2008JB005954

Suleimani, E.N., 2011, Numerical studies of tectonic and landslide-generated tsunamis caused by the 1964 Great Alaska Earthquake: Fairbanks, Alaska, University of Alaska Fairbanks, Ph.D. dissertation, 181 p.

Suleimani, E.N., Nicolsky, D.J., and Koehler, R.D., 2013, Tsunami inundation maps of Sitka, Alaska: Alaska Division of Geological \& Geophysical Surveys Report of Investigation 2013-3, 76 p., 1 sheet, scale 1:250,000. doi:10.14509/26671

Sykes, L.R., 1971, Aftershock zones of great earthquakes, seismicity gaps, and earthquake prediction for Alaska and the Aleutians: Journal of Geophysical Research, v. 75, p. 8,021-8,041.

Synolakis, C.E., and Bernard, E.N., 2006, Tsunami science before and beyond Boxing Day 2004, in Thompson, J.M.T., Heppert, H.E., and Sparks, R.S.J., eds., Extreme Natural Hazards: Philosophical Transactions of the Royal Society, Mathematical, Physical, and Engineering Sciences, v. 364, no. 1845, p. 2,231-2,265.

Synolakis, C.E., Bernard, E.N., Titov, V.V., Kânoğlu, U., and González, F.I., 2007, Standards, criteria, and procedures for NOAA evaluation of tsunami numerical models: Seattle, Washington, NOAA/Pacific Marine Environmental Laboratory, Technical Memorandum OAR PMEL-135, $55 \mathrm{p}$.

Tang, Liujuan, Titov, V.V., Bernard, E.N., Wei, Yong, Chamberlin, C.D., Newman, J.C., Mofjeld, H.O., Arcas, Diego, Eble, M.C., Moore, Christopher, Uslu, Burak, Pells, Clint, Spillane, Michael, Wright, Lindsey, and Gica, Edison, 2012, Direct energy estimation of the 2011 Japan tsunami using deep-ocean pressure measurements: Journal of Geophysical Research, v. 117, no. C8. doi:10.1029/2011JC007635

Thomson, R.E., Rabinovich, A.B., Kulikov, E.A., Fine, I.V., and Bornhold, B.D., 2001, On numerical simulation of the landslide-generated tsunami of November 3, 1994, in Skagway Harbor, Alaska, in Hebenstreit, G.T., ed., Tsunami research at the end of a critical decade: Kluwer, p. 243-282.

Titov, V.V., and Synolakis, C.E., 1995, Evolution and runup of breaking and nonbreaking waves using VTSC-2: Journal of Waterway, Port, Coastal, and Ocean Engineering, v. 121 , no. 6 , p. $308-316$.

1997, Extreme inundation flows during the Hokkaido-Nansei-Oki Tsunami. Geophysical Research Letters, v. 24, no. 11, p, 1,315-1,318.

Tocher, D., 1960, The Alaska earthquake of July 10, 1958 Movement on the Fairweather fault and field investigation of southern epicentral region: Bulletin of the Seismological Society of America, v. 50, no. 2, p. 267-292.

Visit Hoonah webpage, 2013, http://www.visithoonah.com/ history.html, last accessed 4/3/2014. 
Walder, J.S., Watts, P., and Waythomas, C.F., 2006, Case study-Mapping tsunami hazards associated with debris flow into a reservoir: Journal of Hydraulic Engineering, v. 132 , no. 1 , p. $1-11$.

Wang, Kelin, Wells, R.E., Mazzotti, Stéphane, Hyndman, R.D., and Sagiya, Takeshi, 2003, A revised dislocation model of interseismic deformation of the Cascadia subduction zone: Journal of Geophysical Research, v. 108, no. B1, p. 2,026-2,038. doi:10.1029/2001JB001227

Ward, S.N., and Asphaug, Erik, 2002, Impact tsunamiEltanin: Deep-Sea Research, Part II, Topical Studies in Oceanography, v. 49, no. 6, p. 1,073-1,079.

Watts, Philip, and Waythomas, C.F., 2003, Theoretical analysis of tsunami generation by pyroclastic flows: Journal of Geophysical Research, B, Solid Earth and Planets, v. 108, no. B12, 21 p.

Waythomas, C.F., Watts, Philip, and Walder, J.S., 2006, Numerical simulation of tsunami generation by cold volcanic mass flows at Augustine Volcano, Alaska: Natural Hazards and Earth System Science, v. 6, no. 5, p. 671-685.
Waythomas, C.F., Watts, Philip, Shi, Fengyan, and Kirby, J.T., 2009, Pacific basin tsunami hazards associated with mass flows in the Aleutian Arc of Alaska: Quaternary Science Reviews, v. 28, no. 11-12, p. 1,006-1,019, doi:10.1016/j. quascirev.2009.02.019.

Wesson, R.L., Boyd, O.S., Mueller, C.S., Bufe, C.G., Frankel, A.D., and Petersen, M.D., 2007, Revision of time-independent probabilistic seismic hazard maps for Alaska: U.S. Geological Survey Open-File Report 2007-1043, 33 p.

Wieczorek, G.F., Geist, E.L., Motyka, R.J., and Jakob, Matthias, 2007, Hazard assessment of the Tidal Inlet landslide and potential subsequent tsunami, Glacier Bay National Park, Alaska: Landslides, v. 4, no. 3, p. 205-215.

Witter, R.C., Zhang, Y., Wang, K., Priest, G.R., Goldfinger, C., Stimely, L.L., English, J.T., and Ferro, P.A., 2011, Simulating tsunami inundation at Bandon, Coos County, Oregon, using hypothetical Cascadia and Alaska earthquake scenarios: Oregon Department of Geology and Mineral Industries Special Paper 43, 57 p. 


\section{APPENDIX A ELFIN COVE}

Table A-1. The longitude and latitude locations of the time series points.

\begin{tabular}{|r|c|c|c|l|}
\hline & $\begin{array}{c}\text { Longitude } \\
\text { (deg. W) }\end{array}$ & $\begin{array}{c}\text { Latitude } \\
\text { (deg. N) }\end{array}$ & $\begin{array}{c}\text { Point location } \\
\text { (Water or Land) }\end{array}$ & \multicolumn{1}{|c|}{ Name of the time series point } \\
\hline 1 & -136.376944 & 58.221944 & W & North of Elfin Cove \\
\hline 2 & -136.393056 & 58.194722 & W & Granite Cove \\
\hline 3 & -136.355278 & 58.198889 & W & Elfin Cove \\
\hline 4 & -136.353333 & 58.195000 & W & Between the islands \\
\hline 5 & -136.346667 & 58.195000 & W & Tide gauge \\
\hline 6 & -136.346389 & 58.194444 & L & Barge landing \\
\hline 7 & -136.346667 & 58.193333 & L & General store \\
\hline 8 & -136.344444 & 58.193056 & W & Small boat harbor \\
\hline 9 & -136.345000 & 58.193889 & L & Post office \\
\hline 10 & -136.342778 & 58.192778 & L & Northern Star Lodge \\
\hline 11 & -136.341667 & 58.191389 & W & Shearwater Lodge \\
\hline 12 & -136.340000 & 58.190278 & W & Inner Harbor Lodge \\
\hline 13 & -136.343611 & 58.191389 & W & Oyster processing shed \\
\hline 14 & -136.339444 & 58.188333 & L & Icy Straits Lodge \\
\hline 15 & -136.349444 & 58.193611 & L & Tanaku Lodge \\
\hline
\end{tabular}

Table A-2. Calculated maximum sea level for all tectonic scenarios at locations listed in table A-1. The maximum water level above ground is provided for onshore locations (L), whereas the maximum water level above the preearthquake MHHW is provided for offshore locations (W).

\begin{tabular}{|c|c|c|c|c|c|c|c|c|c|c|}
\hline & \multirow{3}{*}{$\begin{array}{l}\text { Longitude } \\
\text { (deg. W) }\end{array}$} & \multirow{3}{*}{$\begin{array}{l}\text { Latitude } \\
\text { (deg. N) }\end{array}$} & \multirow{3}{*}{$\begin{array}{c}\text { Water } \\
\text { or } \\
\text { Land }\end{array}$} & \multicolumn{7}{|c|}{ Maximum Water Level Above Ground/Sea Level (m) } \\
\hline & & & & \multicolumn{7}{|c|}{ Scenarios } \\
\hline & & & & 1 & 2 & 3 & 4 & 5 & 6 & 7 \\
\hline 1 & -136.376944 & 58.221944 & W & 1.05 & 1.38 & 2.16 & 1.83 & 0.74 & 0.59 & 0.90 \\
\hline 2 & -136.393056 & 58.194722 & W & 1.03 & 1.52 & 2.59 & 2.35 & 0.75 & 0.74 & 1.02 \\
\hline 3 & -136.355278 & 58.198889 & W & 1.05 & 1.60 & 2.53 & 2.25 & 0.75 & 0.74 & 1.04 \\
\hline 4 & -136.353333 & 58.195000 & $W$ & 1.05 & 1.62 & 2.58 & 2.27 & 0.77 & 0.76 & 1.05 \\
\hline 5 & -136.346667 & 58.195000 & $W$ & 1.07 & 1.65 & 2.65 & 2.35 & 0.77 & 0.77 & 1.06 \\
\hline 6 & -136.346389 & 58.194444 & $L$ & 0.00 & 0.00 & 0.00 & 0.00 & 0.00 & 0.00 & 0.00 \\
\hline 7 & -136.346667 & 58.193333 & $L$ & 0.00 & 0.00 & 0.00 & 0.00 & 0.00 & 0.00 & 0.00 \\
\hline 8 & -136.344444 & 58.193056 & $w$ & 1.09 & 1.49 & 2.60 & 2.12 & 0.78 & 0.79 & 1.07 \\
\hline 9 & -136.345000 & 58.193889 & $\mathrm{~L}$ & 1.11 & 1.51 & 2.61 & 2.13 & 0.78 & 0.79 & 1.07 \\
\hline 10 & -136.342778 & 58.192778 & $L$ & 0.00 & 0.00 & 0.00 & 0.00 & 0.00 & 0.00 & 0.00 \\
\hline 11 & -136.341667 & 58.191389 & $\mathrm{~W}$ & 1.11 & 1.52 & 2.68 & 2.15 & 0.80 & 0.81 & 1.09 \\
\hline 12 & -136.340000 & 58.190278 & $\mathrm{~W}$ & 1.12 & 1.53 & 2.71 & 2.17 & 0.82 & 0.82 & 1.11 \\
\hline 13 & -136.343611 & 58.191389 & W & 1.11 & 1.51 & 2.67 & 2.14 & 0.80 & 0.81 & 1.09 \\
\hline 14 & -136.339444 & 58.188333 & $L$ & 0.00 & 0.00 & 0.00 & 0.00 & 0.00 & 0.00 & 0.00 \\
\hline 15 & -136.349444 & 58.193611 & $L$ & 0.00 & 0.00 & 0.00 & 0.00 & 0.00 & 0.00 & 0.00 \\
\hline
\end{tabular}


Table A-3. Calculated maximum water current velocities for all tectonic scenarios at locations listed in table A-1. The onshore locations are indicated by L, whereas the offshore locations are marked by W.

\begin{tabular}{|c|c|c|c|c|c|c|c|c|c|c|}
\hline & \multirow{3}{*}{$\begin{array}{l}\text { Longitude } \\
\text { (deg. W) }\end{array}$} & \multirow{3}{*}{$\begin{array}{l}\text { Latitude } \\
\text { (deg. N) }\end{array}$} & \multirow{3}{*}{$\begin{array}{c}\text { Water } \\
\text { or } \\
\text { Land }\end{array}$} & \multicolumn{7}{|c|}{ Maximum Water Velocity (m/second) } \\
\hline & & & & \multicolumn{7}{|c|}{ Scenarios } \\
\hline & & & & 1 & 2 & 3 & 4 & 5 & 6 & 7 \\
\hline 1 & -136.376944 & 58.221944 & $\mathrm{~W}$ & 0.29 & 0.45 & 0.81 & 0.65 & 0.29 & 0.23 & 0.59 \\
\hline 2 & -136.393056 & 58.194722 & W & 0.07 & 0.12 & 0.20 & 0.16 & 0.06 & 0.05 & 0.09 \\
\hline 3 & -136.355278 & 58.198889 & W & 0.28 & 0.39 & 0.62 & 0.53 & 0.23 & 0.21 & 0.38 \\
\hline 4 & -136.353333 & 58.195000 & W & 0.34 & 0.56 & 0.86 & 0.83 & 0.27 & 0.21 & 0.41 \\
\hline 5 & -136.346667 & 58.195000 & W & 0.23 & 0.34 & 1.19 & 0.99 & 0.12 & 0.13 & 0.85 \\
\hline 6 & -136.346389 & 58.194444 & $\mathrm{~L}$ & 0.00 & 0.00 & 0.00 & 0.00 & 0.00 & 0.00 & 0.00 \\
\hline 7 & -136.346667 & 58.193333 & $\mathrm{~L}$ & 0.00 & 0.00 & 0.00 & 0.00 & 0.00 & 0.00 & 0.00 \\
\hline 8 & -136.344444 & 58.193056 & W & 0.18 & 0.22 & 0.37 & 0.32 & 0.10 & 0.09 & 0.13 \\
\hline 9 & -136.345000 & 58.193889 & $\mathrm{~L}$ & 0.18 & 0.21 & 0.26 & 0.24 & 0.12 & 0.11 & 0.14 \\
\hline 10 & -136.342778 & 58.192778 & $\mathrm{~L}$ & 0.00 & 0.00 & 0.00 & 0.00 & 0.00 & 0.00 & 0.00 \\
\hline 11 & -136.341667 & 58.191389 & W & 0.09 & 0.10 & 0.13 & 0.13 & 0.04 & 0.04 & 0.06 \\
\hline 12 & -136.340000 & 58.190278 & W & 0.12 & 0.13 & 0.16 & 0.15 & 0.07 & 0.06 & 0.09 \\
\hline 13 & -136.343611 & 58.191389 & W & 0.31 & 0.43 & 0.51 & 0.55 & 0.20 & 0.18 & 0.27 \\
\hline 14 & -136.339444 & 58.188333 & L & 0.00 & 0.00 & 0.00 & 0.00 & 0.00 & 0.00 & 0.00 \\
\hline 15 & -136.349444 & 58.193611 & $\mathrm{~L}$ & 0.00 & 0.00 & 0.00 & 0.00 & 0.00 & 0.00 & 0.00 \\
\hline
\end{tabular}




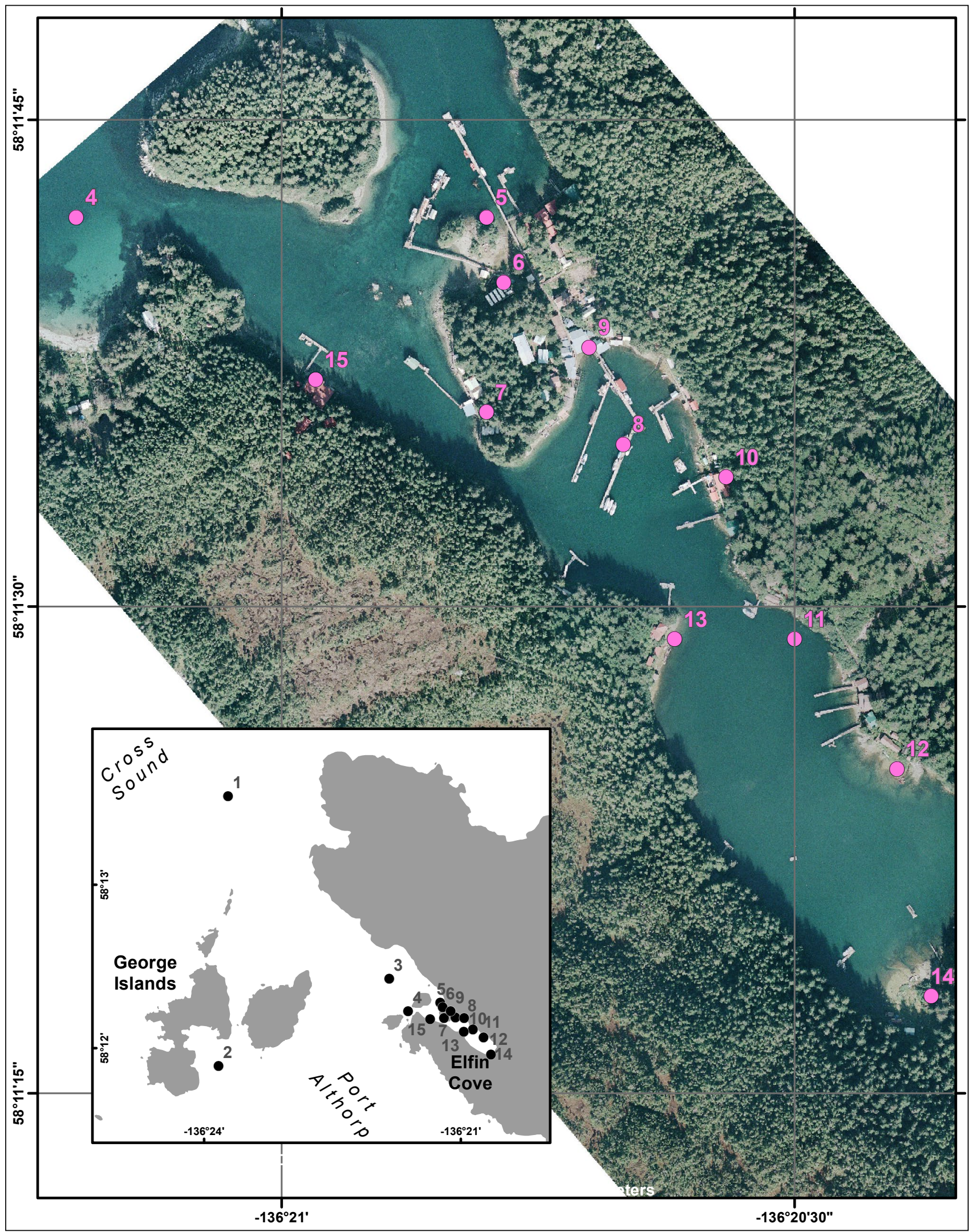

Figure A-1. Locations of time-series points in the Elfin Cove high-resolution grid. 


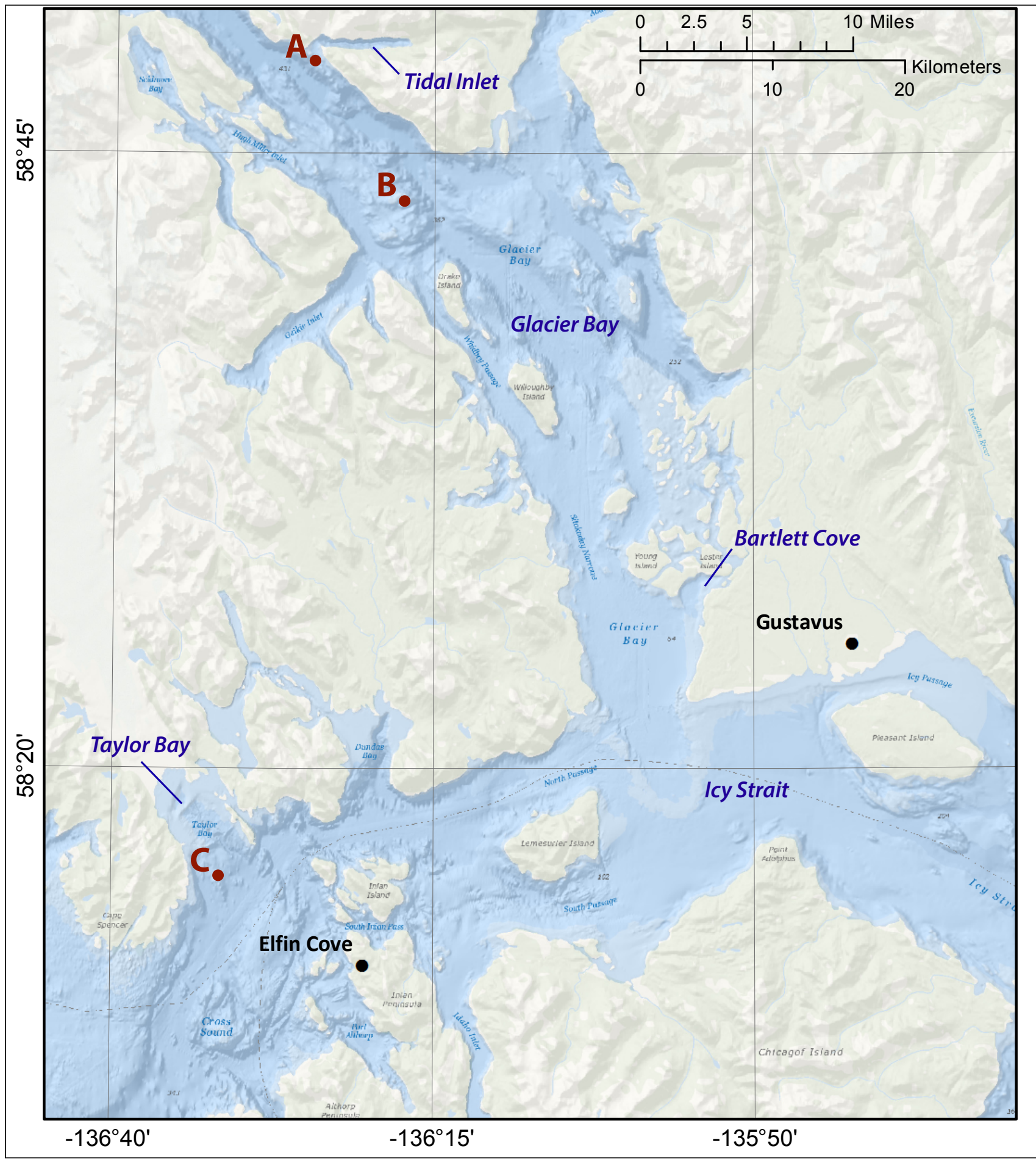

Figure A-2. Locations of time-series points in the grid that covers Glacier Bay and Icy Strait. 


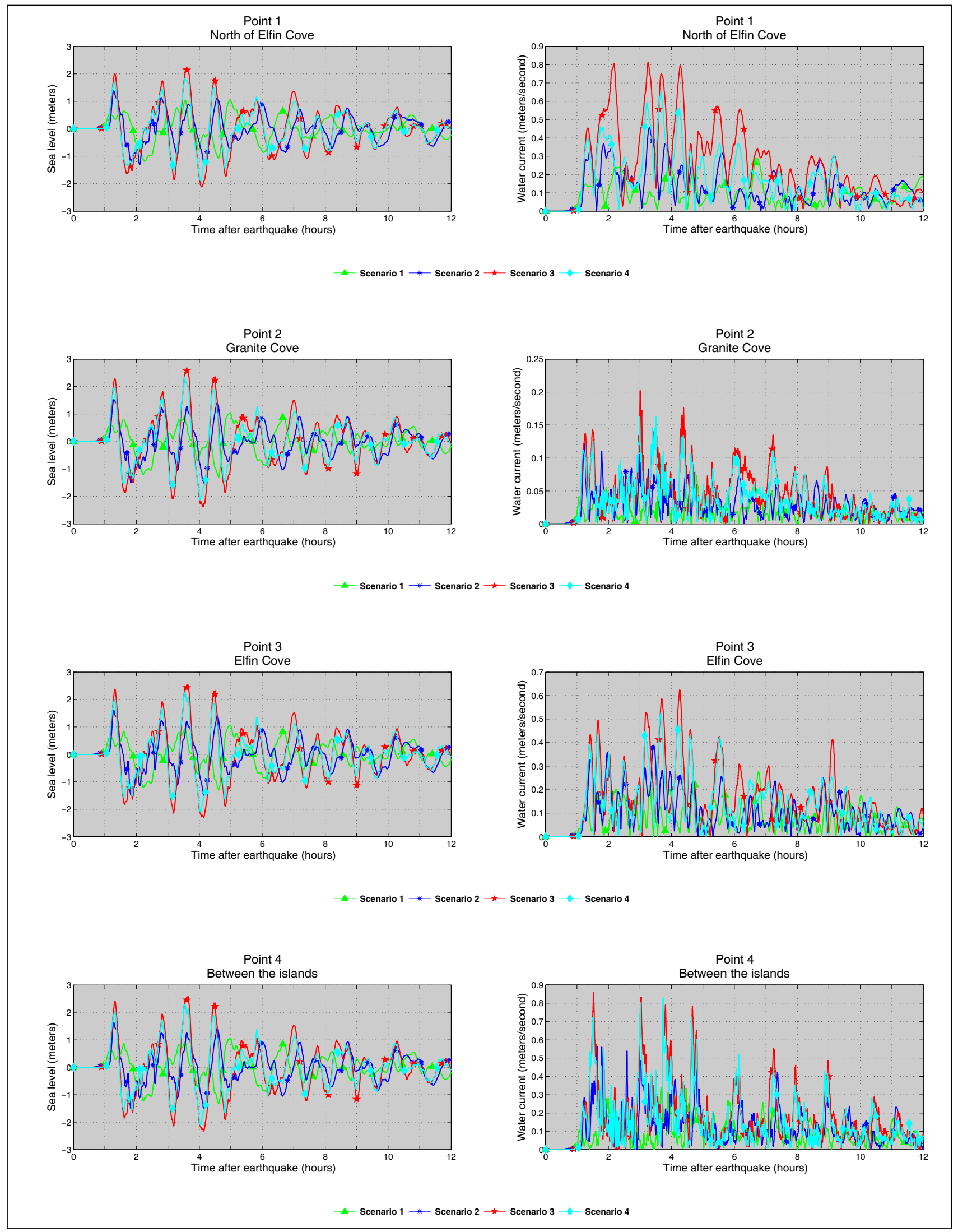

Figure A-3. Time series of the water level and velocity at Elfin Cove for scenarios 1-4 at the locations shown in figure A-1. 


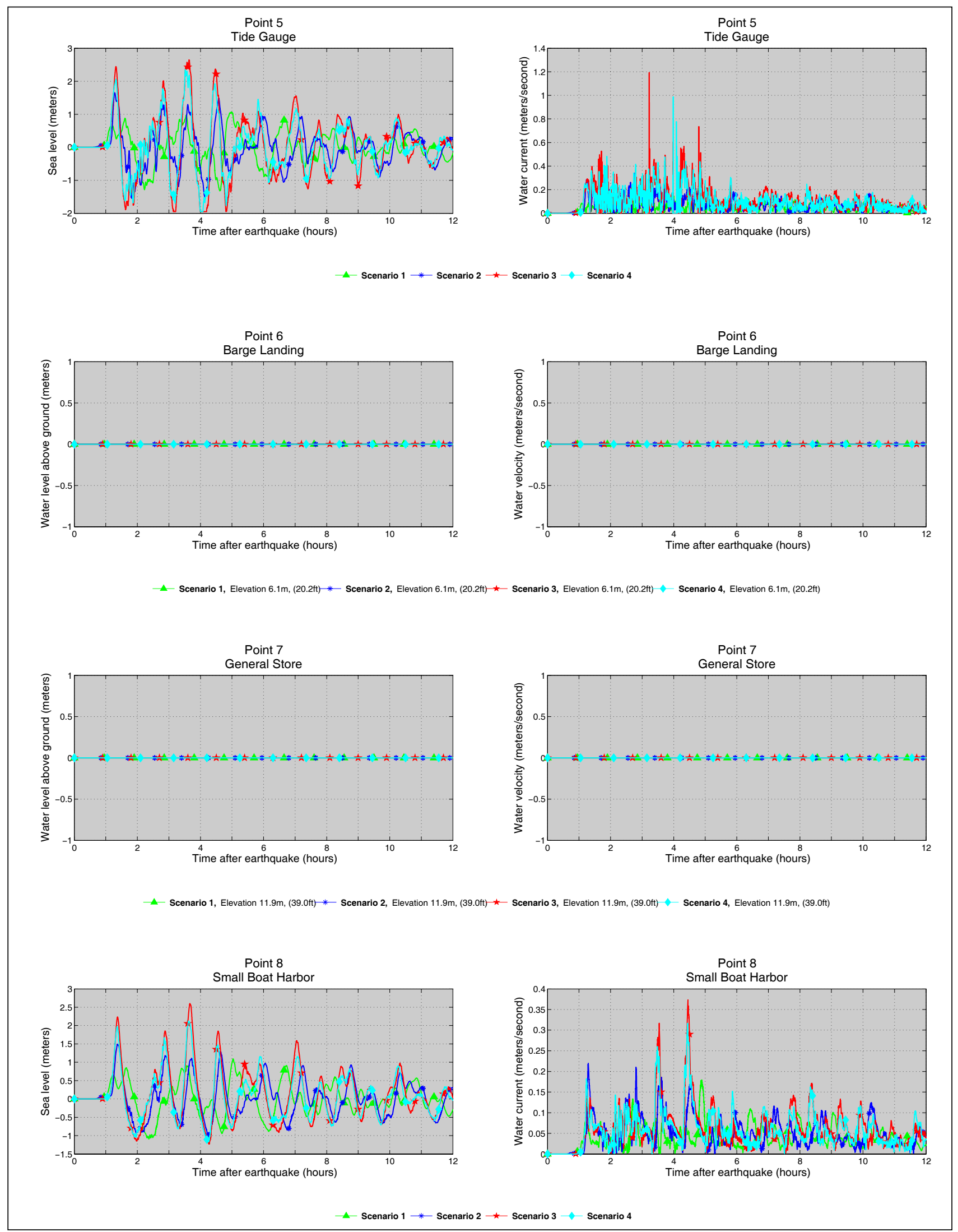

Figure A-3, continued. Time series of the water level and velocity at Elfin Cove for scenarios 1-4 at the locations shown in figure $A-1$. 


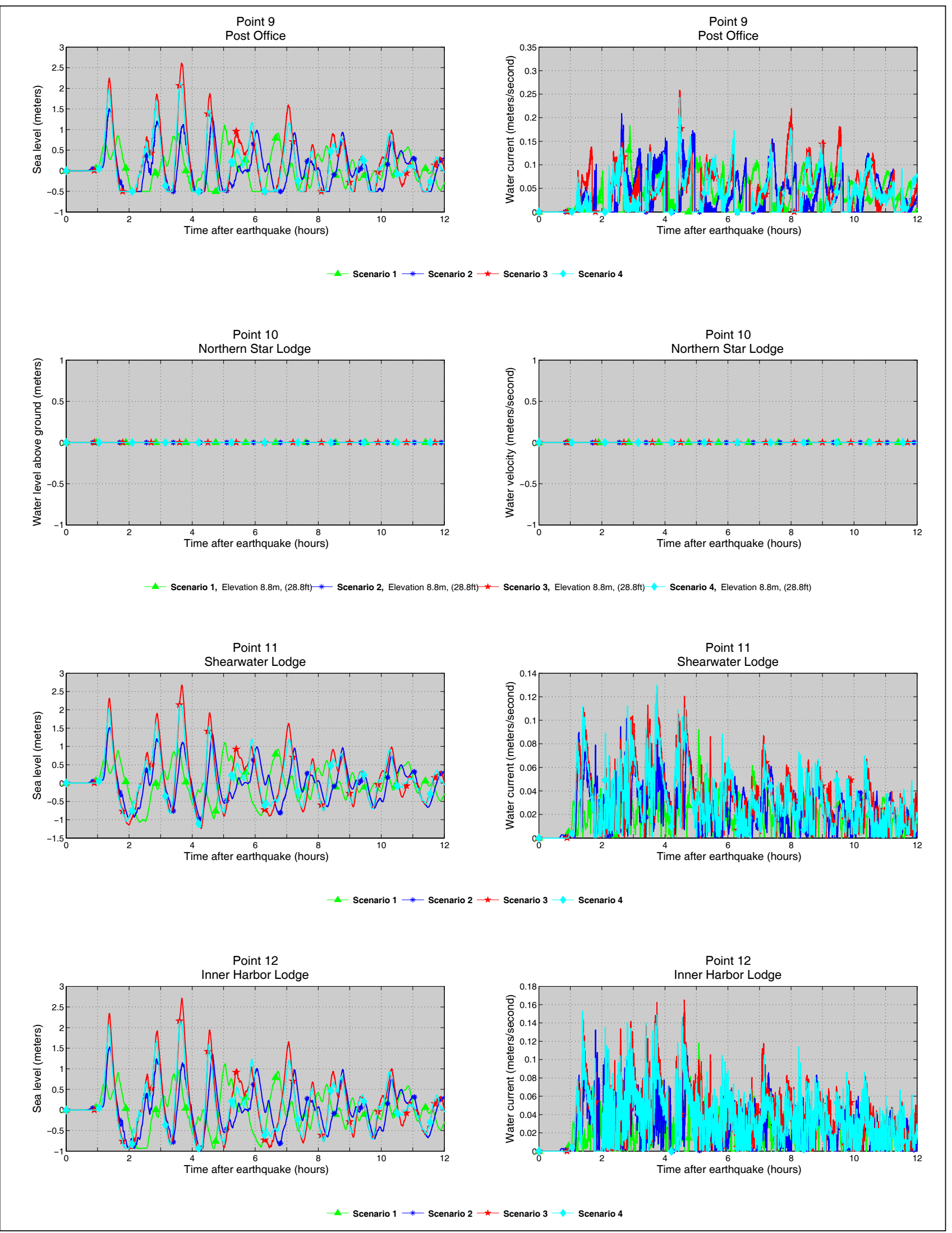

Figure A-3, continued. Time series of the water level and velocity at Elfin Cove for scenarios $1-4$ at the locations shown in figure $A-1$. 


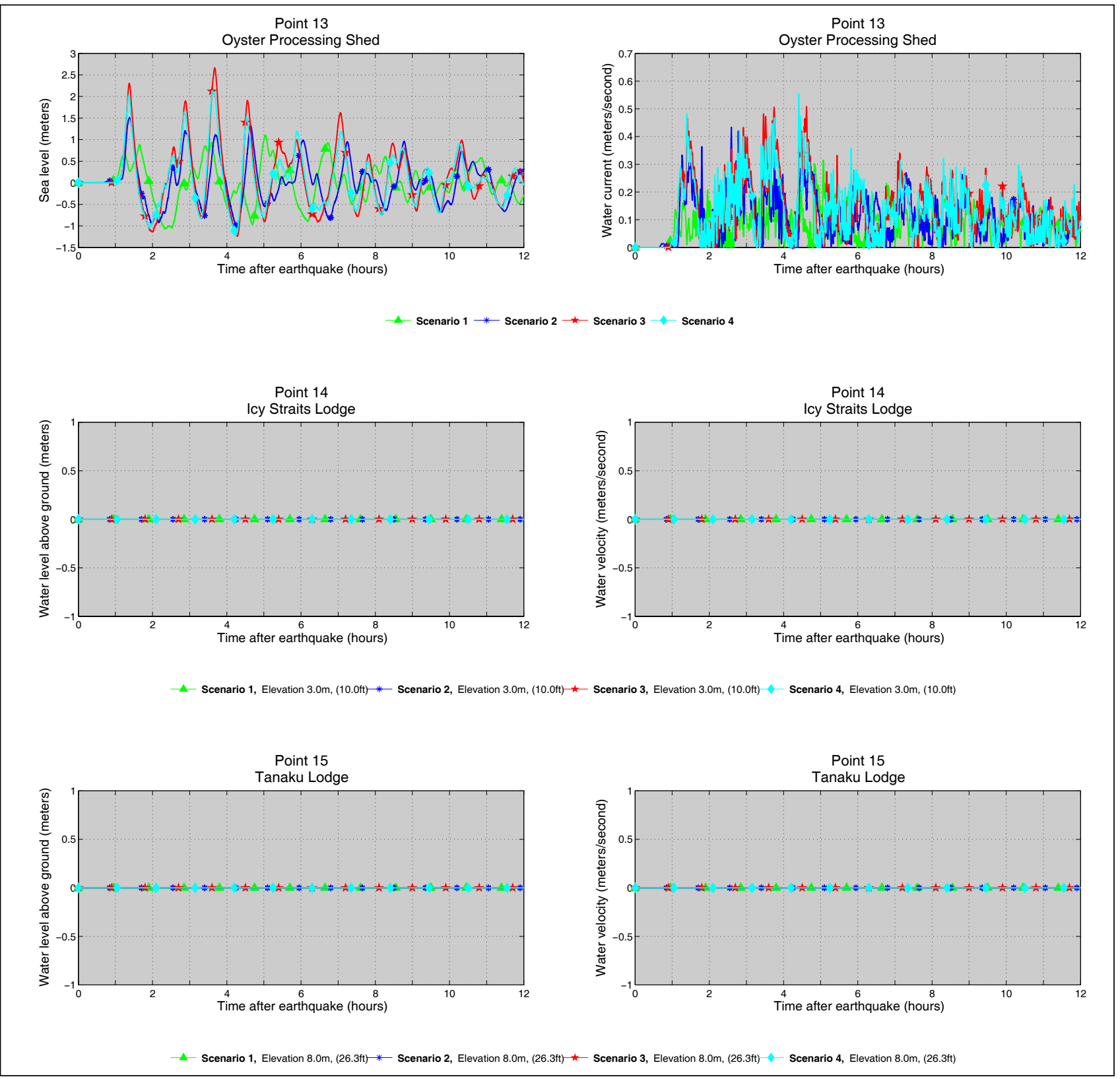

Figure A-3, continued. Time series of the water level and velocity at Elfin Cove for scenarios $1-4$ at the locations shown in figure $A-1$. 


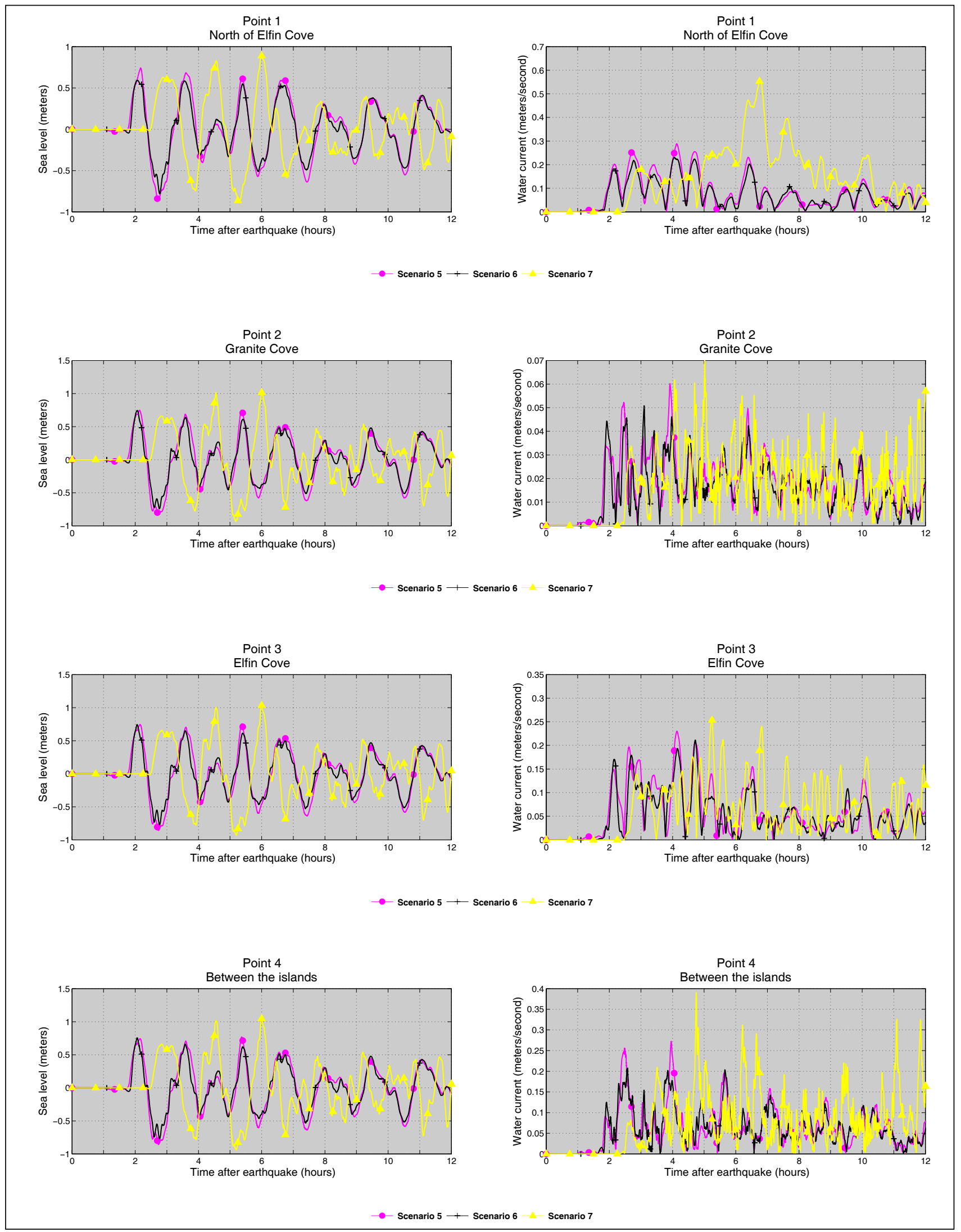

Figure A-4. Time series of the water level and velocity at Elfin Cove for scenarios 5-7 at the locations shown in figure A-1. 


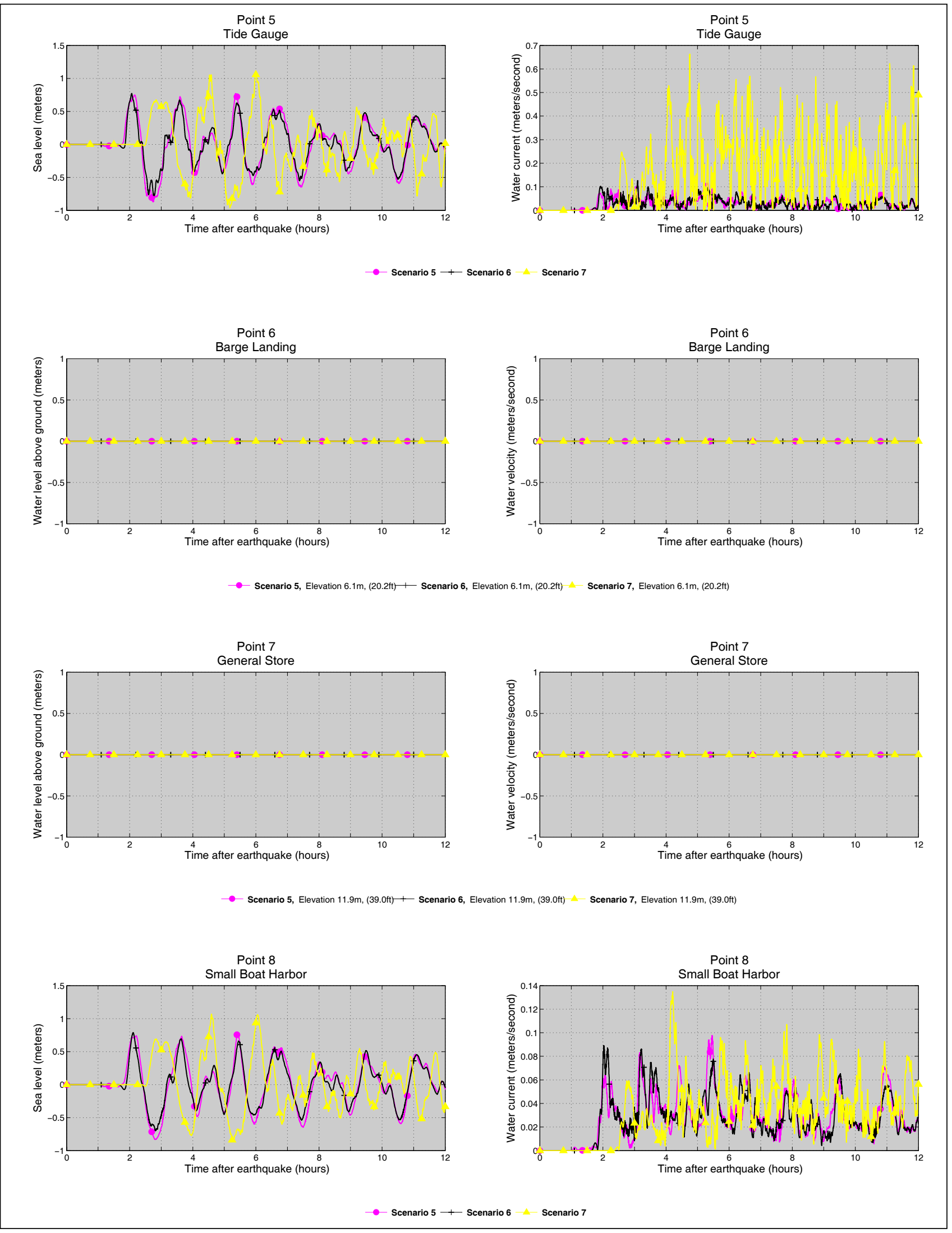

Figure A-4 (continued). Time series of the water level and velocity at Elfin Cove for scenarios 5-7 at the locations shown in figure A-1. 


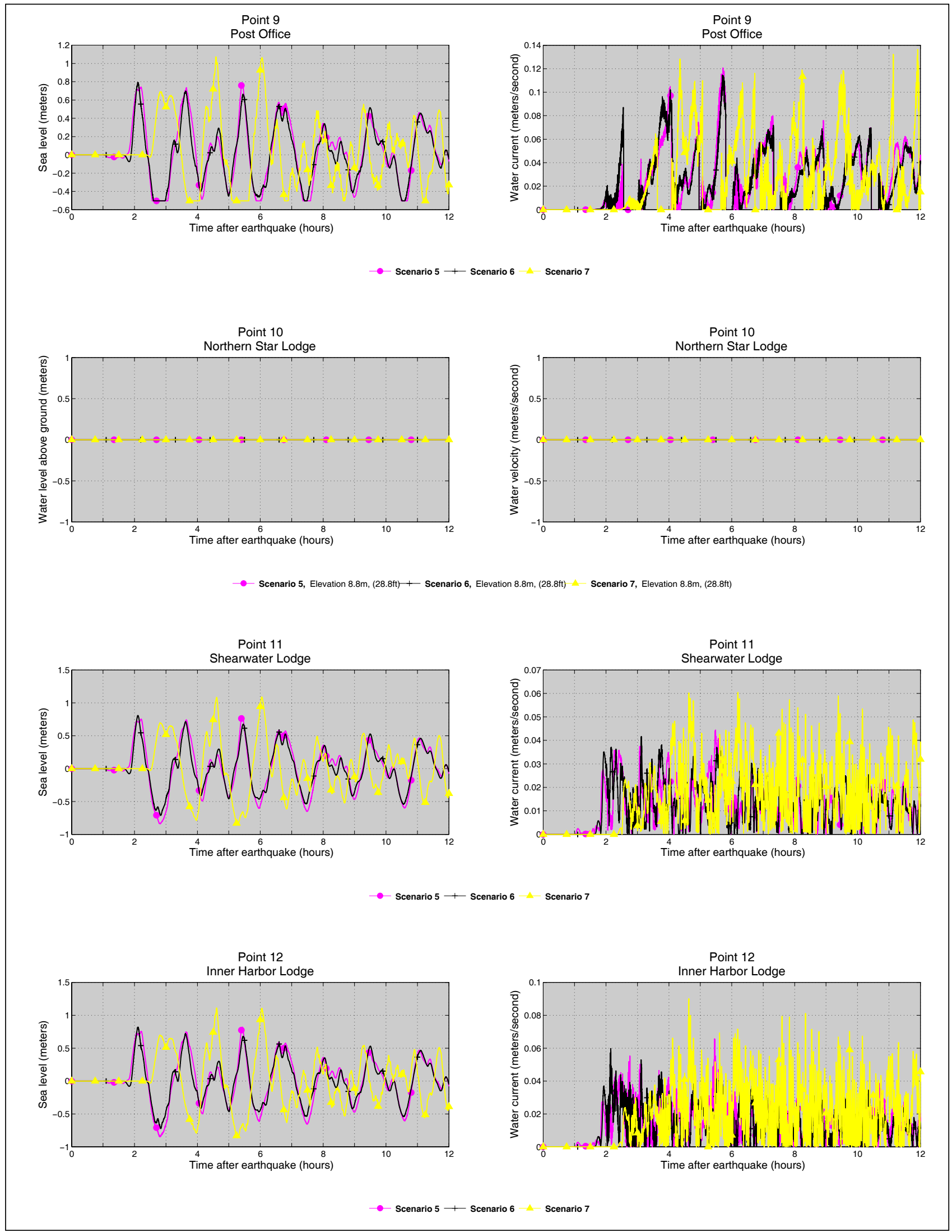

Figure A-4 (continued). Time series of the water level and velocity at Elfin Cove for scenarios 5-7 at the locations shown in figure $A-1$. 


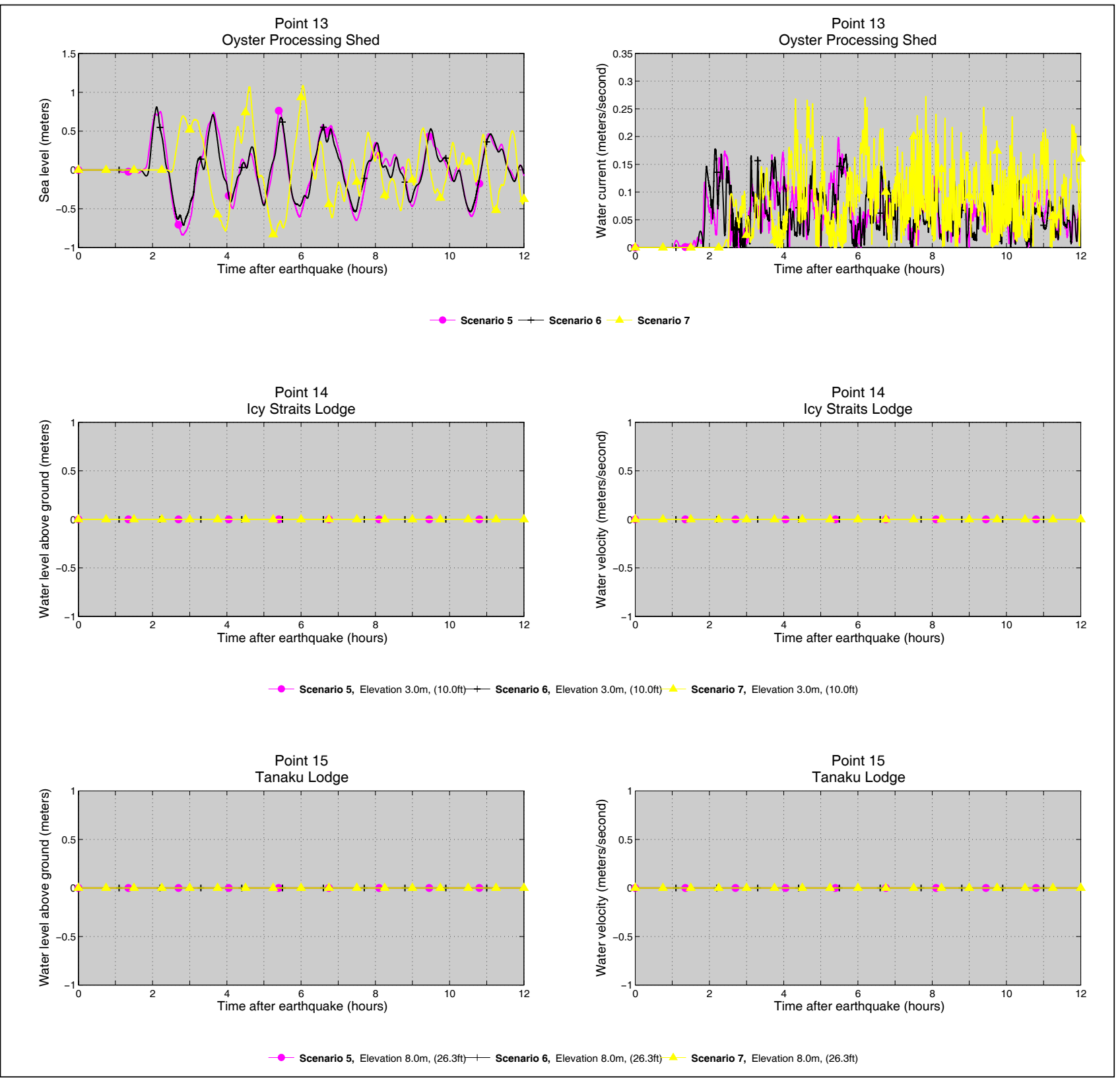

Figure A-4 (continued). Time series of the water level and velocity at Elfin Cove for scenarios 5-7 at the locations shown in figure $A-1$. 

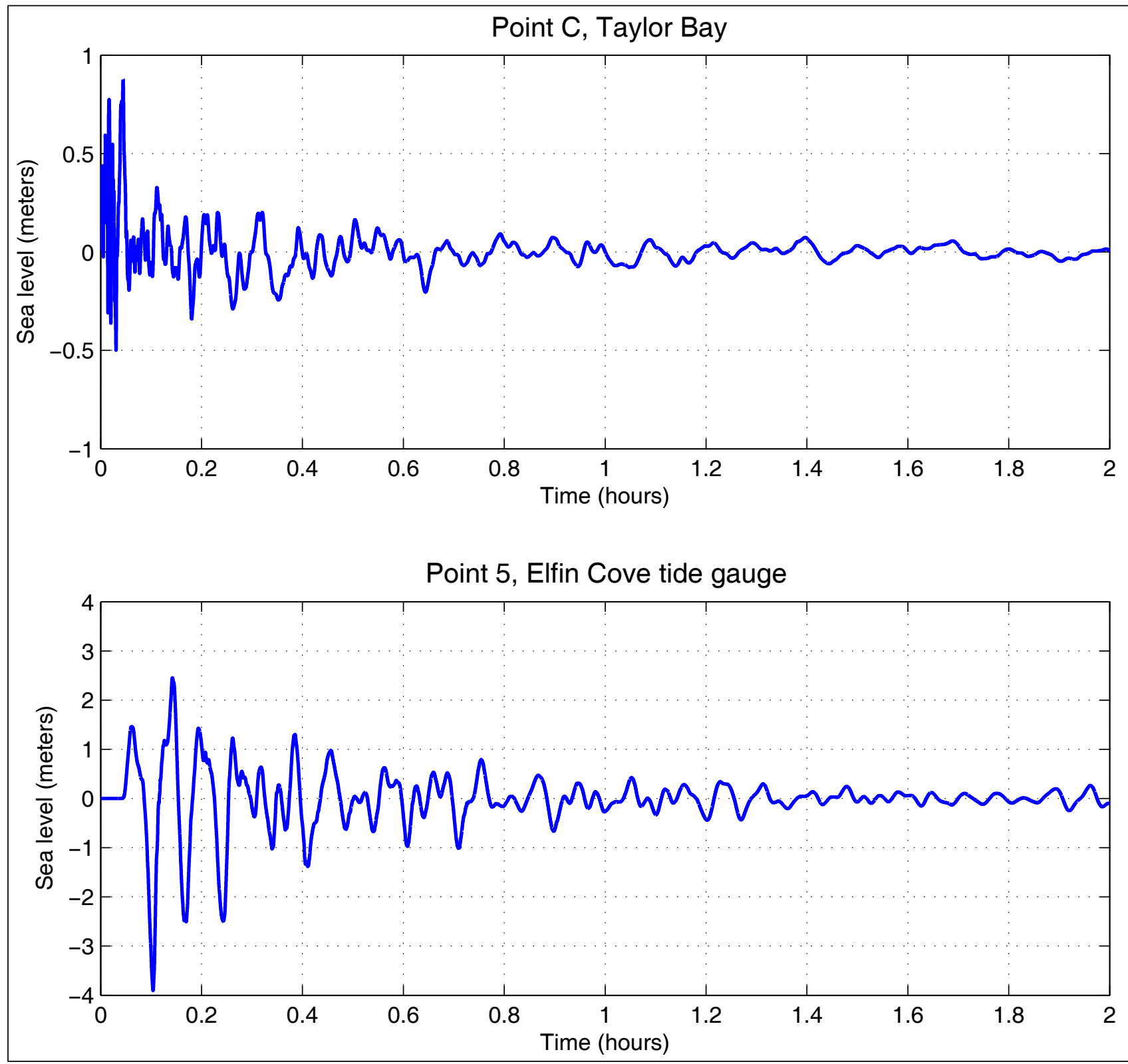

Figure A-5. Time series of the water level and velocity for scenario 8 (underwater slide in Taylor Bay) at the locations shown in figures $A-1$ and $A-2$. 

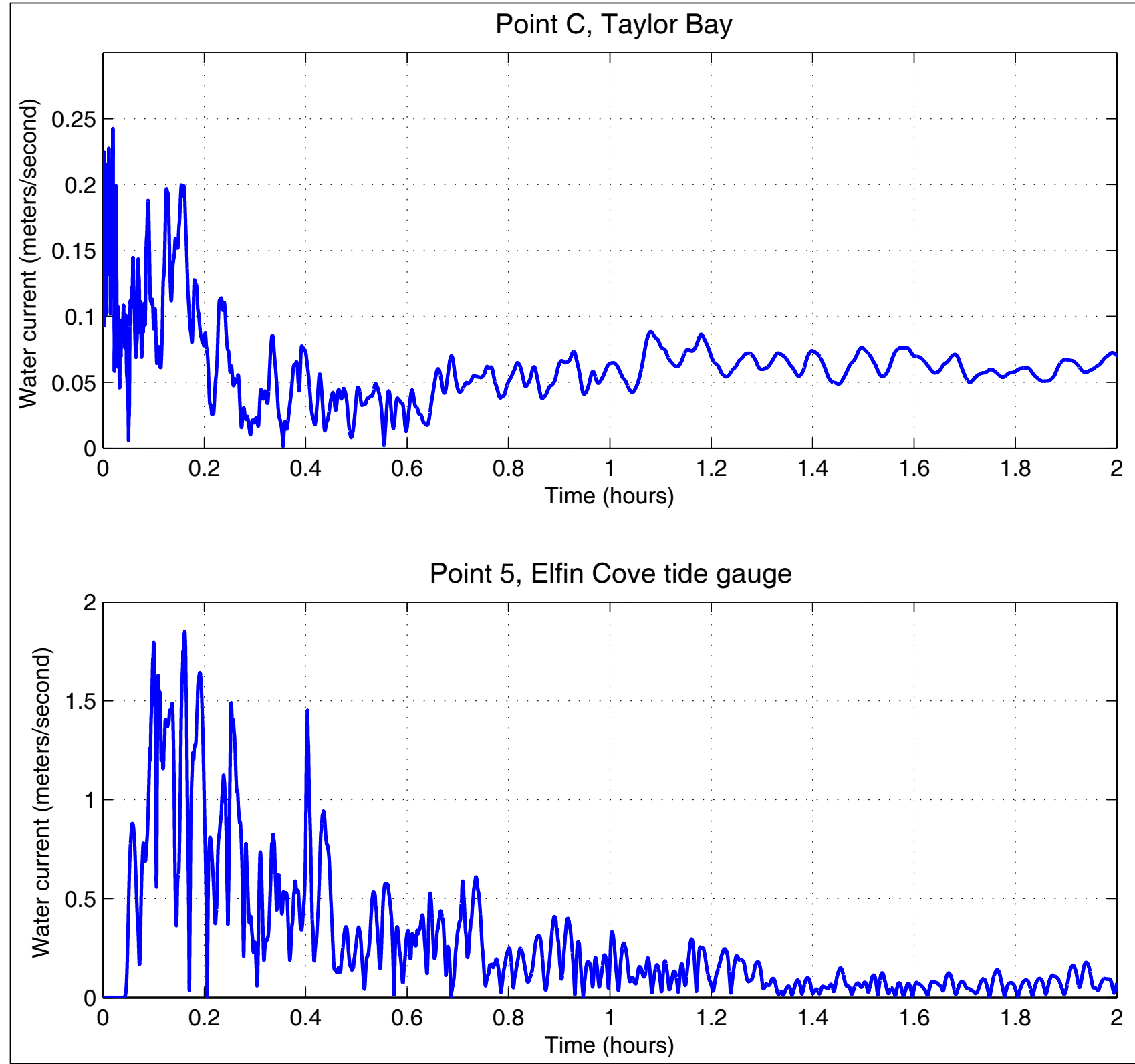

Figure A-5 (continued). Time series of the water level and velocity for scenario 8 (underwater slide in Taylor Bay) at the locations shown in figures $A-1$ and $A-2$. 


\section{APPENDIX B GUSTAVUS}

Table B-1. The longitude and latitude locations of the time series points.

\begin{tabular}{|r|c|c|c|l|}
\hline & $\begin{array}{c}\text { Longitude } \\
\text { (deg. W) }\end{array}$ & $\begin{array}{c}\text { Latitude } \\
\text { (deg. N) }\end{array}$ & $\begin{array}{c}\text { Point location } \\
\text { (Water or Land) }\end{array}$ & \multicolumn{1}{|c|}{ Name of the time series point } \\
\hline 1 & -135.699444 & 58.385000 & W & Icy Passage \\
\hline 2 & -135.892778 & 58.460000 & W & Bartlett Cove \\
\hline 3 & -135.887778 & 58.454722 & W & Docks \\
\hline 4 & -135.882778 & 58.454722 & L & Glacier Bay Lodge \\
\hline 5 & -135.869722 & 58.456389 & W & Lagoon dock \\
\hline 6 & -135.729167 & 58.389167 & W & Marine facility \\
\hline 7 & -135.728611 & 58.393333 & L & Tank farm \\
\hline 8 & -135.732778 & 58.403056 & W & Salmon River \\
\hline 9 & -135.730278 & 58.404167 & L & Harbor Road \\
\hline 10 & -135.693056 & 58.419722 & L & Airport, southeast \\
\hline 11 & -135.723333 & 58.416944 & L & Airport, southwest \\
\hline 12 & -135.719167 & 58.433611 & L & Airport, northwest \\
\hline 13 & -135.716944 & 58.400833 & L & Benjamin Drive \\
\hline 14 & -135.742500 & 58.405833 & L & Seaview Drive \\
\hline 15 & -135.747778 & 58.405833 & L & Alder Street \\
\hline
\end{tabular}

Table B-2. Calculated maximum sea level for all tectonic scenarios at locations listed in table B-1. The maximum water level above ground is provided for onshore locations (L), whereas the maximum water level above the preearthquake MHHW is provided for offshore locations (W).

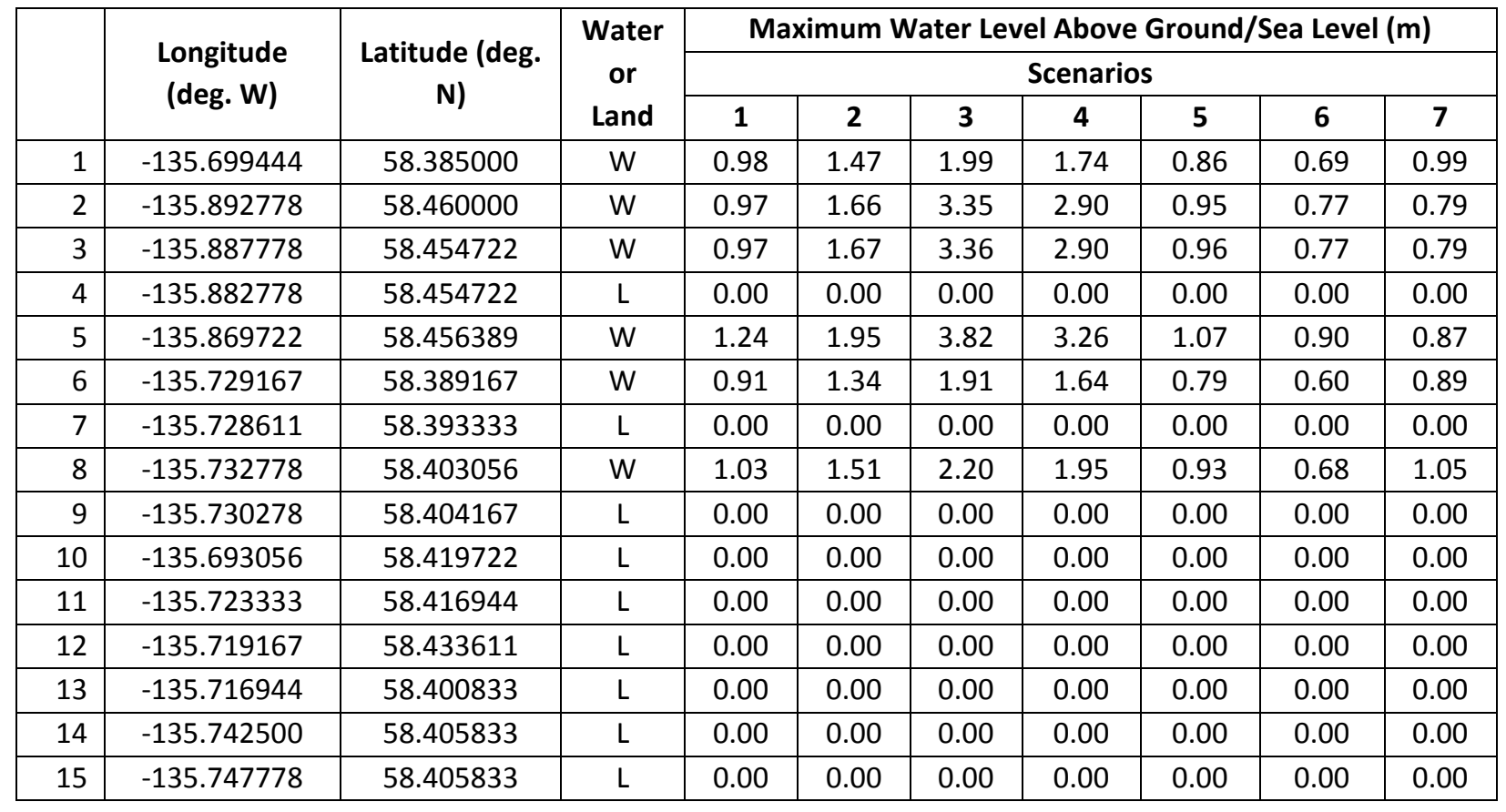


Table B-3. Calculated maximum water current velocities for all tectonic scenarios at locations listed in table B-1. The onshore locations are indicated by L, whereas the offshore locations are marked by W.

\begin{tabular}{|c|c|c|c|c|c|c|c|c|c|c|}
\hline & \multirow{3}{*}{$\begin{array}{l}\text { Longitude } \\
\text { (deg. W) }\end{array}$} & \multirow{3}{*}{$\begin{array}{l}\text { Latitude (deg. } \\
\text { N) }\end{array}$} & \multirow{3}{*}{$\begin{array}{c}\text { Water } \\
\text { or } \\
\text { Land }\end{array}$} & \multicolumn{7}{|c|}{ Maximum Water Velocity (m/second) } \\
\hline & & & & \multicolumn{7}{|c|}{ Scenarios } \\
\hline & & & & 1 & 2 & 3 & 4 & 5 & 6 & 7 \\
\hline 1 & -135.699444 & 58.385000 & W & 1.17 & 2.05 & 3.47 & 2.96 & 1.27 & 1.11 & 1.06 \\
\hline 2 & -135.892778 & 58.460000 & W & 0.18 & 0.28 & 0.34 & 0.27 & 0.08 & 0.09 & 0.09 \\
\hline 3 & -135.887778 & 58.454722 & W & 0.21 & 0.34 & 0.39 & 0.32 & 0.10 & 0.11 & 0.11 \\
\hline 4 & -135.882778 & 58.454722 & $\mathrm{~L}$ & 0.00 & 0.00 & 0.00 & 0.00 & 0.00 & 0.00 & 0.00 \\
\hline 5 & -135.869722 & 58.456389 & $W$ & 0.34 & 0.49 & 0.61 & 0.39 & 0.19 & 0.20 & 0.22 \\
\hline 6 & -135.729167 & 58.389167 & $\mathrm{~W}$ & 0.71 & 1.29 & 2.00 & 1.75 & 0.82 & 0.79 & 0.62 \\
\hline 7 & -135.728611 & 58.393333 & $\mathrm{~L}$ & 0.00 & 0.00 & 0.00 & 0.00 & 0.00 & 0.00 & 0.00 \\
\hline 8 & -135.732778 & 58.403056 & W & 1.31 & 2.06 & 1.93 & 1.78 & 1.05 & 0.90 & 1.18 \\
\hline 9 & -135.730278 & 58.404167 & $\mathrm{~L}$ & 0.00 & 0.00 & 0.00 & 0.00 & 0.00 & 0.00 & 0.00 \\
\hline 10 & -135.693056 & 58.419722 & $\mathrm{~L}$ & 0.00 & 0.00 & 0.00 & 0.00 & 0.00 & 0.00 & 0.00 \\
\hline 11 & -135.723333 & 58.416944 & $\mathrm{~L}$ & 0.00 & 0.00 & 0.00 & 0.00 & 0.00 & 0.00 & 0.00 \\
\hline 12 & -135.719167 & 58.433611 & L & 0.00 & 0.00 & 0.00 & 0.00 & 0.00 & 0.00 & 0.00 \\
\hline 13 & -135.716944 & 58.400833 & $\mathrm{~L}$ & 0.00 & 0.00 & 0.00 & 0.00 & 0.00 & 0.00 & 0.00 \\
\hline 14 & -135.742500 & 58.405833 & $\mathrm{~L}$ & 0.00 & 0.00 & 0.00 & 0.00 & 0.00 & 0.00 & 0.00 \\
\hline 15 & -135.747778 & 58.405833 & $\mathrm{~L}$ & 0.00 & 0.00 & 0.00 & 0.00 & 0.00 & 0.00 & 0.00 \\
\hline
\end{tabular}




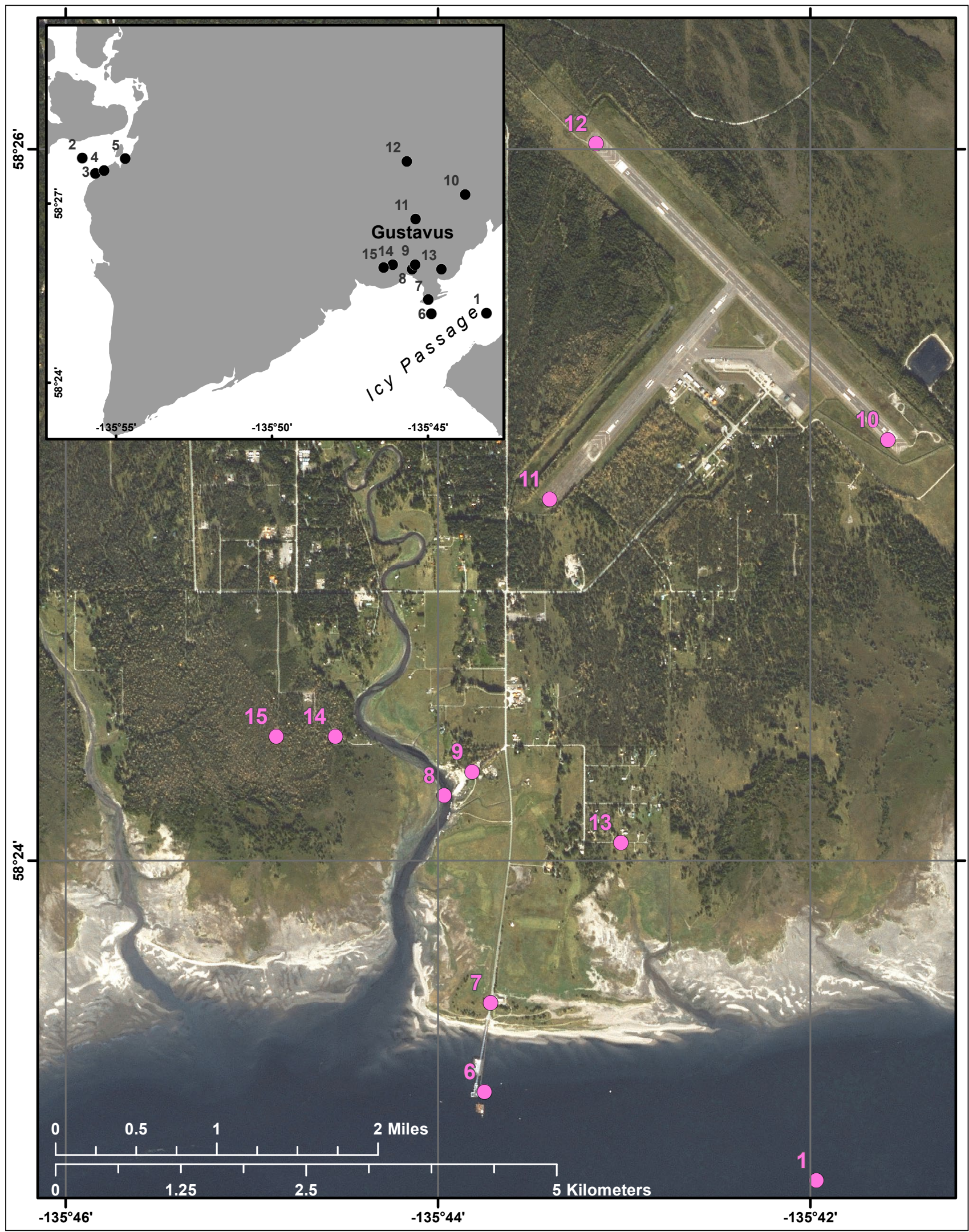

Figure B-1. Locations of time-series points in the Gustavus high-resolution grid. 


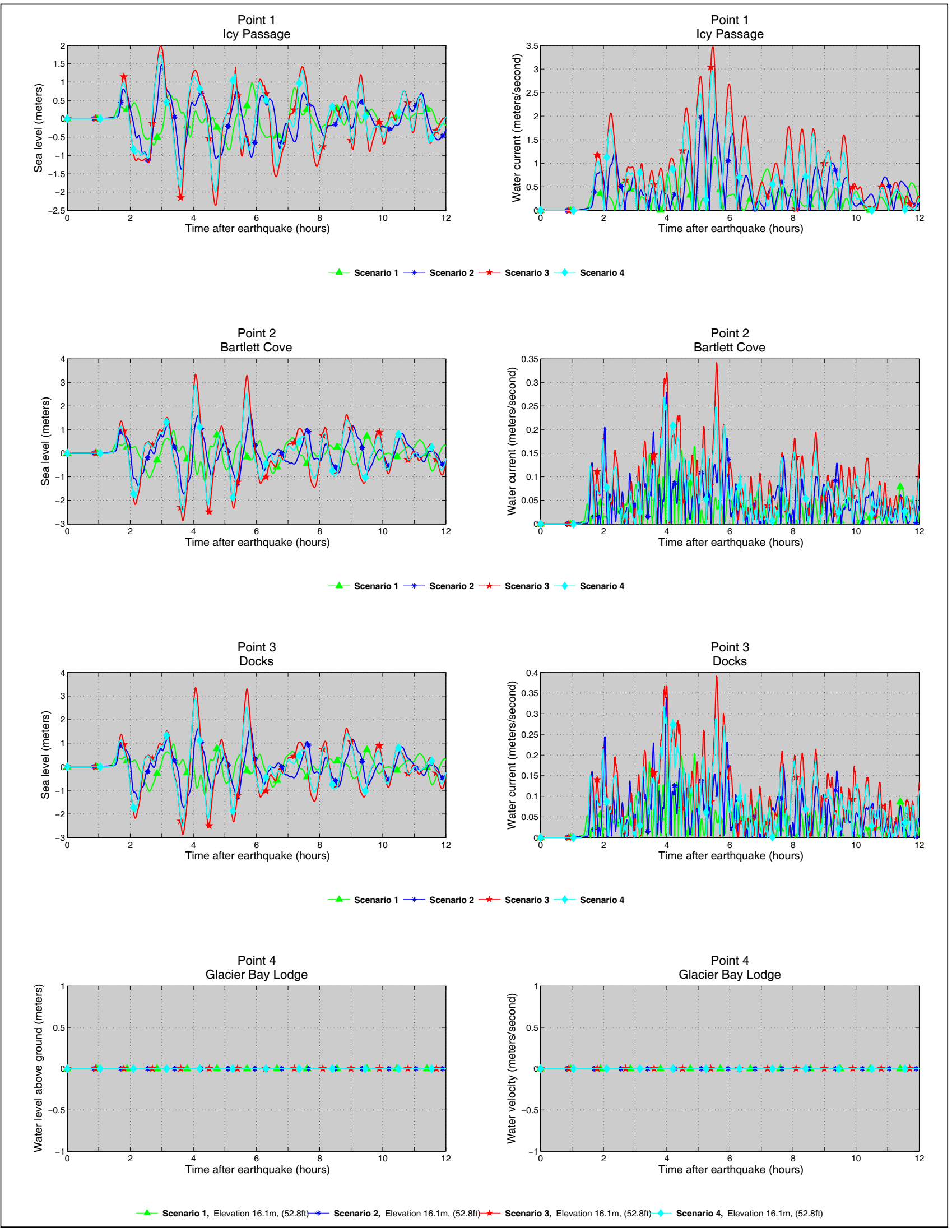

Figure B-2. Time series of the water level and velocity at Gustavus for scenarios 1-4 at the locations shown in figure B-1. 


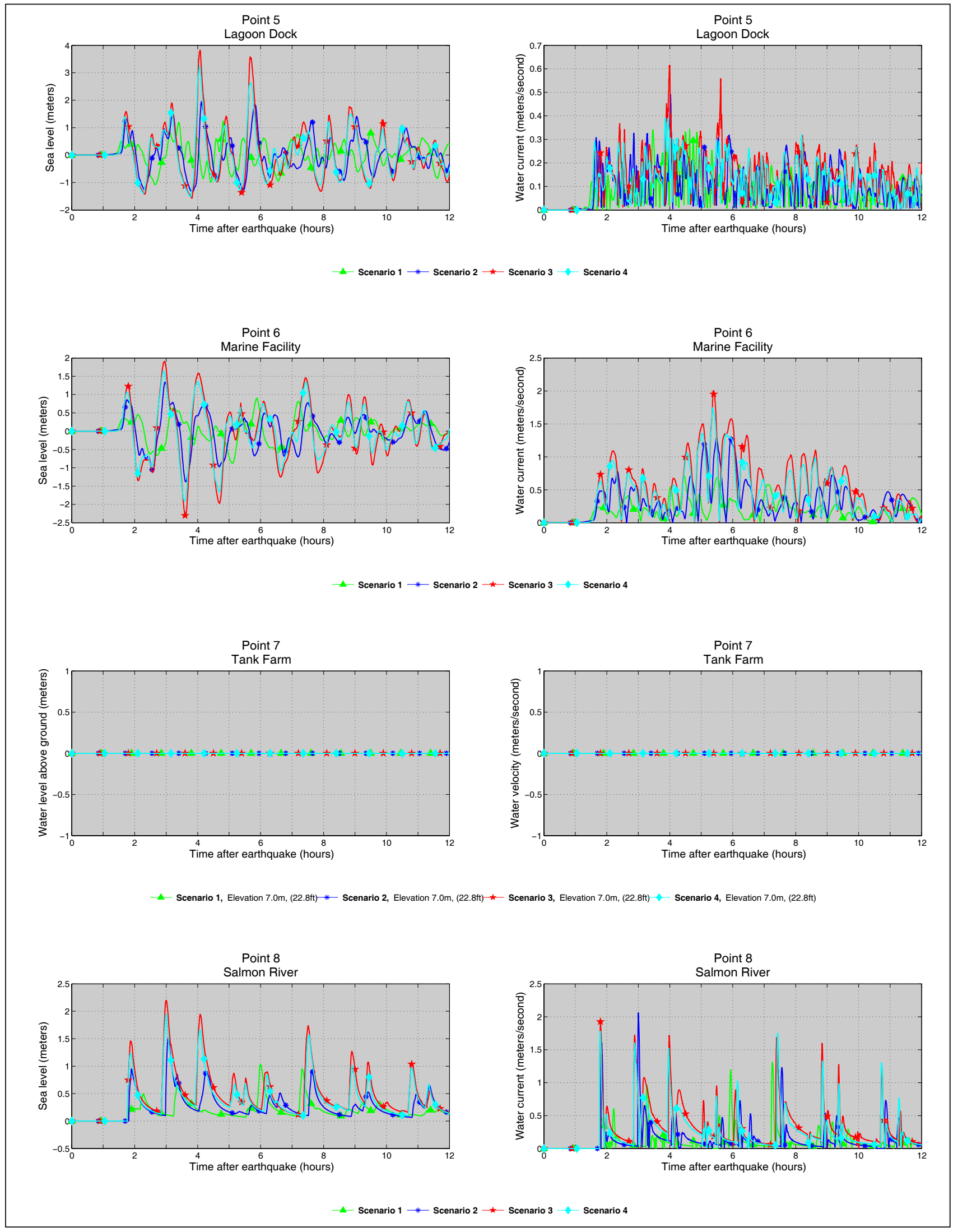

Figure B-2 (continued). Time series of the water level and velocity at Gustavus for scenarios 1-4 at the locations shown in figure B-1. 


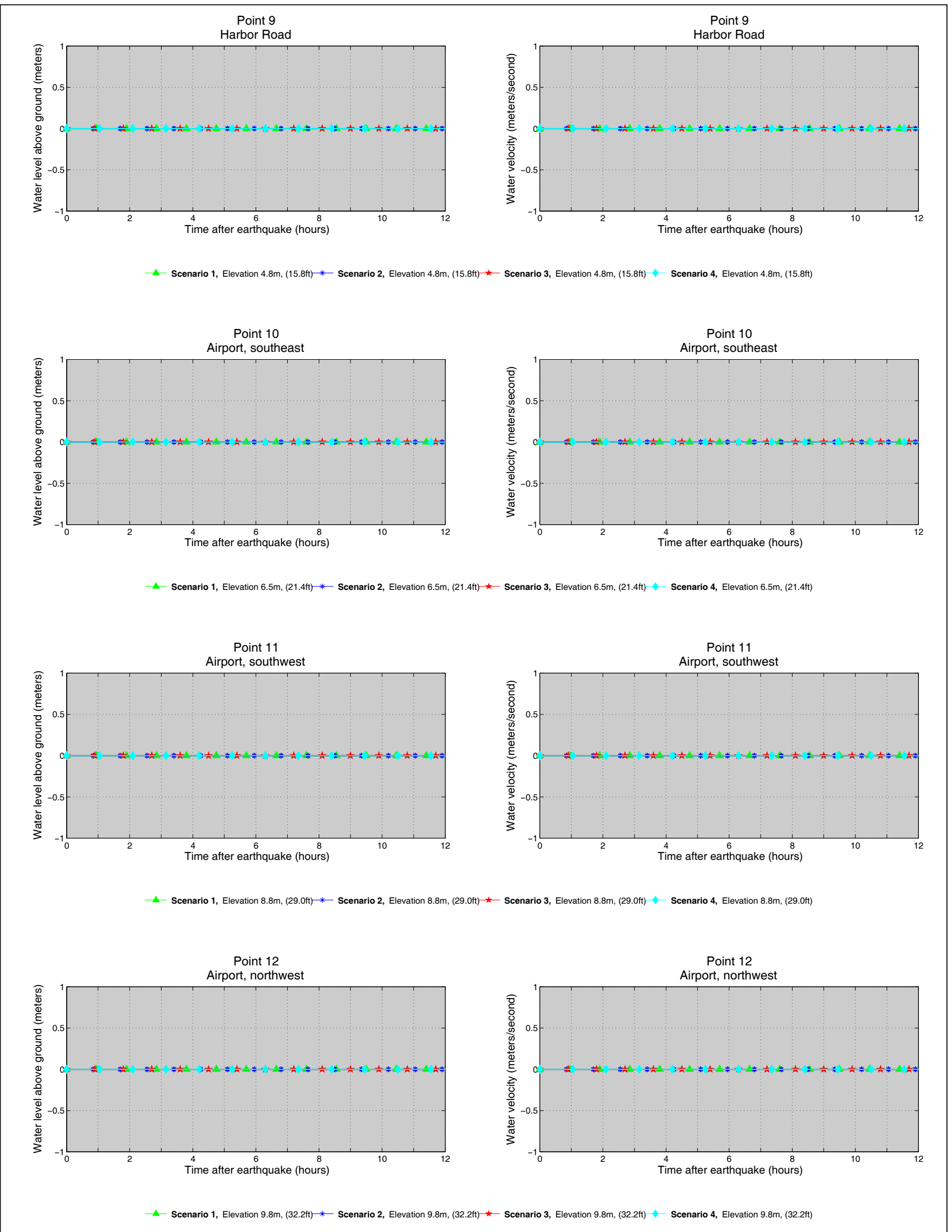

Figure B-2 (continued). Time series of the water level and velocity at Gustavus for scenarios 1-4 at the locations shown in figure $\mathrm{B}-1$. 


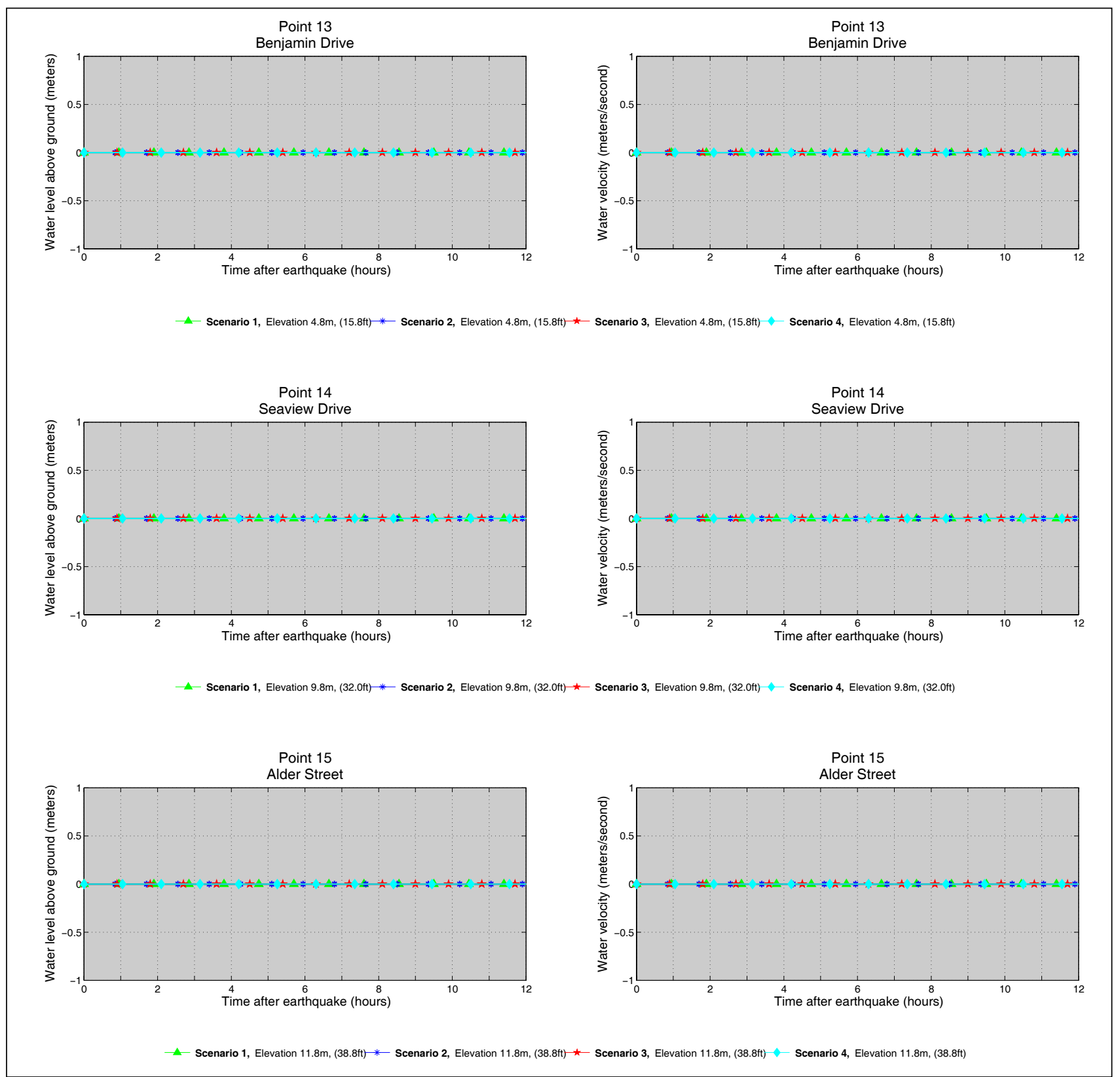

Figure B-2 (continued). Time series of the water level and velocity at Gustavus for scenarios 1-4 at the locations shown in figure B-1. 


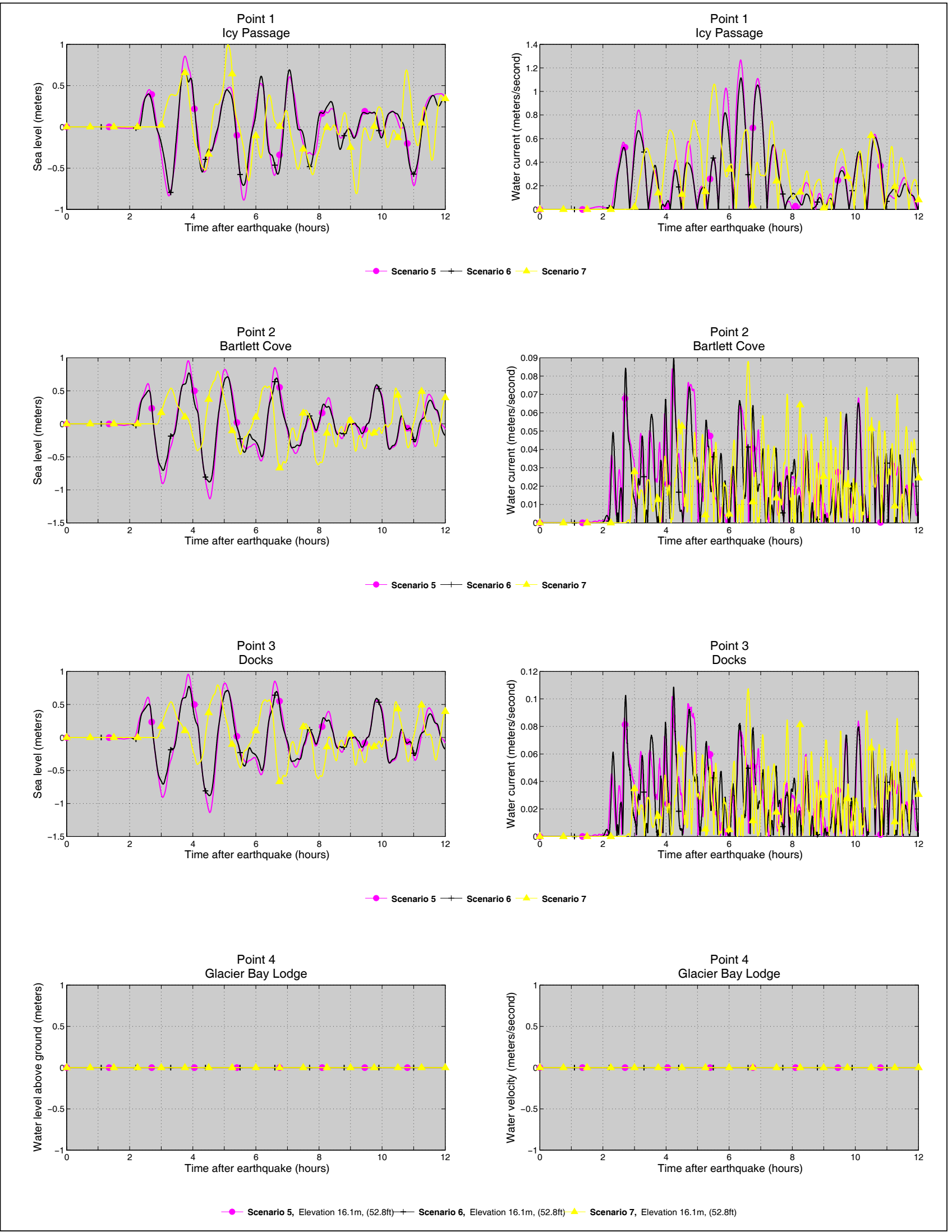

Figure B-3. Time series of the water level and velocity at Gustavus for scenarios 5-7 at the locations shown in figure B-1. 


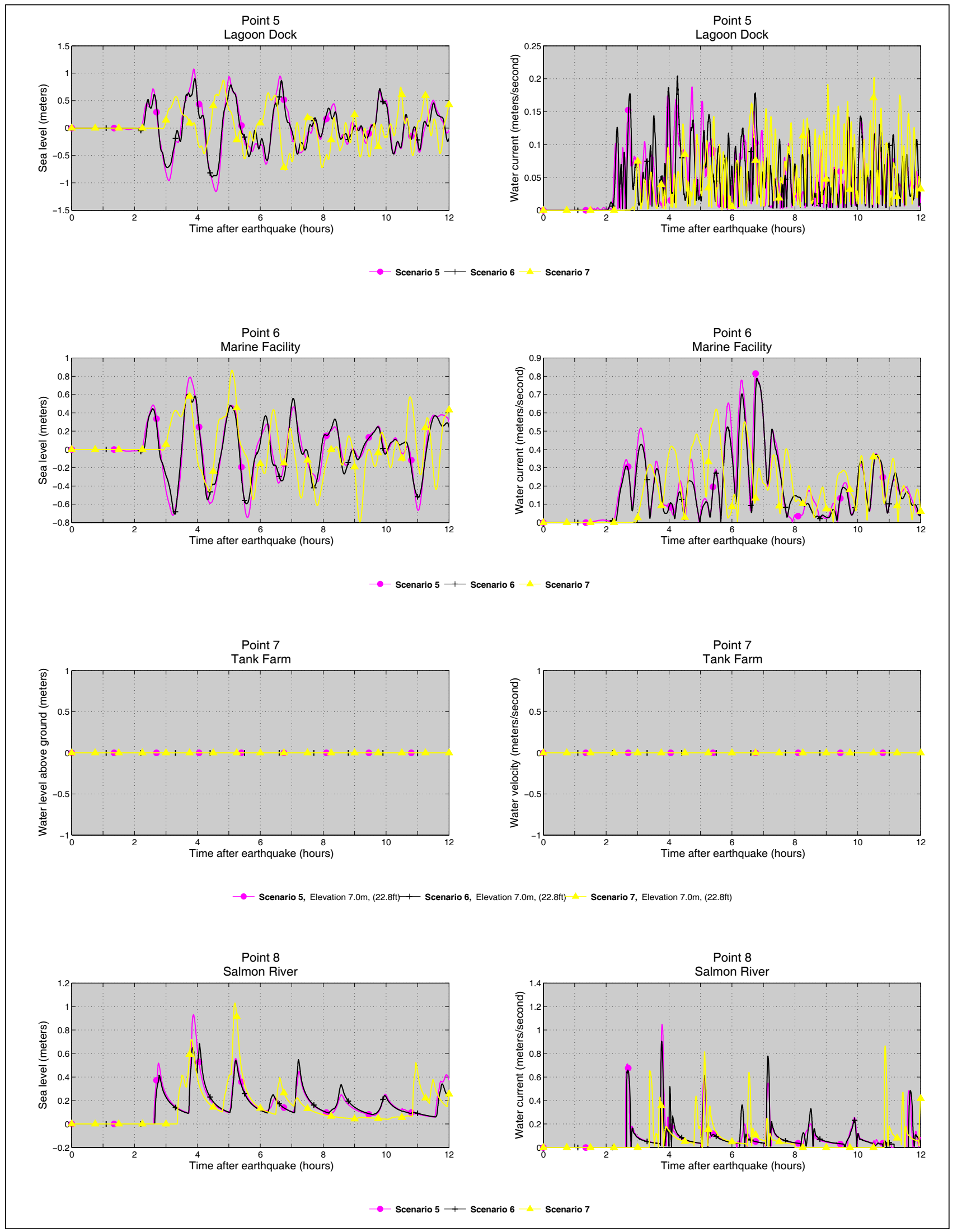

Figure B-3 (continued). Time series of the water level and velocity at Gustavus for scenarios 5-7 at the locations shown in figure B-1. 


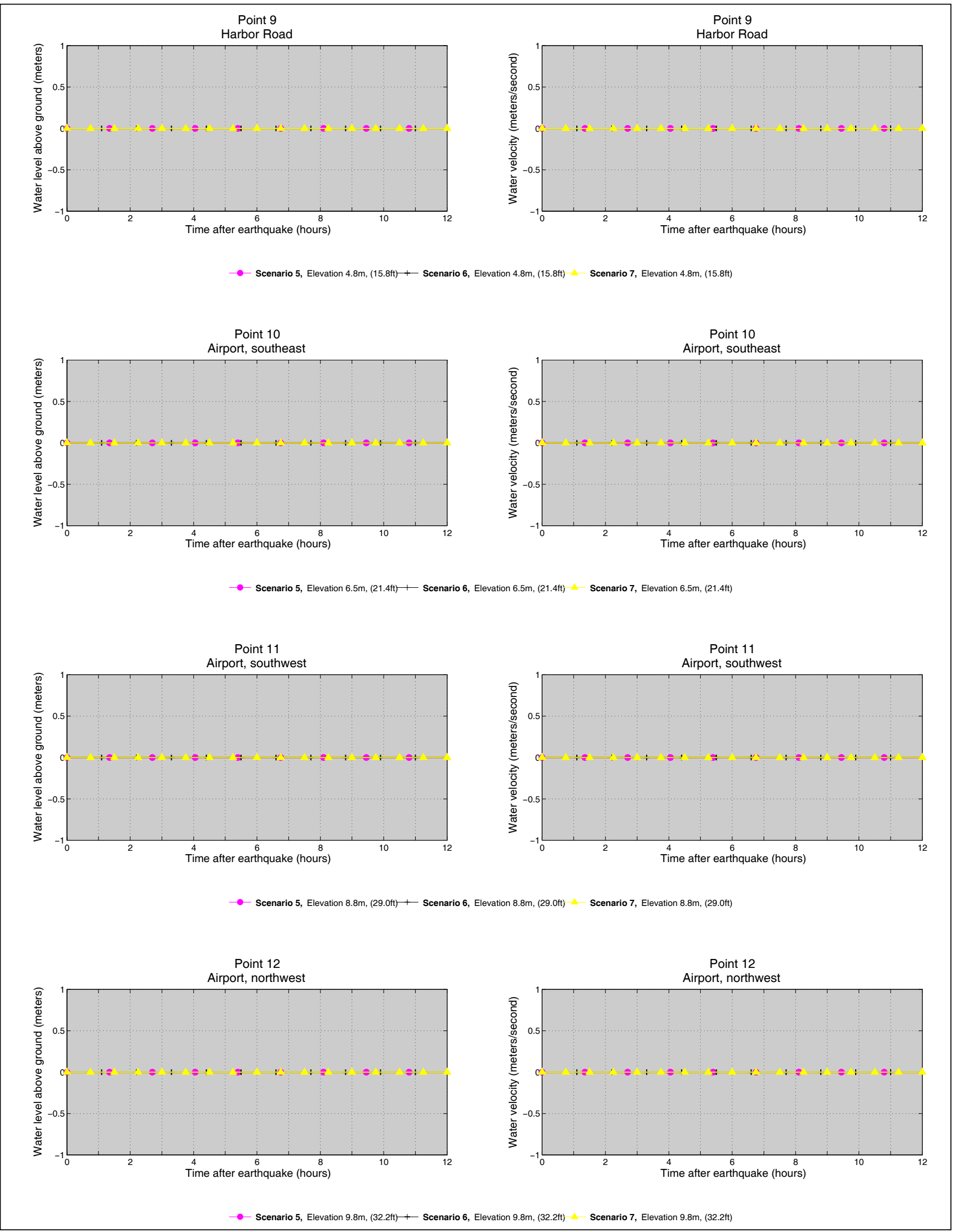

Figure B-3 (continued). Time series of the water level and velocity at Gustavus for scenarios 5-7 at the locations shown in figure B-1. 


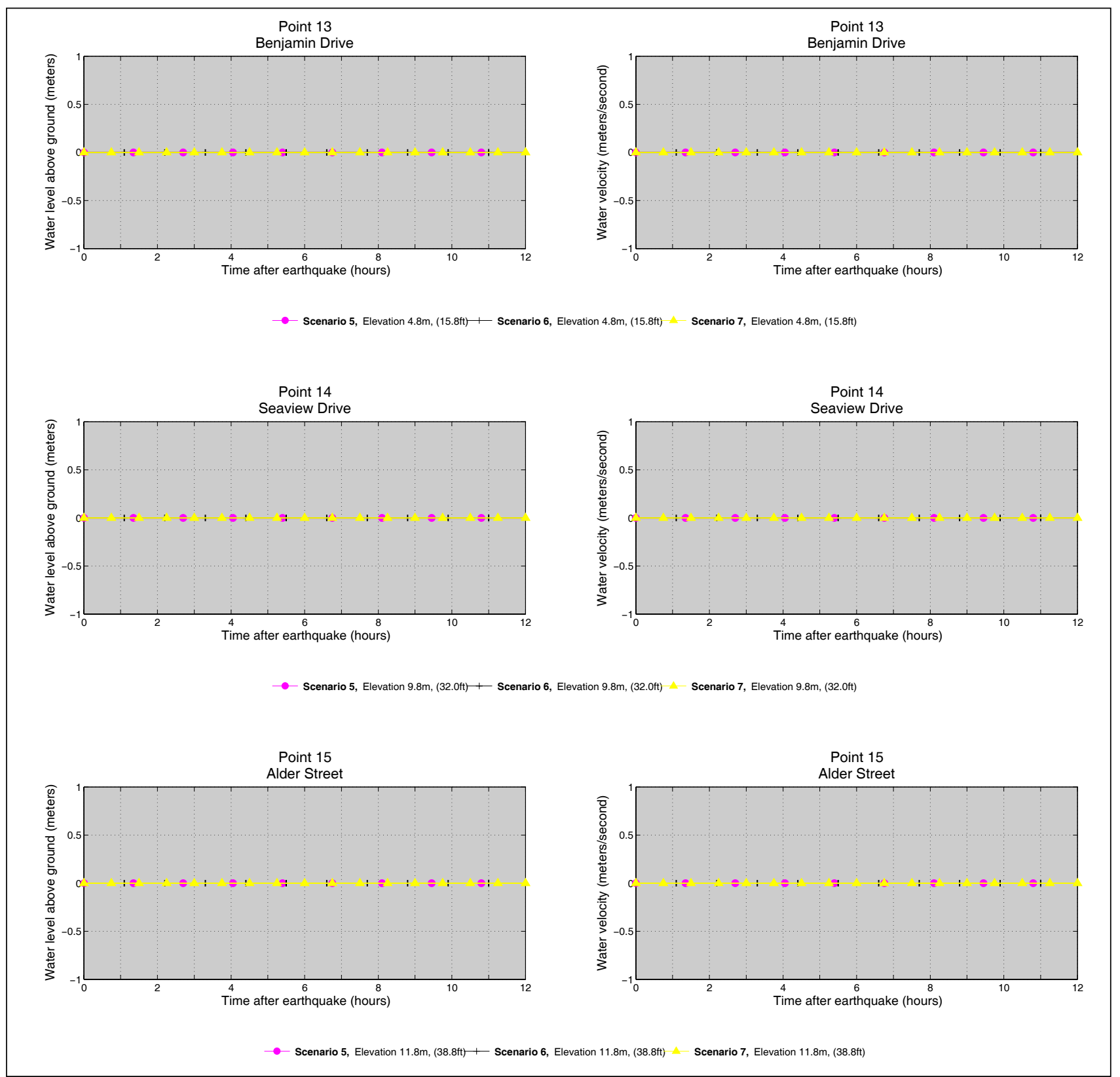

Figure B-3 (continued). Time series of the water level and velocity at Gustavus for scenarios 5-7 at the locations shown in figure B-1. 


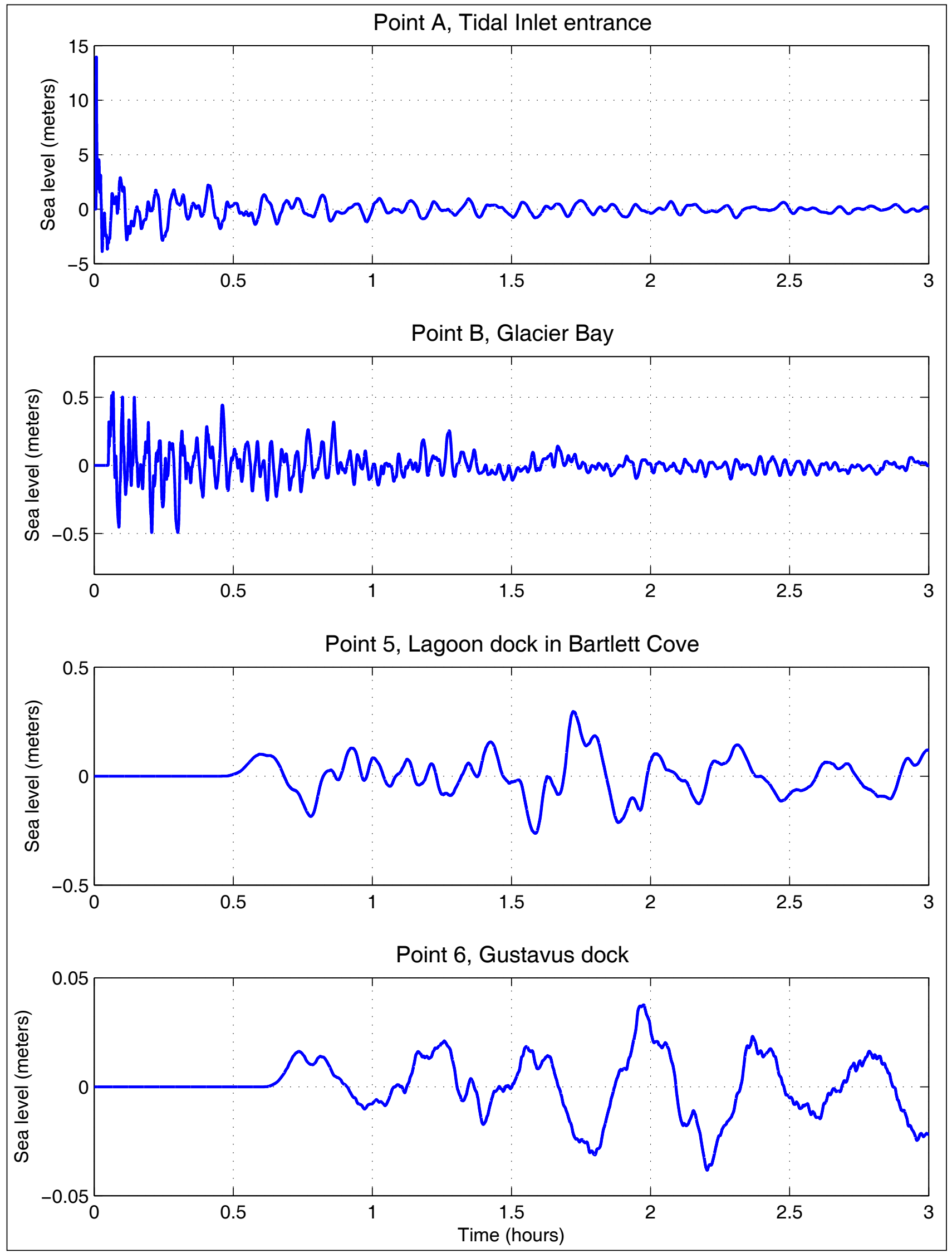

Figure B-4. Time series of the water level and velocity for scenario 9 (subaerial rockslide in Tidal Inlet) at the locations shown in figures B-1 and A-2. 


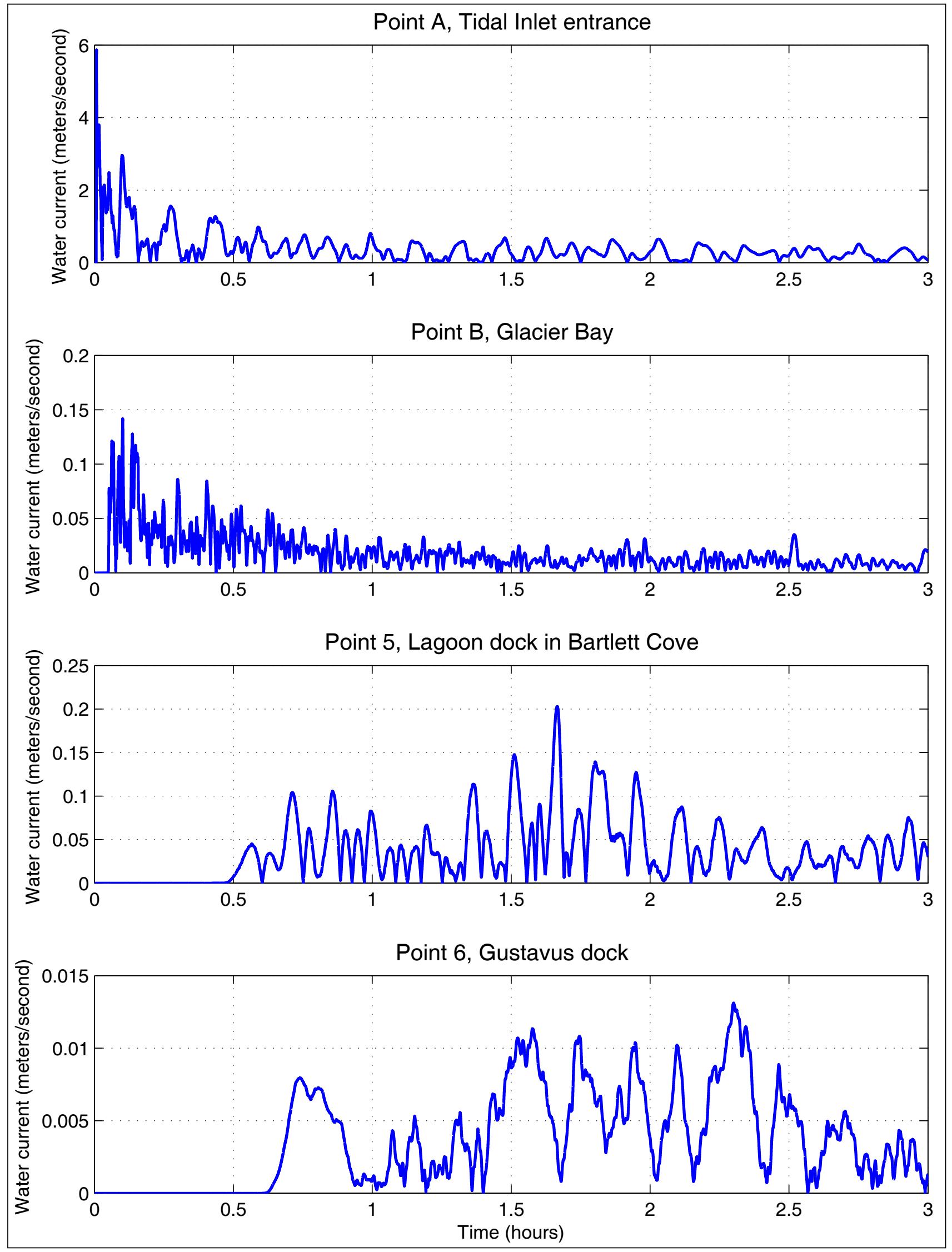

Figure B-4 (continued). Time series of the water level and velocity for scenario 9 (subaerial rockslide in Tidal Inlet) at the locations shown in figures B-1 and A-2. 


\section{APPENDIX C HOONAH}

Table C-1. The longitude and latitude locations of the time series points.

\begin{tabular}{|r|c|c|c|l|}
\hline & $\begin{array}{c}\text { Longitude } \\
\text { (deg. W) }\end{array}$ & $\begin{array}{c}\text { Latitude } \\
\text { (deg. N) }\end{array}$ & $\begin{array}{c}\text { Point location } \\
\text { (Water or Land) }\end{array}$ & Name of the time series point \\
\hline 1 & -135.451389 & 58.149444 & W & North of Hoonah \\
\hline 2 & -135.493333 & 58.131667 & W & Port Frederick \\
\hline 3 & -135.464167 & 58.127222 & W & Ward Cove \\
\hline 4 & -135.466389 & 58.130278 & L & Icy Strait Point \\
\hline 5 & -135.463333 & 58.128889 & W & Old cannery \\
\hline 6 & -135.457222 & 58.116389 & W & Ferry dock \\
\hline 7 & -135.455556 & 58.116944 & L & Cannery Road \\
\hline 8 & -135.454167 & 58.115000 & W & City dock \\
\hline 9 & -135.449444 & 58.112778 & W & Warehouse dock \\
\hline 10 & -135.447500 & 58.112500 & L & Front Street \\
\hline 11 & -135.447778 & 58.110556 & W & City float \\
\hline 12 & -135.447222 & 58.109722 & W & Cold storage \\
\hline 13 & -135.445556 & 58.106389 & W & Boat harbor \\
\hline 14 & -135.440000 & 58.105000 & W & Warehouse \\
\hline 15 & -135.430000 & 58.104167 & L & Icy Strait Lodge \\
\hline 16 & -135.426944 & 58.101667 & W & Hoonah Slough \\
\hline 17 & -135.417778 & 58.095000 & L & Airport west \\
\hline 18 & -135.402500 & 58.096944 & L & Airport east \\
\hline 19 & -135.440556 & 58.089722 & L & Logging camp \\
\hline 20 & -135.444167 & 58.108056 & L & Harbor Way \\
\hline
\end{tabular}

Table C-2. Calculated maximum sea level for all tectonic scenarios at locations listed in table C-1. The maximum water level above ground is provided for onshore locations (L), whereas the maximum water level above the preearthquake MHHW is provided for offshore locations (W).

\begin{tabular}{|c|c|c|c|c|c|c|c|c|c|c|}
\hline & \multirow{3}{*}{$\begin{array}{l}\text { Longitude } \\
\text { (deg. W) }\end{array}$} & \multirow{3}{*}{$\begin{array}{l}\text { Latitude } \\
\text { (deg. N) }\end{array}$} & \multirow{3}{*}{$\begin{array}{c}\text { Water } \\
\text { or } \\
\text { Land }\end{array}$} & \multicolumn{7}{|c|}{ Maximum Water Level Above Ground/Sea Level (m) } \\
\hline & & & & \multicolumn{7}{|c|}{ Scenarios } \\
\hline & & & & 1 & 2 & 3 & 4 & 5 & 6 & 7 \\
\hline 1 & -135.451389 & 58.149444 & W & 0.81 & 0.76 & 0.84 & 0.77 & 0.48 & 0.44 & 1.16 \\
\hline 2 & -135.493333 & 58.131667 & W & 1.07 & 0.98 & 1.57 & 1.19 & 0.90 & 0.77 & 1.57 \\
\hline 3 & -135.464167 & 58.127222 & W & 1.10 & 1.00 & 1.74 & 1.32 & 0.94 & 0.81 & 1.62 \\
\hline 4 & -135.466389 & 58.130278 & $\mathrm{~L}$ & 0.00 & 0.00 & 0.00 & 0.00 & 0.00 & 0.00 & 0.00 \\
\hline 5 & -135.463333 & 58.128889 & W & 1.10 & 1.00 & 1.78 & 1.35 & 0.96 & 0.82 & 1.63 \\
\hline 6 & -135.457222 & 58.116389 & W & 1.15 & 1.05 & 1.89 & 1.46 & 1.03 & 0.89 & 1.71 \\
\hline 7 & -135.455556 & 58.116944 & $\mathrm{~L}$ & 0.00 & 0.00 & 0.00 & 0.00 & 0.00 & 0.00 & 0.00 \\
\hline 8 & -135.454167 & 58.115000 & W & 1.16 & 1.05 & 1.91 & 1.47 & 1.04 & 0.90 & 1.72 \\
\hline 9 & -135.449444 & 58.112778 & W & 1.16 & 1.06 & 1.93 & 1.48 & 1.05 & 0.90 & 1.73 \\
\hline 10 & -135.447500 & 58.112500 & $L$ & 0.00 & 0.00 & 0.00 & 0.00 & 0.00 & 0.00 & 0.00 \\
\hline 11 & -135.447778 & 58.110556 & W & 1.17 & 1.06 & 1.94 & 1.49 & 1.05 & 0.91 & 1.73 \\
\hline 12 & -135.447222 & 58.109722 & W & 1.17 & 1.06 & 1.95 & 1.50 & 1.06 & 0.91 & 1.73 \\
\hline 13 & -135.445556 & 58.106389 & W & 1.20 & 1.09 & 2.00 & 1.55 & 1.10 & 0.94 & 1.78 \\
\hline 14 & -135.440000 & 58.105000 & $W$ & 1.25 & 1.16 & 2.11 & 1.65 & 1.17 & 1.00 & 1.83 \\
\hline 15 & -135.430000 & 58.104167 & $\mathrm{~L}$ & 0.00 & 0.00 & 0.00 & 0.00 & 0.00 & 0.00 & 0.00 \\
\hline 16 & -135.426944 & 58.101667 & W & 1.41 & 1.27 & 2.42 & 1.94 & 1.28 & 1.08 & 2.00 \\
\hline 17 & -135.417778 & 58.095000 & $L$ & 0.00 & 0.00 & 0.00 & 0.00 & 0.00 & 0.00 & 0.00 \\
\hline 18 & -135.402500 & 58.096944 & $\mathrm{~L}$ & 0.00 & 0.00 & 0.00 & 0.00 & 0.00 & 0.00 & 0.00 \\
\hline 19 & -135.440556 & 58.089722 & $L$ & 0.00 & 0.00 & 0.00 & 0.00 & 0.00 & 0.00 & 0.00 \\
\hline 20 & -135.444167 & 58.108056 & $\mathrm{~L}$ & 0.00 & 0.00 & 0.00 & 0.00 & 0.00 & 0.00 & 0.00 \\
\hline
\end{tabular}


Table C-3. Calculated maximum water current velocities for all tectonic scenarios at locations listed in table C-1. The onshore locations are indicated by L, whereas the offshore locations are marked by W.

\begin{tabular}{|c|c|c|c|c|c|c|c|c|c|c|}
\hline & \multirow{3}{*}{$\begin{array}{l}\text { Longitude } \\
\text { (deg. W) }\end{array}$} & \multirow{3}{*}{$\begin{array}{l}\text { Latitude } \\
\text { (deg. N) }\end{array}$} & \multirow{3}{*}{$\begin{array}{l}\text { Water } \\
\text { or } \\
\text { Land }\end{array}$} & \multicolumn{7}{|c|}{ Maximum Water Velocity (m/second) } \\
\hline & & & & \multicolumn{7}{|c|}{ Scenarios } \\
\hline & & & & 1 & 2 & 3 & 4 & 5 & 6 & 7 \\
\hline 1 & -135.451389 & 58.149444 & W & 0.74 & 0.84 & 1.64 & 1.16 & 0.73 & 0.64 & 1.20 \\
\hline 2 & -135.493333 & 58.131667 & W & 0.58 & 0.74 & 1.28 & 0.98 & 0.62 & 0.54 & 1.03 \\
\hline 3 & -135.464167 & 58.127222 & W & 0.25 & 0.30 & 1.15 & 0.82 & 0.25 & 0.24 & 0.78 \\
\hline 4 & -135.466389 & 58.130278 & $\mathrm{~L}$ & 0.00 & 0.00 & 0.00 & 0.00 & 0.00 & 0.00 & 0.00 \\
\hline 5 & -135.463333 & 58.128889 & W & 0.00 & 0.00 & 0.00 & 0.00 & 0.00 & 0.00 & 0.00 \\
\hline 6 & -135.457222 & 58.116389 & W & 0.22 & 0.26 & 0.46 & 0.34 & 0.22 & 0.19 & 0.34 \\
\hline 7 & -135.455556 & 58.116944 & $\mathrm{~L}$ & 0.00 & 0.00 & 0.00 & 0.00 & 0.00 & 0.00 & 0.00 \\
\hline 8 & -135.454167 & 58.115000 & W & 0.18 & 0.21 & 0.36 & 0.28 & 0.18 & 0.15 & 0.27 \\
\hline 9 & -135.449444 & 58.112778 & W & 0.09 & 0.12 & 0.19 & 0.16 & 0.09 & 0.07 & 0.15 \\
\hline 10 & -135.447500 & 58.112500 & $L$ & 0.00 & 0.00 & 0.00 & 0.00 & 0.00 & 0.00 & 0.00 \\
\hline 11 & -135.447778 & 58.110556 & $W$ & 0.09 & 0.12 & 0.19 & 0.17 & 0.08 & 0.06 & 0.13 \\
\hline 12 & -135.447222 & 58.109722 & $w$ & 0.12 & 0.16 & 0.33 & 0.26 & 0.10 & 0.09 & 0.19 \\
\hline 13 & -135.445556 & 58.106389 & $W$ & 0.17 & 0.22 & 0.36 & 0.26 & 0.16 & 0.13 & 0.29 \\
\hline 14 & -135.440000 & 58.105000 & W & 0.66 & 0.83 & 1.13 & 1.05 & 0.64 & 0.51 & 0.88 \\
\hline 15 & -135.430000 & 58.104167 & $L$ & 0.00 & 0.00 & 0.00 & 0.00 & 0.00 & 0.00 & 0.00 \\
\hline 16 & -135.426944 & 58.101667 & W & 1.05 & 1.11 & 1.40 & 1.33 & 0.95 & 0.85 & 1.19 \\
\hline 17 & -135.417778 & 58.095000 & $\mathrm{~L}$ & 0.00 & 0.00 & 0.00 & 0.00 & 0.00 & 0.00 & 0.00 \\
\hline 18 & -135.402500 & 58.096944 & $\mathrm{~L}$ & 0.00 & 0.00 & 0.00 & 0.00 & 0.00 & 0.00 & 0.00 \\
\hline 19 & -135.440556 & 58.089722 & $\mathrm{~L}$ & 0.00 & 0.00 & 0.00 & 0.00 & 0.00 & 0.00 & 0.00 \\
\hline 20 & -135.444167 & 58.108056 & $\mathrm{~L}$ & 0.00 & 0.00 & 0.00 & 0.00 & 0.00 & 0.00 & 0.00 \\
\hline
\end{tabular}




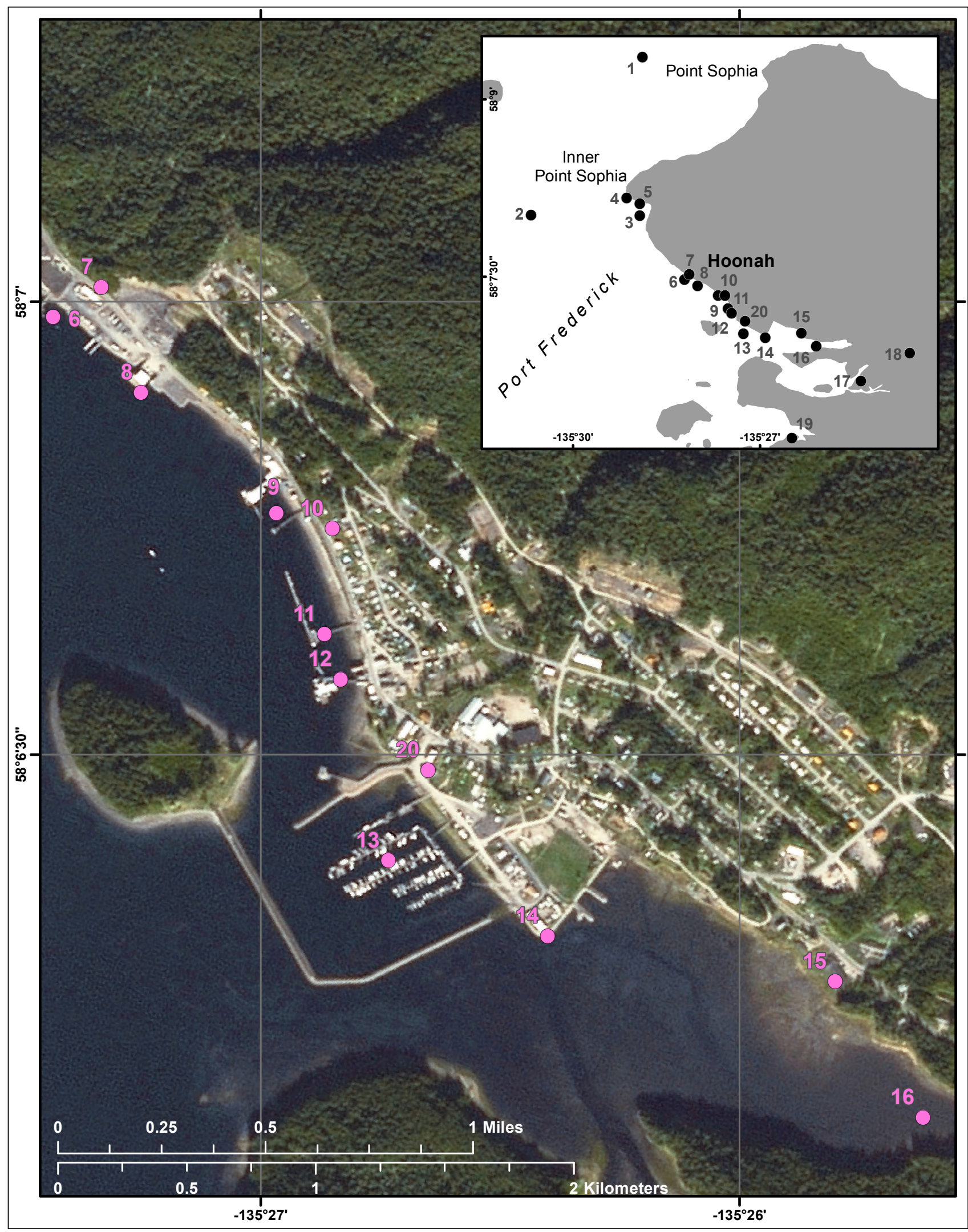

Figure C-1. Locations of time-series points in the Hoonah high-resolution grid. 


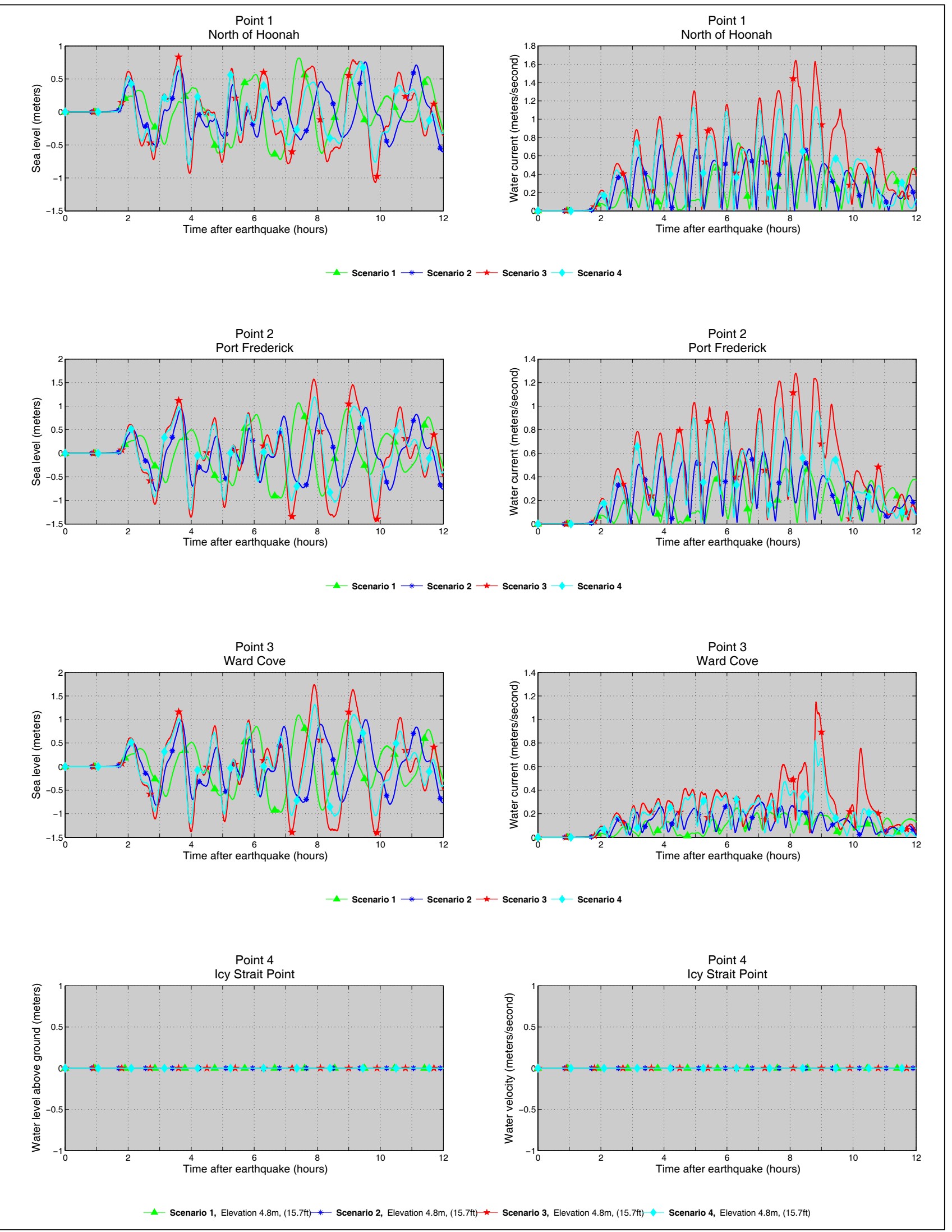

Figure C-2. Time series of the water level and velocity at Hoonah for scenarios 1-4 at the locations shown in figure C-1. 


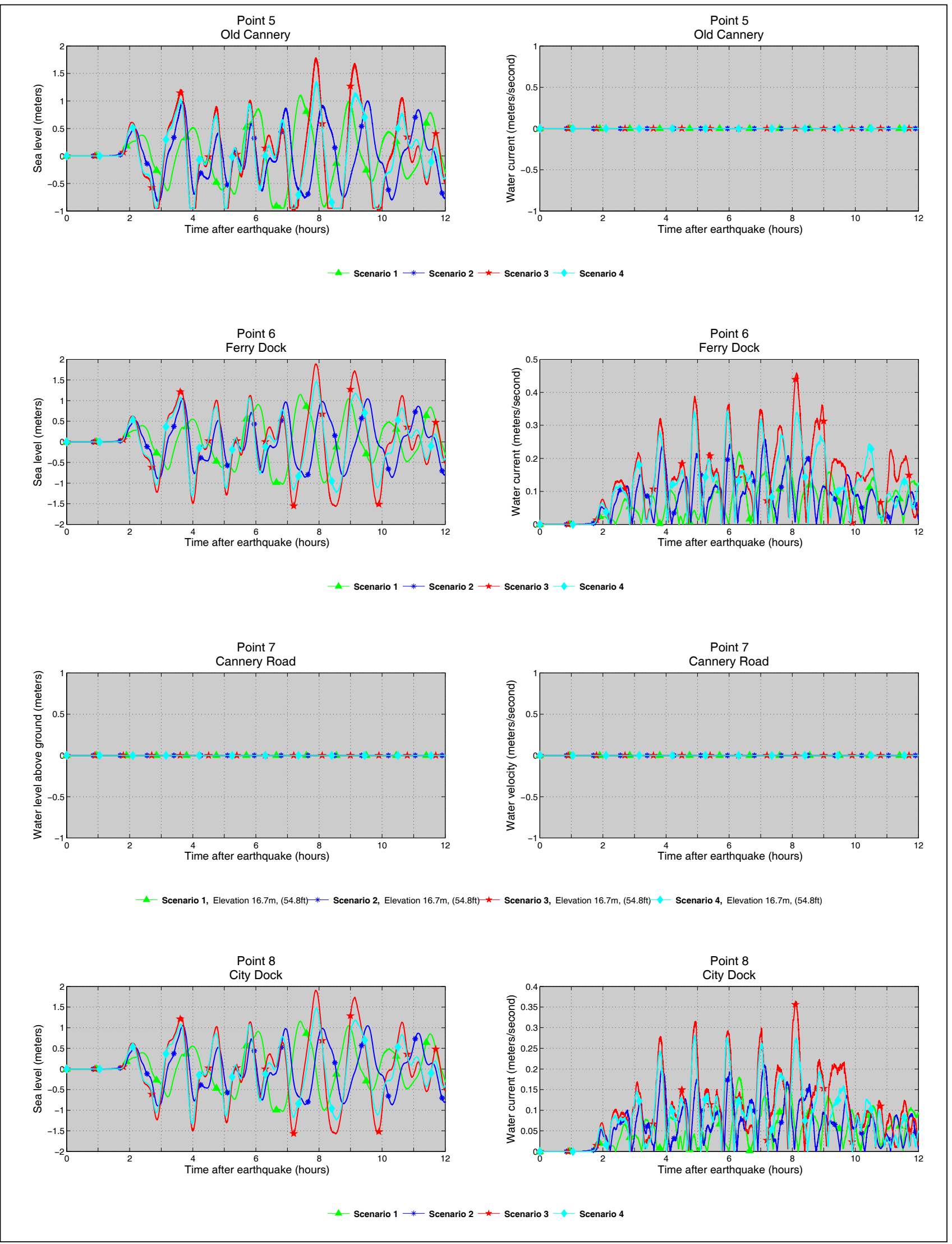

Figure C-2 (continued). Time series of the water level and velocity at Hoonah for scenarios 1-4 at the locations shown in figure $\mathrm{C}-1$. 

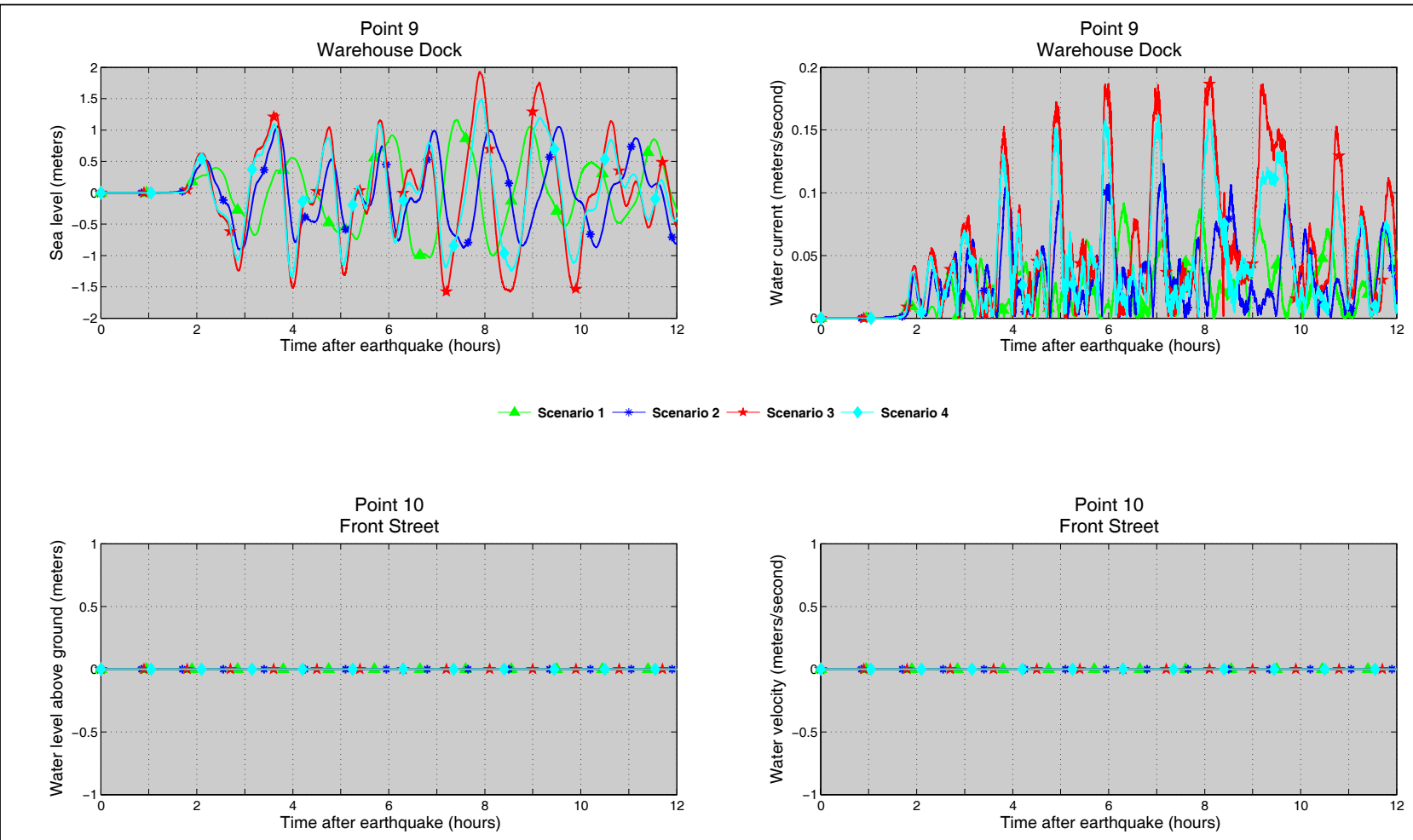

- Scenario 1, Elevation 12.8m, (42.1ft) * Scenario 2, Elevation 12.8m, (42.1ft) * Scenario 3, Elevation 12.8m, (42.1ft) - Scenario 4, Elevation 12.8m, (42.1ft)
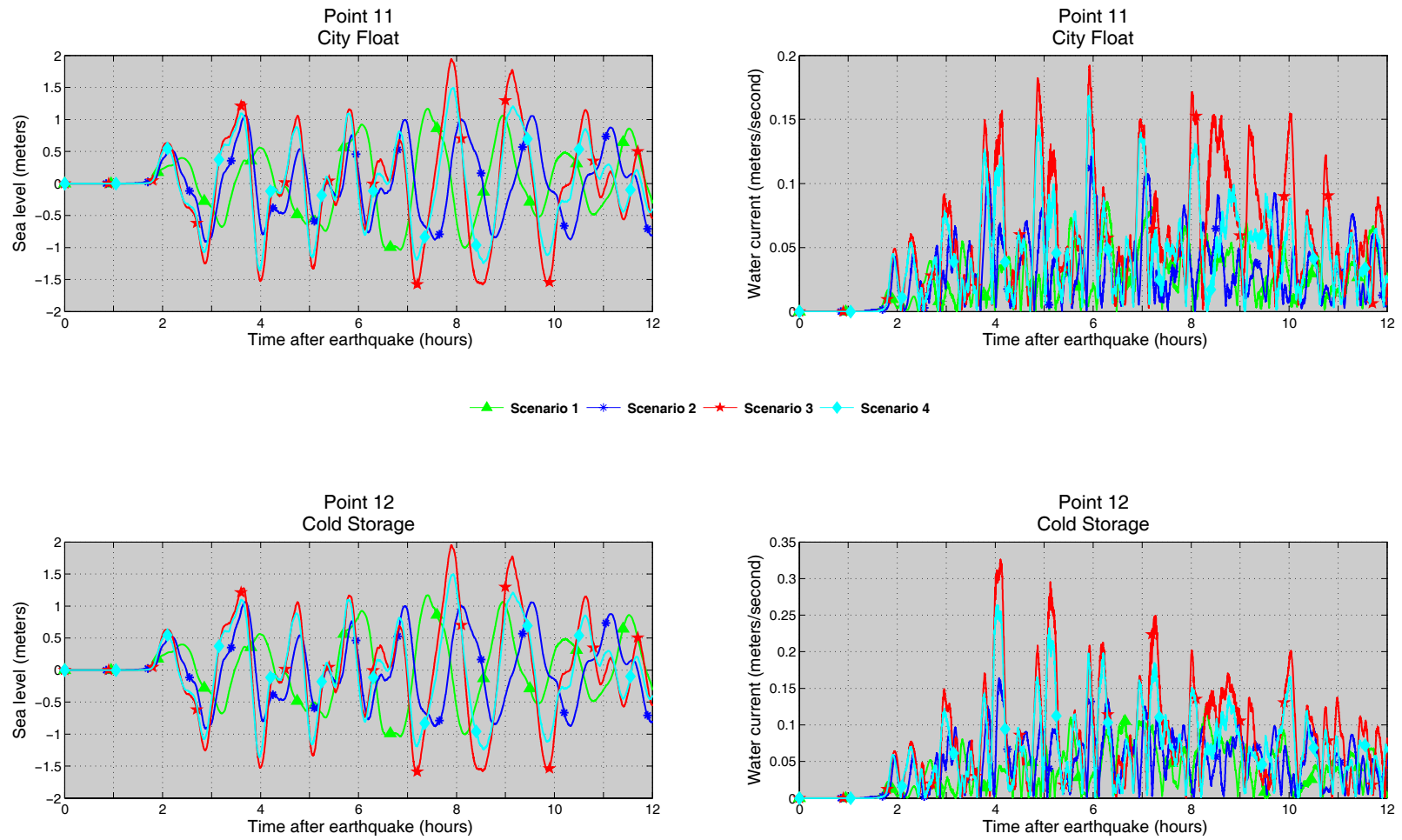

Scenario 1 * Scenario 2 * Scenario $3-$ Scenario 4

Figure C-2 (continued). Time series of the water level and velocity at Hoonah for scenarios 1-4 at the locations shown in figure C-1. 


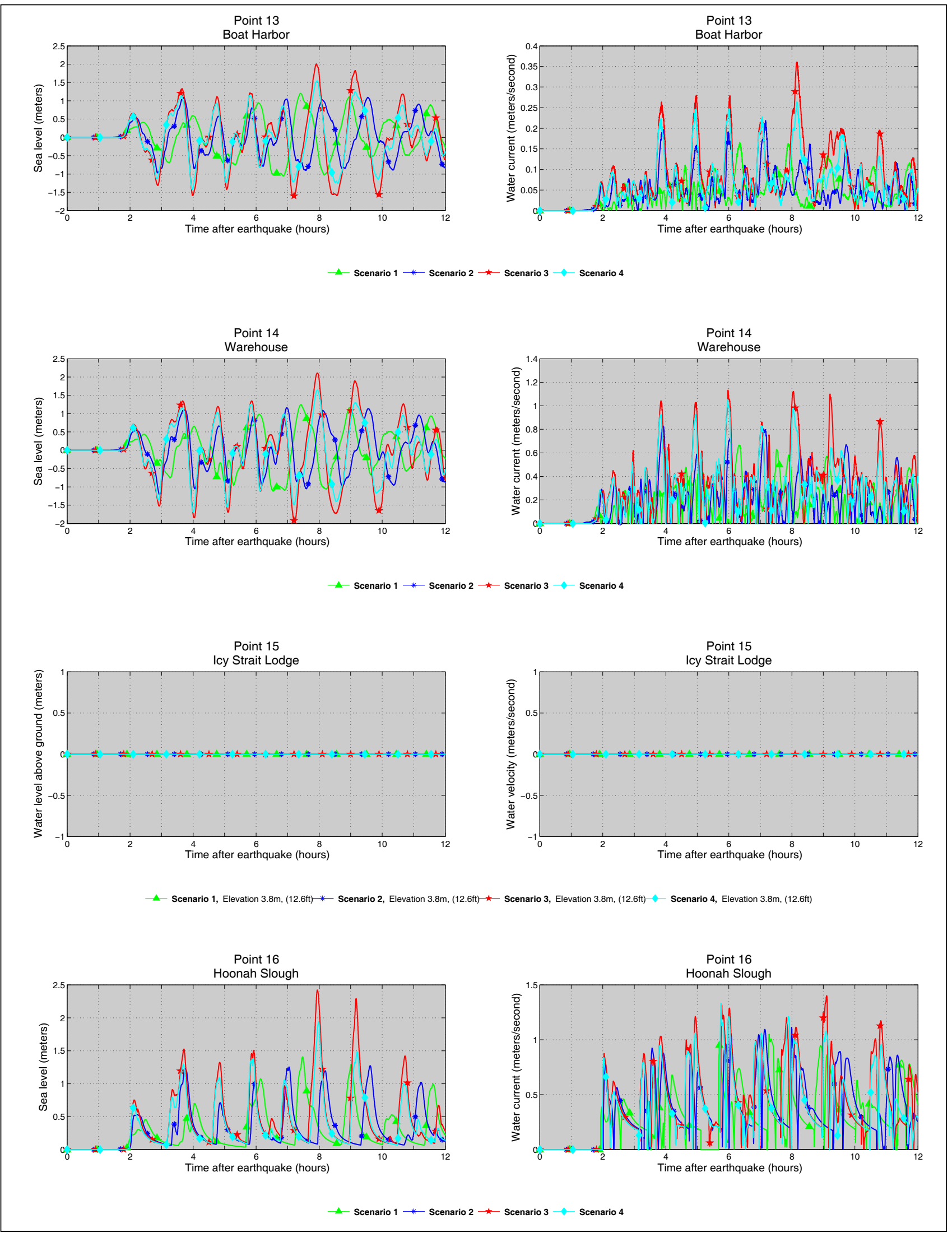

Figure C-2 (continued). Time series of the water level and velocity at Hoonah for scenarios 1-4 at the locations shown in figure $\mathrm{C}-1$. 


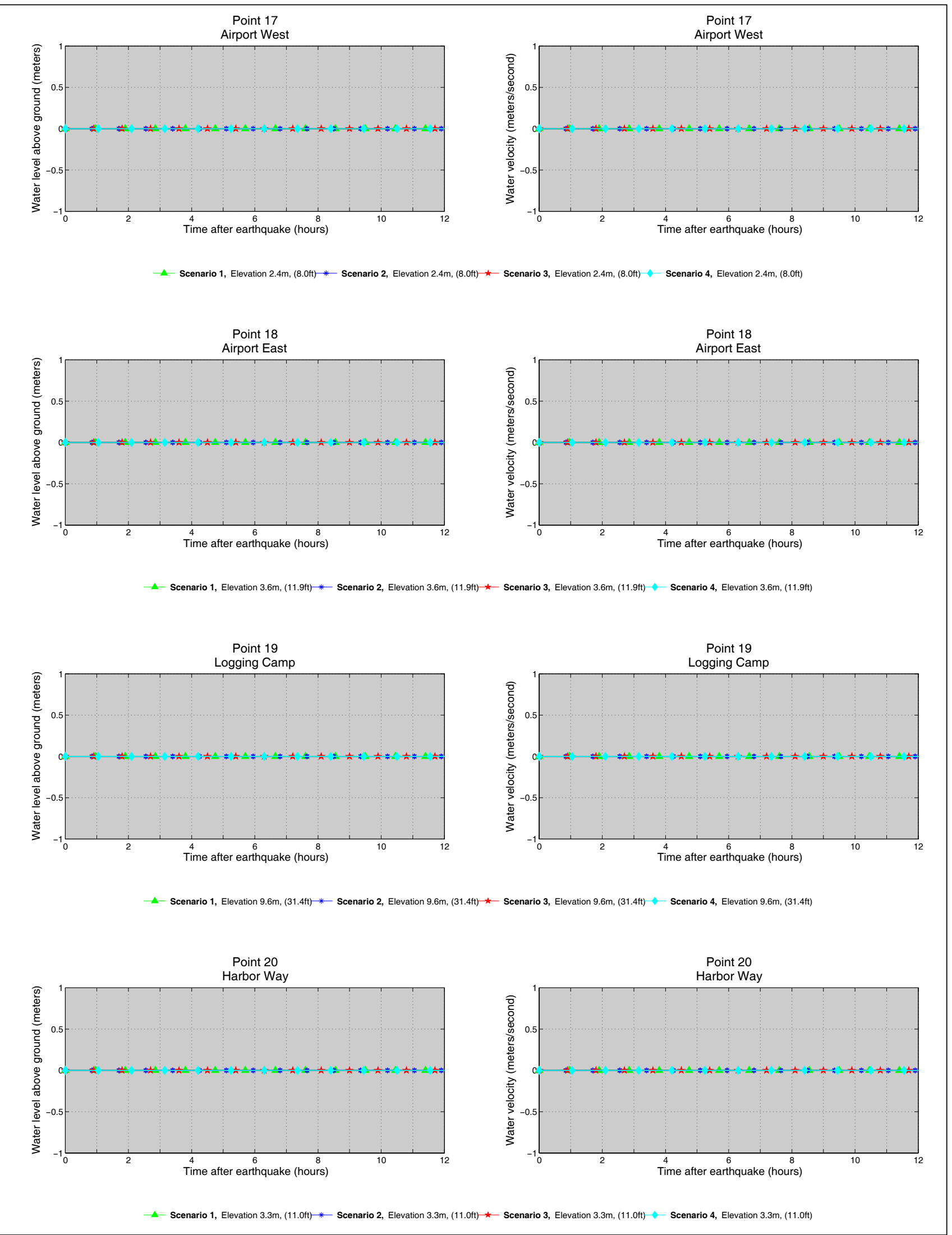

Figure C-2 (continued). Time series of the water level and velocity at Hoonah for scenarios 1-4 at the locations shown in figure $\mathrm{C}-1$. 


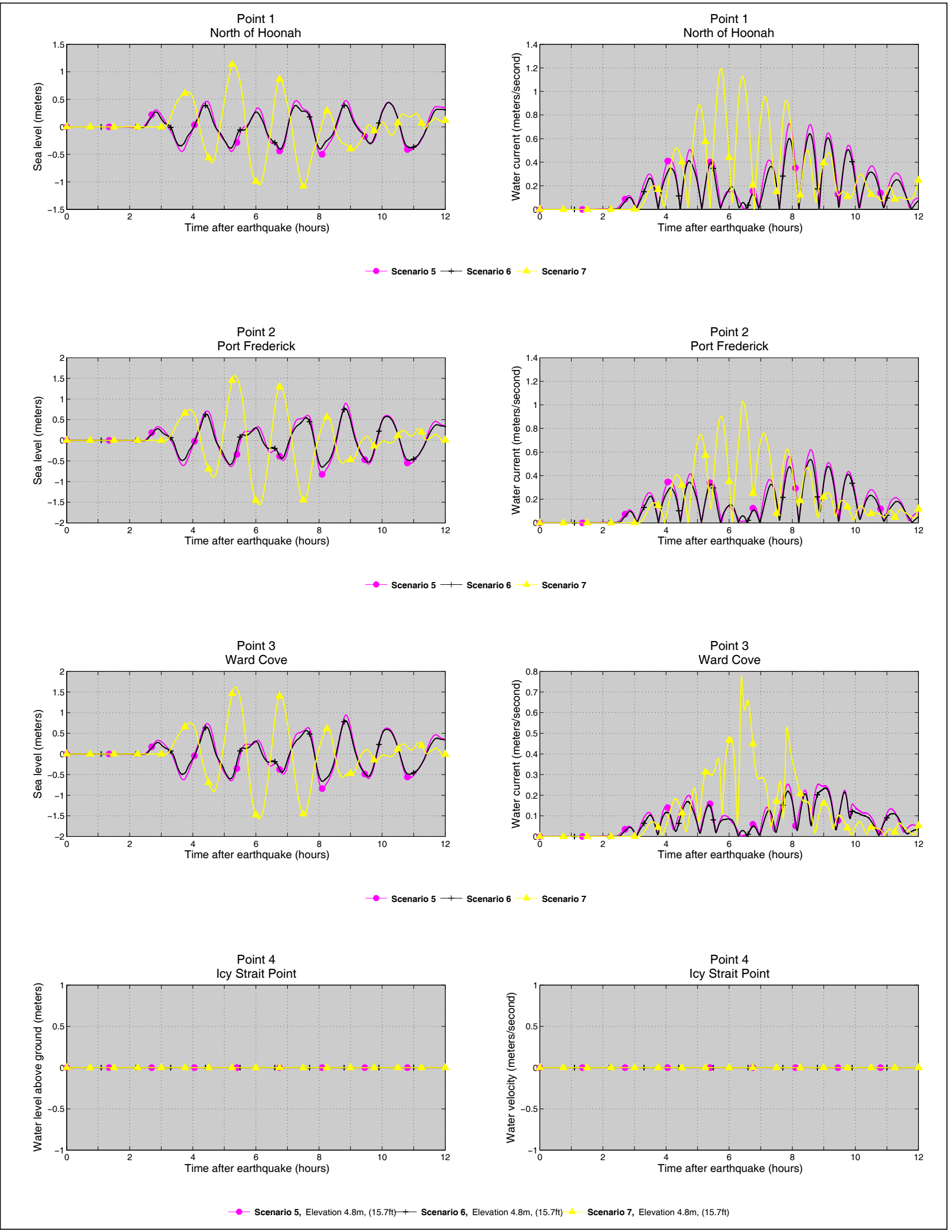

Figure C-3. Time series of the water level and velocity at Hoonah for scenarios 5-7 at the locations shown in figure C-1. 


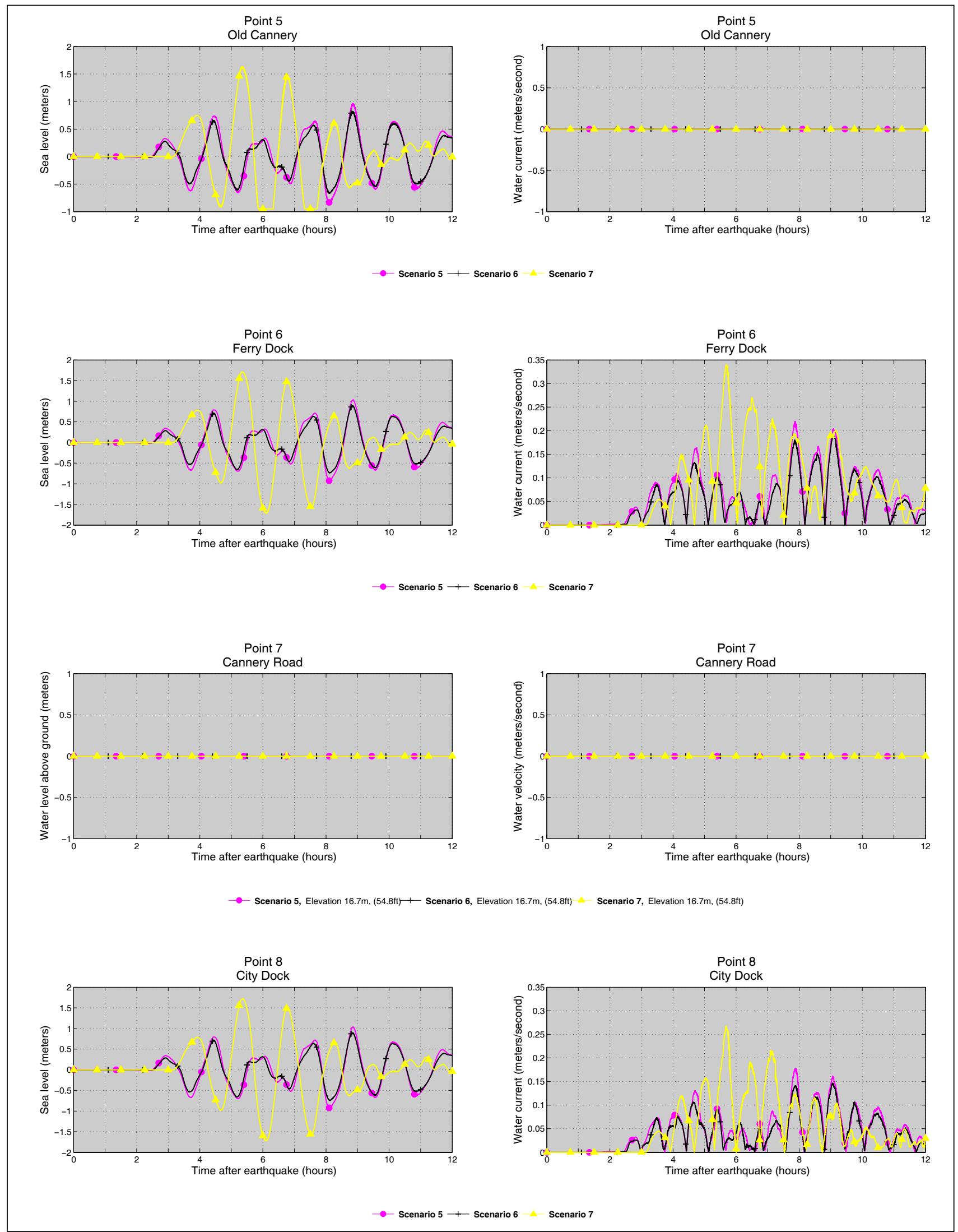

Figure C-3 (continued). Time series of the water level and velocity at Hoonah for scenarios 5-7 at the locations shown in figure $\mathrm{C}-1$. 


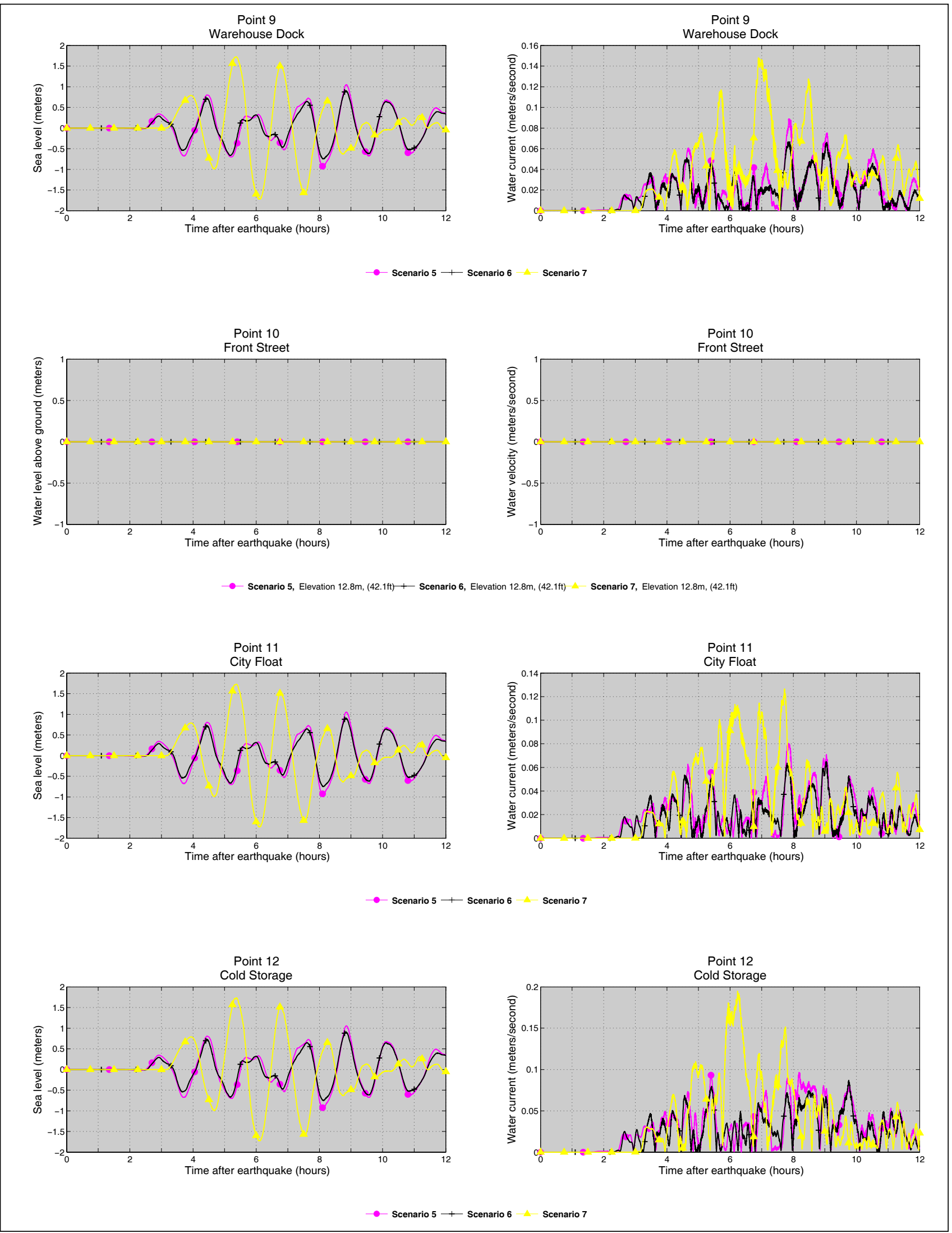

Figure C-3 (continued). Time series of the water level and velocity at Hoonah for scenarios 5-7 at the locations shown in figure $\mathrm{C}-1$. 


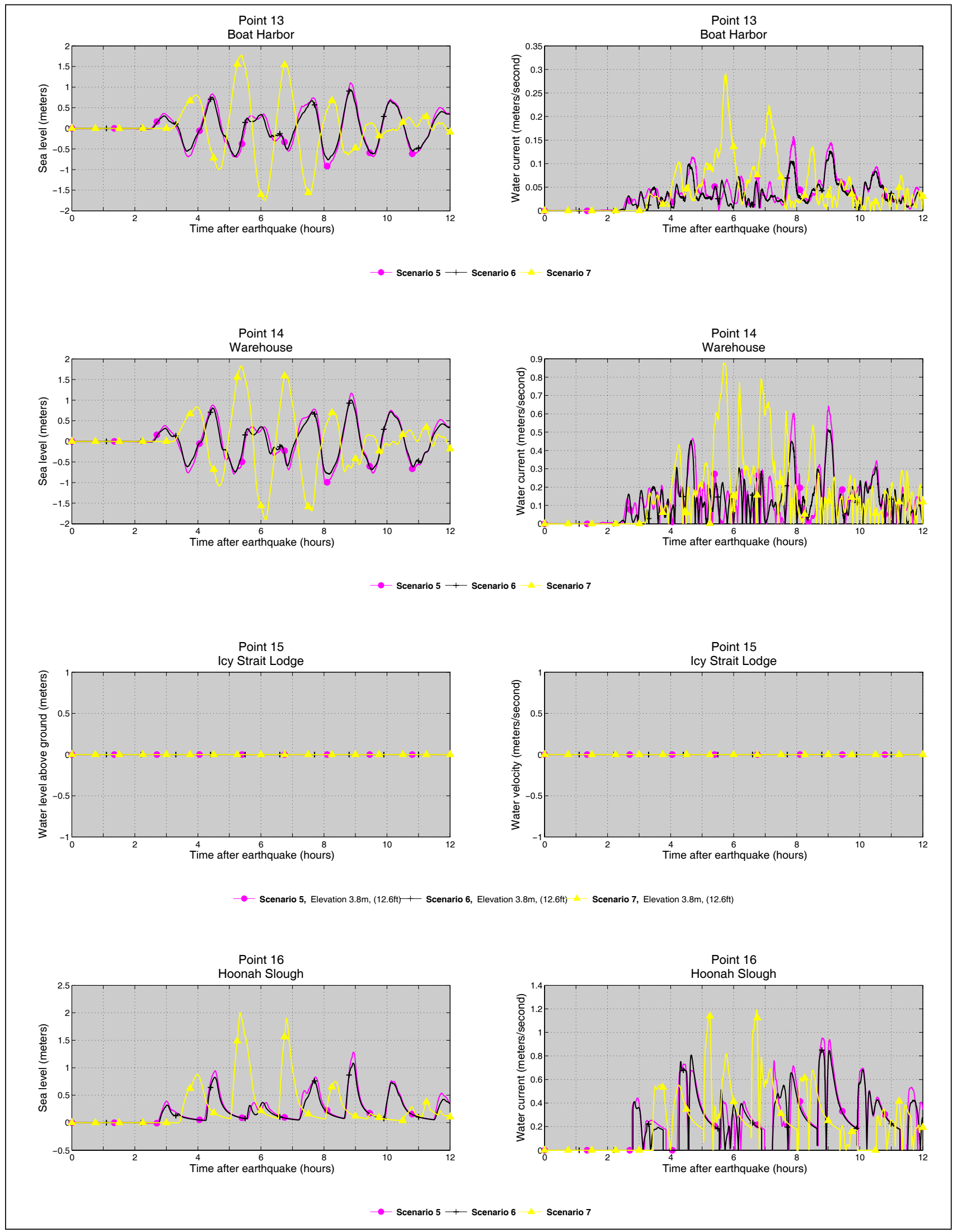

Figure C-3 (continued). Time series of the water level and velocity at Hoonah for scenarios 5-7 at the locations shown in figure $\mathrm{C}-1$. 


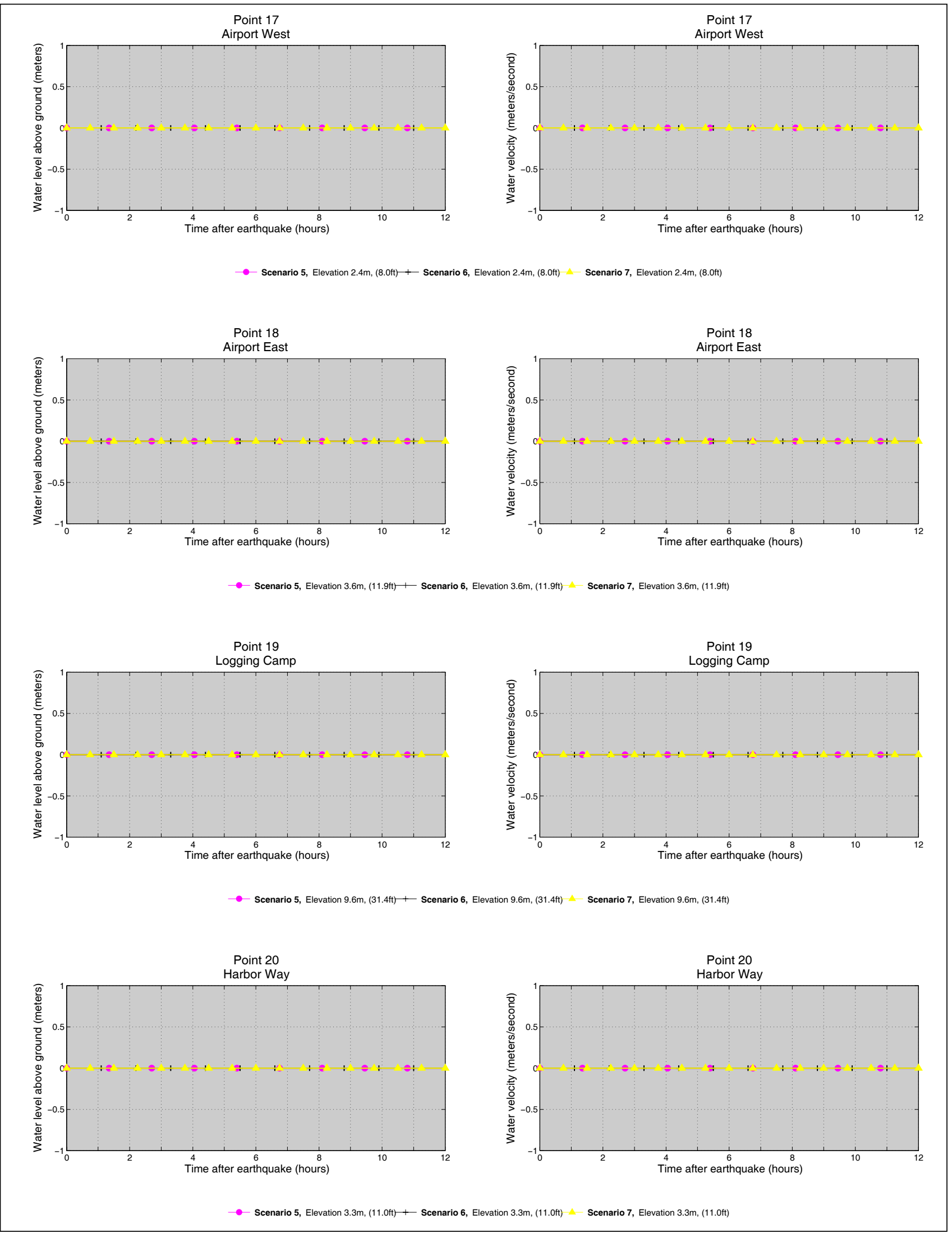

Figure C-3 (continued). Time series of the water level and velocity at Hoonah for scenarios 5-7 at the locations shown in figure $\mathrm{C}-1$. 

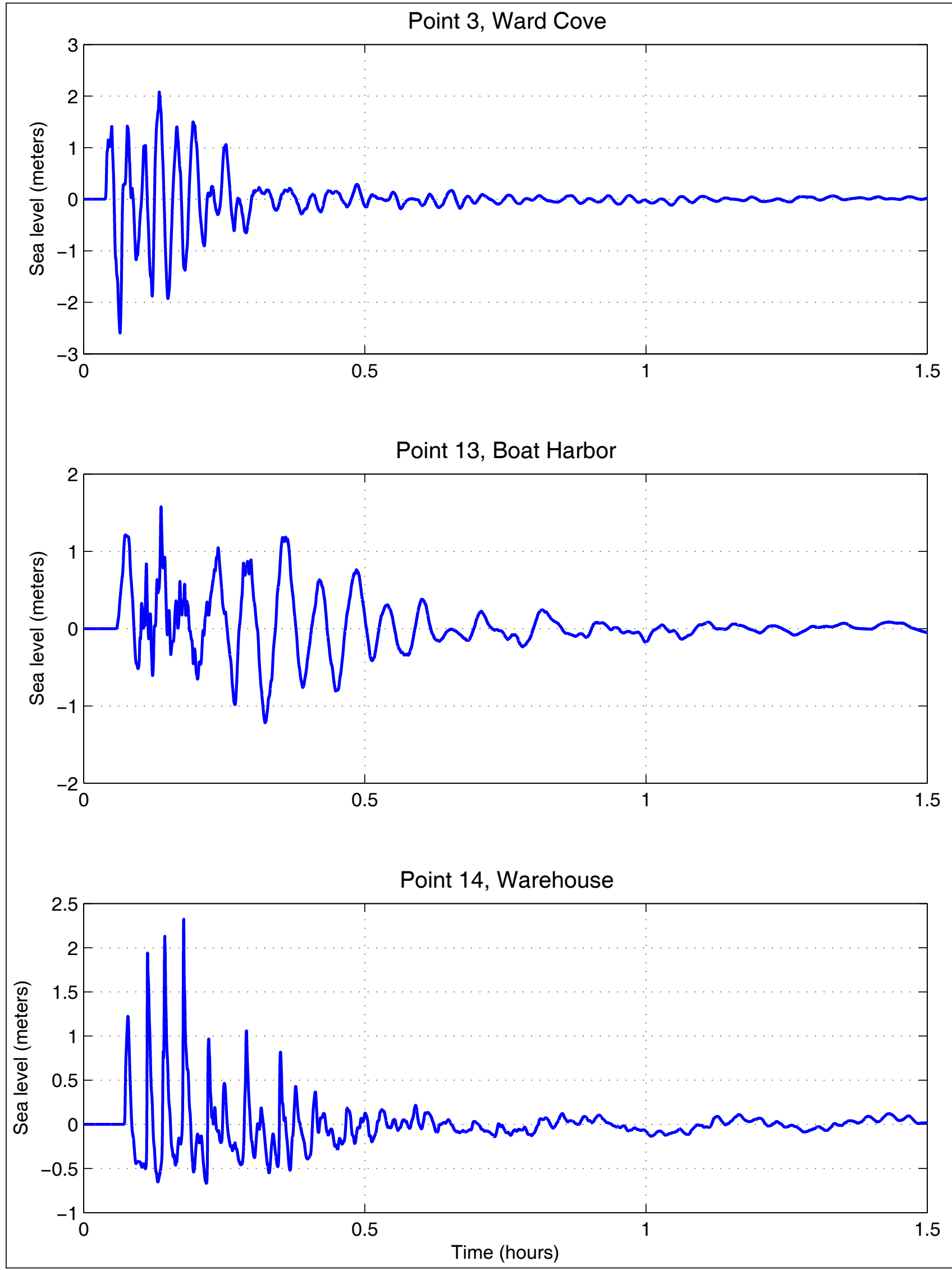

Figure C-4. Time series of the water level and velocity for scenario 10 at the locations shown in figure C-1. 


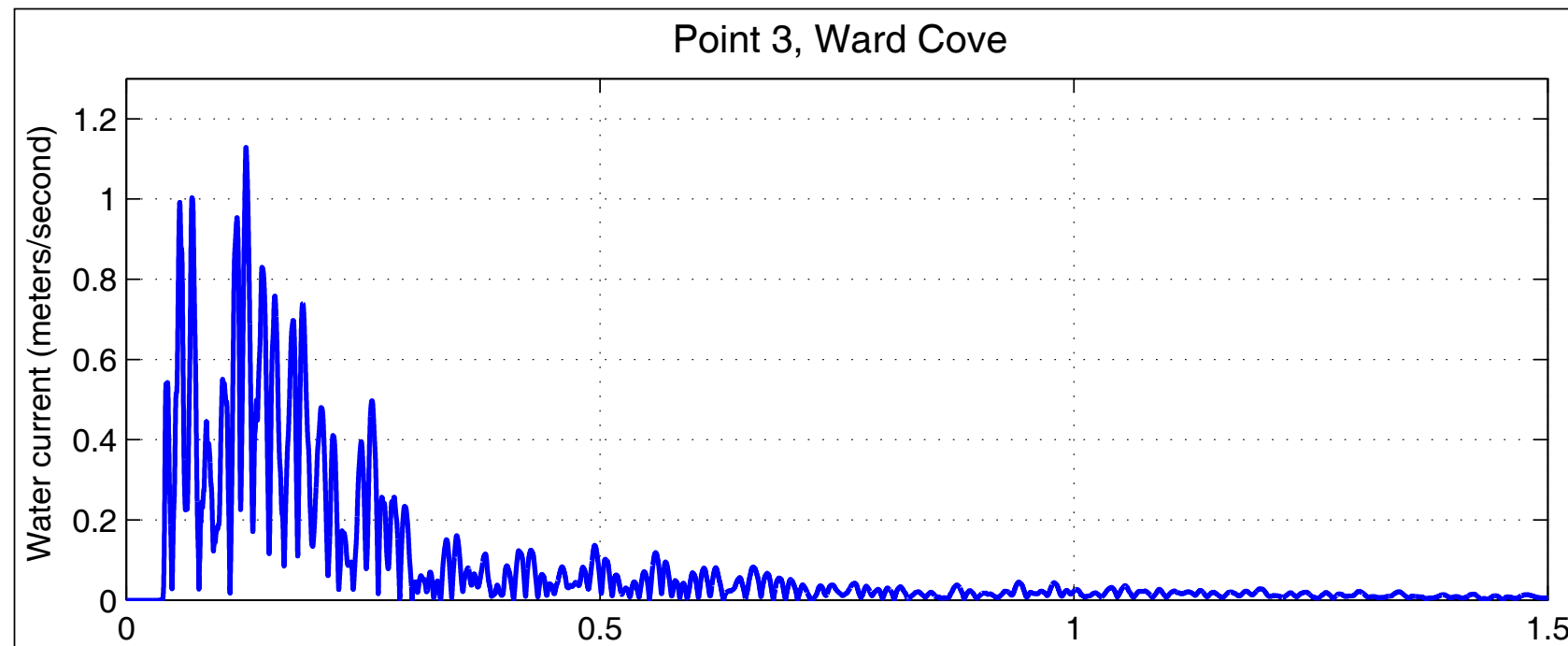

Point 13, Boat Harbor

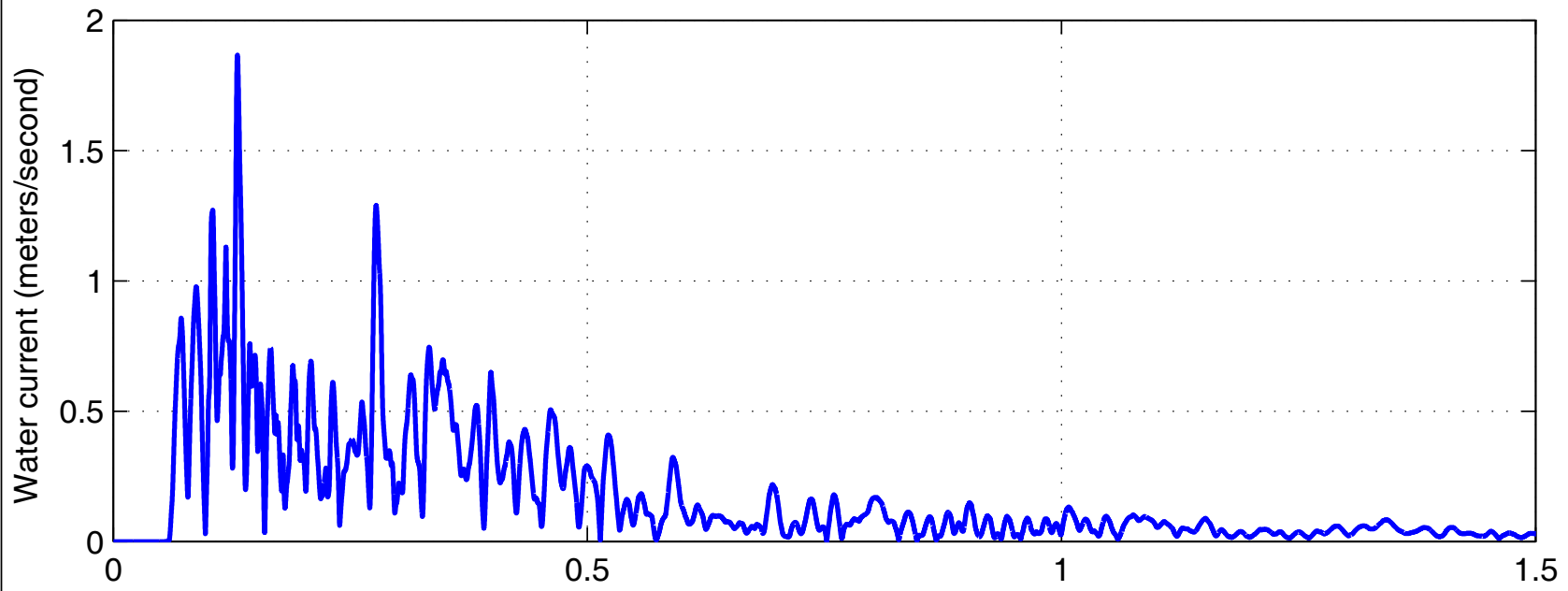

Point 14, Warehouse

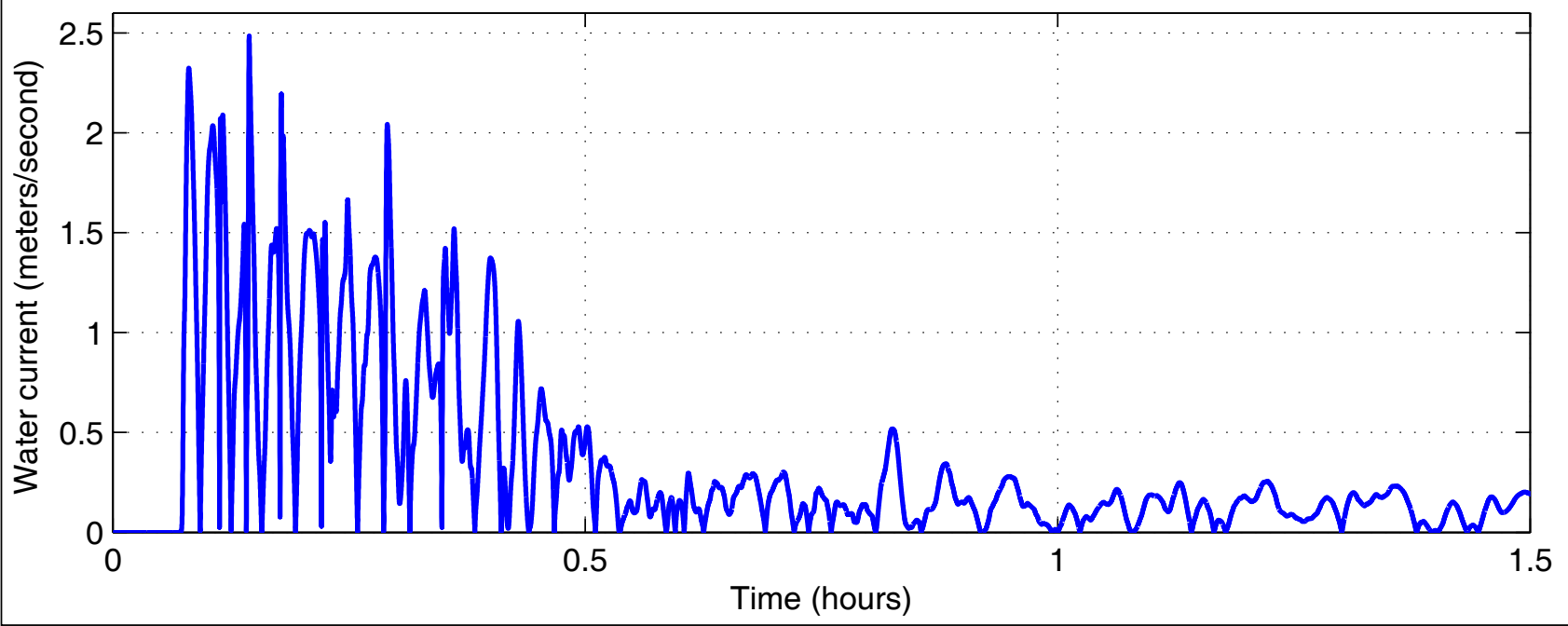

Figure C-4 (continued). Time series of the water level and velocity for scenario 10 at the locations shown in figure C-1. 


\section{APPENDIX D UNDERWATER SLIDE IN CROSS SOUND}

On July 25, 2014, at 2:54 am AKDT (10:54 UTC), an earthquake of $\mathrm{M}_{\mathrm{W}} 6.1$ occurred near Palma Bay in southeastern Alaska (fig. D-1). According to the Alaska Earthquake Center event page (http://www.aeic.alaska.edu/quakes/palma_ bay_20140725.html), it occurred at a depth of $10 \mathrm{~km}$ ( $6 \mathrm{mi}$ ) and was $42 \mathrm{~km}$ (26 mi) west-northwest of Elfin Cove, 133 km (83 mi) southwest of Haines, and $150 \mathrm{~km}(94 \mathrm{mi})$ west of Juneau. Less than one minute before the earthquake , the area experienced a magnitude 5.4 foreshock in the same location. The largest aftershock, 3 minutes after the main shock, measured magnitude 4.6. This earthquake was felt widely throughout southeastern Alaska and Yukon Territory communities, but no cases of structural damage were reported. Maximum intensity of shaking, IV-light, was reported in Elfin Cove and Hoonah.

This event was an underwater strike-slip earthquake on the Fairweather fault (figs. 4 and D-1), which is a transform fault that extends primarily offshore along the entire southeastern Alaska coastline. This event did not generate a tsunami, due to mostly horizontal displacements of the ocean floor. However, after the earthquake, the Alaska Communications company reported a broken fiber cable in Cross Sound that resulted in the loss of the internet connection to Southeast Alaska. After investigating the fiber damage, Alaska Communications confirmed that the cut was due to a submarine landslide, likely triggered by the earthquake. According to Jeffrey Holmes (pers. commun.), supervisor of the Cable Systems and Network Monitoring Group, the damaged fiber was deeply buried beneath the slide debris, requiring the repair team to cut the existing cable on both slides of the slide and reroute a new cable around the slide (fig. D-2).

Although an exact origin for the submarine landslide responsible for the fiber cable break has not been identified, we infer that a slope failure along the steep underwater slopes northwest of the cable break area caused the damage. A high-resolution bathymetry survey of the area would be needed to identify the source of the landslide and estimate its volume. This landslide event supports the hypothesis that the Cross Sound area is prone to underwater slides that could be triggered even by moderate earthquakes, and provides additional support for the potential occurrence of submarine landslide-generated waves in southeastern Alaska. 


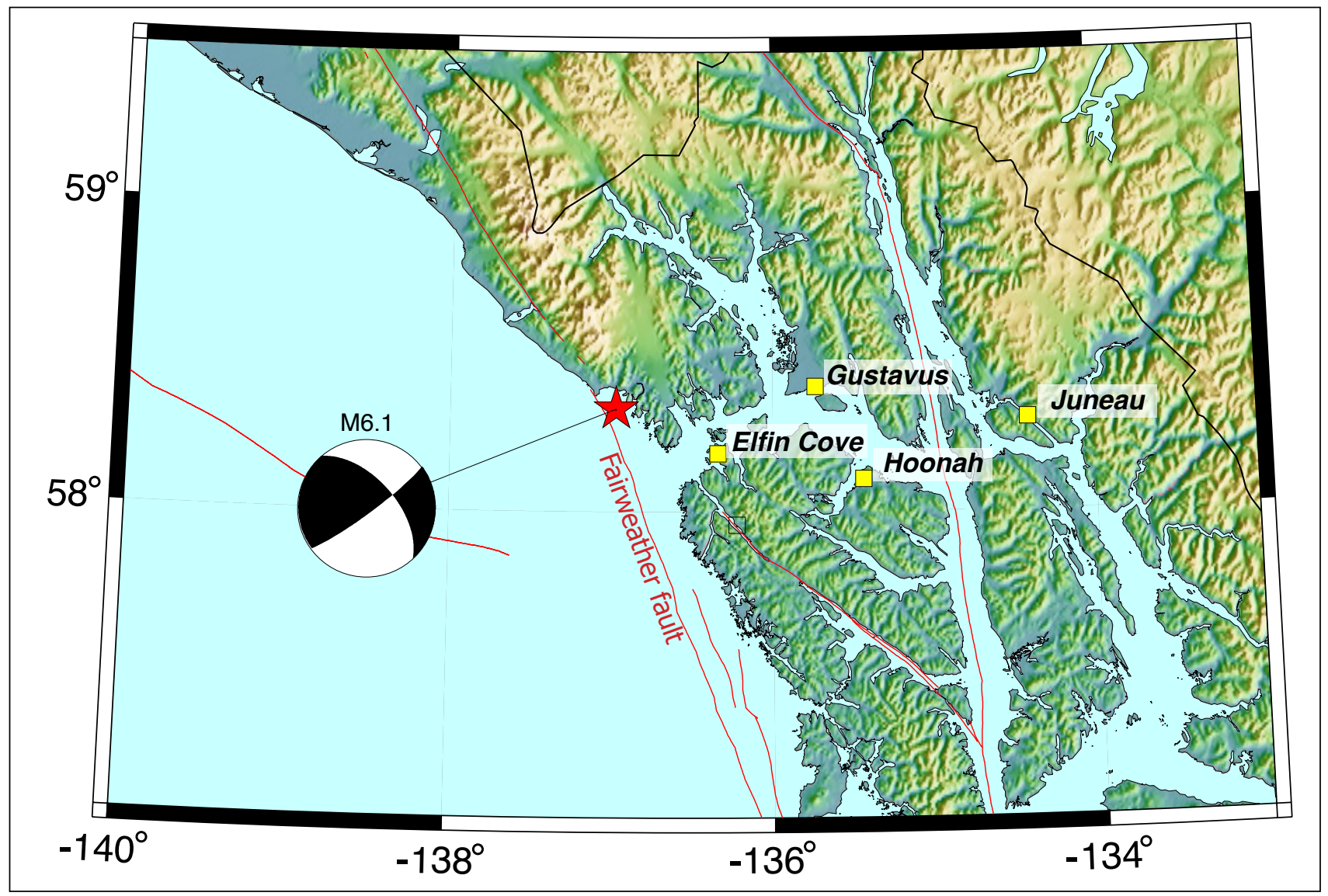

Figure D-1. Source mechanism and epicenter (red star) of the $M_{w} 6.1$ July 25, 2014, earthquake in southeastern Alaska. 


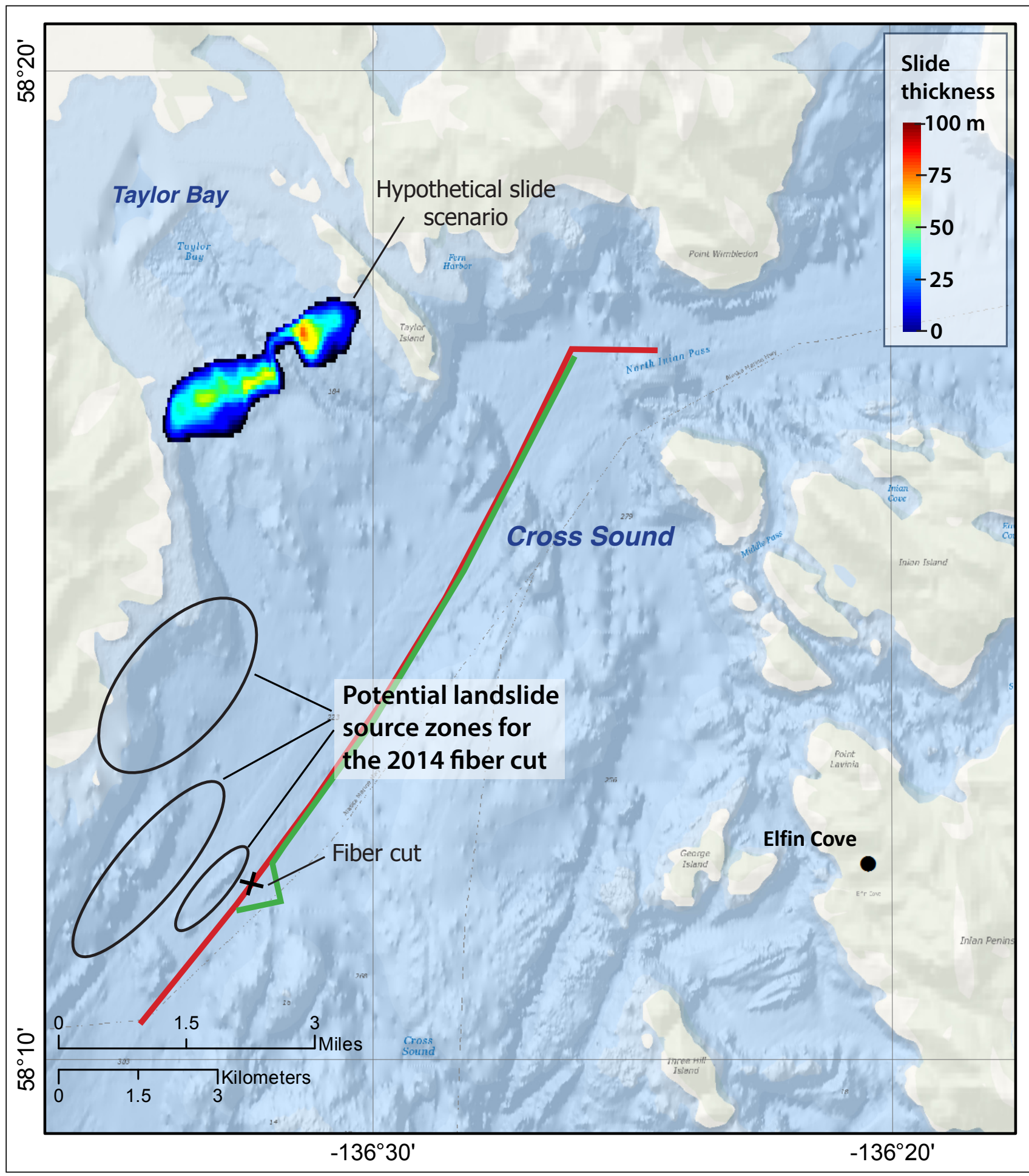

Figure D-2. Location of the Alaska Communications fiber cable cut (black cross) in Cross Sound in relation to the community of Elfin Cove and the hypothetical landslide scenario in Taylor Bay. Red line is the original cable route; green line is the repaired cable route. 